UNIVERSIDADE ESTADUAL PAULISTA "JÚLIO DE MESQUITA FILHO" FACULDADE DE MEDICINA

CAMPUS DE BOTUCATU

\title{
POTENCIAL TOXICOGENÔMICO E CITOTÓXICO DOS ANESTÉSICOS PROPOFOL E ISOFLURANO EM INDIVÍDUOS SUBMETIDOS A PROCEDIMENTOS CIRÚRGICOS
}

\section{Mariana Gobbo Braz}

Tese apresentada ao Programa de
Pós-Graduação em Patologia da Faculdade de
Medicina de Botucatu, Universidade Estadual
Paulista - UNESP para obtenção do título de Doutor
em Patologia

BOTUCATU - SP 


\author{
UNIVERSIDADE ESTADUAL PAULISTA “JÚLIO DE MESQUITA FILHO” \\ FACULDADE DE MEDICINA \\ CAMPUS DE BOTUCATU
}

\title{
POTENCIAL TOXICOGENÔMICO E CITOTÓXICO DOS ANESTÉSICOS PROPOFOL E ISOFLURANO EM INDIVÍDUOS SUBMETIDOS A PROCEDIMENTOS CIRÚRGICOS
}

\author{
Mariana Gobbo Braz
}

Daisy Maria Fávero Salvadori

Orientadora

\begin{abstract}
Tese apresentada ao Programa de Pós-Graduação em Patologia da Faculdade de Medicina de Botucatu, Universidade Estadual Paulista - UNESP para obtenção do título de Doutor em Patologia
\end{abstract}

BOTUCATU - SP 
FICHA CATALOGRÁFICA ELABORADA PELA SEÇÃO TÉCNICA DE AQUISIÇÃO E TRATAMENTO DA INFORMAÇÃO

DIVISÃO TÉCNICA DE BIBLIOTECA E DOCUMENTAÇÃO - CAMPUS DE BOTUCATU - UNESP BIBLIOTECÁRIA RESPONSÁVEL: Selma Maria de Jesus

\section{Braz, Mariana Gobbo.}

Potencial toxicogenômico e citotóxico dos anestésicos propofol e isoflurano em indivíduos submetidos a procedimentos cirúrgicos / Mariana Gobbo Braz.

- Botucatu, 2010.

Tese (doutorado) - Faculdade de Medicina de Botucatu, Universidade Estadual Paulista, 2010

Orientadora: Daisy Maria Fávero Salvadori Assunto CAPES: 40102130

\section{Anestesia - Efeitos fisiológicos 1. Patologia cirúrgica}

Palavras-chave: Apoptose; Expressão gênica; Genotoxicidade; Isoflurano; 
“O sucesso não é o final e o fracasso não é fatal: o que conta é a coragem para seguir em frente."

(Winston Churchill) 


\section{DEDICATÓRIA}

A Deus,

Pela minha existência e por seu infinito amor. Agradeço pela família que tenho e pelas pessoas especiais que estão de alguma maneira, presentes em minha vida.

À minha família,

Que é a minha fortaleza.

O meu eterno agradecimento aos meus pais José Reinaldo e Fátima, pelo amor incondicional, educação, incentivo, apoio, carinho e fé. Amo vocês.

Aos meus queridos irmãos Leandro, Fabiana e Danilo, e minha cunhada Rúbia, por me incentivarem e estarem sempre dividindo todos os momentos. Tenho carinho muito especial por vocês.

Aos meus tios, tias e primos, obrigada pelo carinho.

Aos fofos Neon e Nenê por existirem.

Dedico este trabalho à minha querida família e aos meus amigos.

"A cada dia que vivo mais me convenço de que o desperdício da vida está no amor que não damos, nas forças que não usamos, na prudência egoísta que nada arrisca, e que, esquivando-nos do sofrimento, perdemos também a felicidade."

(Carlos Drummond de Andrade) 


\title{
AGRADECIMENTOS
}

Agradeço a todos que, de alguma forma, colaboraram para a realização deste trabalho e, em particular:

\begin{abstract}
À Daisy,
Por ser essa pessoa que tanto admiro. Meus agradecimentos pela orientação, pelo profissionalismo e pelos ensinamentos, e por sempre me estimular e incentivar a enfrentar os desafios. Sou grata pela oportunidade dada para participação em congressos internacionais e realização de estágio no exterior. Obrigada também pelos bons momentos compartilhados, juntamente com o pessoal do laboratório.
\end{abstract}

À Fundação de Amparo à Pesquisa do Estado de São Paulo (FAPESP), pela bolsa e auxílio concedidos.

\section{À Dra Denise Fecchio,}

Pela gentileza e confiança em permitir que eu fizesse parte dos experimentos no laboratório de Inflamação, no Departamento de Patologia, FMB-UNESP. Obrigada pelo carinho.

\footnotetext{
À Dra Maria Inês de Moura Campos Pardini,

Por ter aberto as portas do laboratório de Biologia Molecular, no Hemocentro da FMBUNESP, para realização de parte dos experimentos e estar sempre disposta a ajudar. Obrigada pelos ensinamentos.
}

À Marina Mazoti,

Pela convivência e rotina dos experimentos. Obrigada pela valiosa ajuda e amizade.

À Juliana Giacobino,

Por ter me ajudado nos experimentos e análises do teste do cometa.

À Juliana Capannacci e Adriana Ferrasi,

Pela disponibilidade e ajuda na área de biologia molecular. 
Ao meu pai e ao meu irmão Leandro,

Pelo empenho e dedicação, e pelas coletas realizadas.

A todos os pacientes, que doaram seu sangue pela ciência.

Aos docentes e residentes do Departamento de Anestesiologia da FMB-UNESP, em especial, os residentes Eduardo Sakai e Matheus Pinotti, pela dedicação e entrevistas com os pacientes.

Aos Drs José Vicente Tagliarini e Norimar Dias, do Departamento de Oftalmologia, Otorrinolaringologia e Cirurgia de Cabeça e Pescoço da FMB-UNESP, pelas cirurgias realizadas.

Às colegas e funcionárias Márjorie Golim e Valéria da Silva, do Laboratório de Citometria de Fluxo do Hemocentro da FMB-UNESP, pela compreensão e convivência.

Às funcionárias e colegas Dra Paula Hokama, Elizabethe Garcia, Rejane Groto, Camila Verdichio, Patrícia Levada, Chiara Legnaro e Juliana Padovani, do Laboratório de Biologia Molecular do Hemocentro da FMB- UNESP, pela agradável convivência.

À Profa Lídia de Carvalho e ao doutorando João Paulo Marcondes, pelas análises estatísticas.

À Selma de Jesus e Rosemary da Silva, bibliotecárias da UNESP-Botucatu, pela realização da ficha catalográfica e orientação das referências, respectivamente.

À Janete Silva, Andrea Devidé, Lílian Nunes, Regina Spadin e Nathanael Salles, da seção de Pós-Graduação, e à Vânia Soler, secretária da Pós-Graduação em Patologia, da FMB-UNESP, pelo apoio e por sempre estarem dispostos a ajudar.

À Cristina Dorico, funcionária do Departamento de Patologia, da FMB-UNESP, pela ajuda, amizade e carinho.

Ao Luciano Donini, funcionário do Departamento de Patologia, da FMB-UNESP, por todos os favores gentilmente prestados. 
Ao Dr Richard Paules, que me deu a oportunidade de realizar estágio em seu laboratório e com o grupo de microarray no National Institute of Environmental and Health Sciences (NIH - Research Triangle Park, EUA) e Cindy Innes, pelo profissionalismo, convivência e ensinamentos.

Aos funcionários e colegas que convivi do Laboratório TOXICAM: Paulo, Mara, Carla, Tony, Merielen, Alexandre, Meire, João, Marize, Viviane, Bruno, Ana Paula, Gabrielli, Bianca, e a todos os pós-graduandos da Patologia, pelo convívio.

Aos colegas e amigos do Laboratório de Toxicogenômica e Nutrigenômica: Juliana Dorico, Camila Gobette, Kamila Kihara, Luciana Feliciano, Magaly Monteiro, Rodrigo de Lima, Danielle de Almeida; Renato Prado, Elaine de Camargo, João Paulo Marcondes e Glenda da Silva, pela convivência, aprendizagem, companheirismo; dificuldades compartilhadas, conquistas, congressos e viagens, e à amizade sincera. Vocês são especiais.

\section{À Shadia Ihlaseh,}

Pela amizade e ensinamentos, convivência nos EUA e ajuda nas análises de expressão gênica.

Aos colegas e amigos de Botucatu, e da faculdade (XXXVI turma de Biomedicina-UNESPBotucatu): Juliana dos Santos, Stella Freitas, Lina Ito, Mariana Greatti, Thaís Carvalho, Nahomi Yamaki, Priscilla Negraes, Renata da Silva; e em especial, Willian Luna, Flávia Chaves, Fernanda Inoue e Camila Marconi, pela convivência, alegrias e sofrimentos repartidos e; pelo carinho, compreensão, viagens, conselhos, risos e choros, obrigada por vocês fazerem parte da minha vida. 


\section{SUMÁRIO}

1.REVISÃO DA LITERATURA

2.OBJETIVOS

\section{MANUSCRITOS PARA PUBLICAÇÃO}

3.1-Toxicogenomic and cytotoxic effects of the inhalation

anaesthetic isoflurane in patients undergoing elective surgery

3.2-Efeito genotóxico, citotóxico e toxicogenômico da anestesia

intravenosa total com propofol em pacientes sob cirurgia

\section{ARTIGO PUBLICADO}

4.1-Evaluation of DNA damage and lipoperoxidation of propofol

in patients undergoing elective surgery

5.CONCLUSÕES

6.REFERÊNCIAS 


\section{REVISÃO DA LITERATURA}

\subsection{Anestésicos e Genotoxicidade}

O DNA está continuamente exposto a uma variedade de agentes genotóxicos exógenos e endógenos que podem alterar sua estrutura e modificar suas funções. Dentre os agentes exógenos, os anestésicos inalatórios têm atraído especial atenção em virtude da sua ampla utilização (Sardas et al., 1998a; Jaloszynski et al., 1999; Alleva et al., 2003; Szyfter et al., 2004).

$\mathrm{O}$ anestésico halogenado isoflurano (ISF) tem sido um dos mais empregados na anestesia geral (Figura 1) e a sua introdução na prática clínica representou grande avanço para a anestesia inalatória, devido sua baixa taxa de metabolização e baixo coeficiente de partição sangue-gás, o que possibilitou a diminuição do tempo de indução e de recuperação anestésica (Eger, 1994). O ISF (2-cloro-2-(difluorometoxi)-1,1,1-trifluoro-etano) é metabolizado pela enzima CYP2E1, gerando um intermediário que se decompõe em metabólito reativo (TFA$\mathrm{Cl}$ ), ou no intermediário trifluoracetil éster (Martin Jr \& Njoku, 2005a). Por ser um éter halogenado ( $\alpha$-haloéter), esse anestésico tem estrutura semelhante a de alguns carcinógenos químicos não anestésicos, como, por exemplo, o clorometil metil éter (Martin Jr \& Njoku, 2005b).

Os primeiros resultados sobre o potencial mutagênico e carcinogênico do ISF foram controversos. Em 1976, Corbett sugeriu que o ISF era capaz de induzir tumor hepático em ratos, o que não foi confirmado por estudo conduzido por Eger et al. (1978). O ISF não foi apontado como agente mutagênico pelo teste de Ames na linhagem TA 1535, com ou sem metabolização, e pelo ensaio recessivo letal ligado ao sexo em Drosophila melanogaster (Baden et al, 1977; Kundomal \& Baden, 1985). Os anestésicos voláteis não são classificáveis (Grupo 3) quanto a sua carcinogenicidade tanto para animais quanto para o homem, pela International Agency for Research on Cancer (IARC, 1987).

Em 1999, Jaloszynski et al. detectaram o potencial genotóxico do ISF, quando utilizaram o teste do cometa em linfócitos humanos expostos, in vitro, a concentrações de 1 mM. O aumento de lesões genotóxicas em linfócitos de pacientes submetidos a cirurgias invasivas e anestesiados com o ISF foi também reportado por Sardas et al. (1998b) e por Karabiyik et al. (2001). Resultado semelhante foi descrito por Kim et al. (2006) que, utilizando o teste do cometa, observaram aumento de danos no DNA de linfócitos, baço, medula óssea, fígado e cérebro de ratos expostos a 1\% de ISF, por 30 ou $60 \mathrm{~min}$. 
Os mecanismos pelos quais os anestésicos inalatórios podem induzir lesões no DNA não são completamente conhecidos. Sugere-se, no entanto, que esses compostos podem ser genotóxicos por reagirem diretamente com a molécula do DNA, alquilando a posição N7 das purinas, ou pela formação de metabólitos reativos, ou, ainda, pela liberação de espécies reativas de oxigênio (ROS) (Jaloszynski et al., 1999).

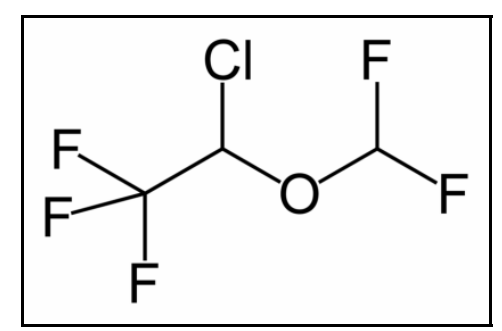

Figura 1 - Estrutura química do isoflurano

Dos anestésicos venosos, o propofol (PF) tem sido o mais utilizado para a anestesia geral. Esse composto foi introduzido na prática clínica há, aproximadamente, 30 anos, e tem como características a rápida ação, a curta duração do efeito e o perfil farmacocinético apropriado para a sedação prolongada e para uso em infusão contínua (Shafer et al., 1988). O PF (2,6bis-[1-metiletil]fenol) ou (2,6-diisopropilfenol) é rapidamente metabolizado no fígado por conjugação (UGT) com glicuronídeo e sulfato, produzindo compostos solúveis em água, os quais são excretados por via renal (Simons et al., 1985).

Esse anestésico possui em sua estrutura química um grupo fenólico (Figura 2) semelhante ao hidroxitolueno butilado e ao $\alpha$-tocoferol (vitamina E), potentes agentes antioxidantes (Tsuchiya et al., 2002). Arts et al. (1995) relataram que o PF é capaz de inibir a peroxidação lipídica plasmática nas concentrações normalmente utilizadas na prática anestésica. Contudo, alguns autores acreditam que o PF só tem atividade antioxidante quando utilizado em altas concentrações, maiores do que as que são normalmente utilizadas na prática clínica (Green et al., 1994). Em cirurgia coronariana com circulação extracorpórea, por exemplo, o PF foi efetivo em atenuar a lipoperoxidação em célula do tecido atrial durante lesão de isquemia e reperfusão (Sayin et al., 2002).

No que se refere ao possível potencial toxicogenético do $\mathrm{PF}$, não foi observado aumento de trocas entre cromátides irmãs (TCI) em linfócitos de crianças, nem de aberrações 
cromossômicas $(\mathrm{AC})$ em pacientes submetidos a cirurgia cardíaca sob anestesia com esse composto (Krause et al., 2003; Karahalil et al., 2005). Recentemente, nosso grupo de pesquisa publicou o primeiro estudo que utilizou o teste do cometa para avaliar danos no DNA em células de sangue periférico de pacientes anestesiados com o PF, no qual não foi detectado potencial genotóxico (Braz et al., 2009).

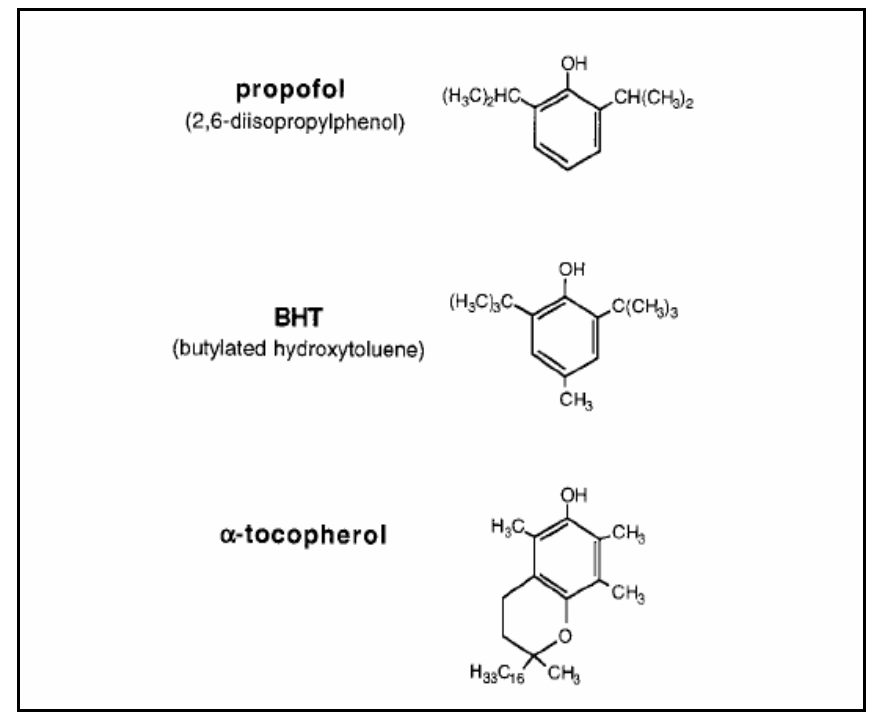

Figura 2 - Estruturas químicas do propofol, do hidroxitolueno butilado e do $\alpha$-tocoferol

\subsection{Anestésicos, Cirurgia e Sistema Imunológico}

Sabe-se que o organismo, em resposta ao procedimento cirúrgico, reage por meio de estresse causado por alterações hormonais, metabólicas, hematológicas e imunológicas (Hall \& Ali, 1998). O estresse não ocorre apenas devido ao trauma do ato cirúrgico, mas, também, pode estar relacionado ao agente anestésico (Salo et al., 1997).

A anestesia geral e o estresse cirúrgico são considerados como indutores de imunossupressão, por atuarem sobre o sistema imunológico, ou por ativarem o eixo hipotálamo-pituitária-adrenal (HPA) do sistema nervoso autônomo simpático. Durante situações de estresse, como cirurgia ou dor pós-operatória, os fármacos anestésicos podem estar relacionados à imunossupressão no período perioperatório, em virtude da ação direta sobre a imunidade celular, uma vez que podem alterar funções de células imunocompetentes e a expressão de genes responsáveis pela produção de mediadores inflamatórios (Kurosawa \& Kato, 2008). Considerando-se que a imunossupressão pós-cirúrgica pode aumentar a possibilidade de o paciente apresentar infecções no pós-operatório, a identificação de 
biomarcadores moleculares relacionados ao sistema imunológico poderia representar alvos terapêuticos potenciais na imunomodulação perioperatória (Sylla et al., 2006).

Por conta da menor incisão, a cirurgia minimamente invasiva, como a realizada por laparoscopia, é menos traumática e parece estar associada a menor resposta inflamatória quando comparada à cirurgia aberta (Cheng, 2005). O perfil das citocinas envolvidas no processo inflamatório também parece ser diferente dependendo do tipo de anestesia e do anestésico empregado (El Azab et al., 2002). Em geral, indivíduos saudáveis que são submetidos a cirurgia eletiva não invasiva podem "superar" o quadro inflamatório, enquanto os pacientes imunodeprimidos, os pacientes em estado grave com sepse e os que são submetidos a cirurgia coronariana podem, facilmente, apresentar alteração imunológica, o que pode contribuir para a má cicatrização, infecções pós-operatórias, síndrome da resposta inflamatória sistêmica (SIRS), falência múltipla dos órgãos, entre outras complicações (Cheng, 2005).

Há evidências de que a disfunção do sistema imunológico após cirurgias leva a profunda, mas transitória, depleção de todos os tipos de linfócitos (Espanol et al., 1974). Embora não se conheça o mecanismo responsável pela diminuição dessas células, acredita-se que seja por apoptose (Oka et al., 1996). Segundo Matsuoka et al. (2001), os anestésicos inalatórios, em associação com o estresse cirúrgico, podem causar linfocitopenia por apoptose via caspase 3. A cirurgia, ao elevar o número de linfócitos T helper 2 (Th2) e diminuir o de linfócitos $\mathrm{T}$ helper 1 (Th1), causa diminuição na relação Th1/Th2. Já foi relatada, por exemplo, a redução significativa da razão Th1/Th2 após anestesia com o ISF, mas não com o PF (Inada et al., 2004). Por outro lado, foi observado aumento de apoptose em estudos in vitro, como em cultura de células mononucleares e em linfócitos cultivados de pacientes que receberam anestesia com o ISF (Oka et al., 1996; Delogu et al., 2000). Estudo realizado em cães demonstrou que tanto a associação cirurgia/anestesia com ISF, como a anestesia isoladamente, resulta em quadro de linfocitopenia com aumento de apoptose, embora a associação anestesia e cirurgia tivessem induzido maior alteração no sistema imunológico (Yamada et al., 2002).

\subsection{Apoptose e Anestésicos}

A morte celular programada (MCP) é a eliminação de células de um tecido maduro, ou em formação, sem alterar a ontogênese e a sua citoarquiteura e função (Barcinski, 2004a). A forma mais comum de MCP é a apoptose, que ocorre em diversas circunstâncias e é 
controlada por uma série de genes (Ranganath \& Nagashree, 2001). A identificação da apoptose é feita pelo tipo de alteração estrutural, pelo padrão de quebra do DNA celular e pelo padrão de atividade das caspases. As mudanças morfológicas típicas são a condensação da cromatina celular, a fragmentação nuclear, a perda do controle iônico, a exposição da fosfatidilserina pela membrana, o encolhimento do citoplasma e a formação de corpos apoptóticos. Cabe ressaltar que o processo apoptótico, em contraste com a necrose, não gera resposta inflamatória (Raff, 1998).

Na apoptose, as caspases são ativadas em uma cascata proteolítica e, uma vez ativadas, algumas clivam proteínas celulares, as quais levam a rápida morte celular (Nicholson \& Thornberry, 1997). Existem duas vias de apoptose já descritas: 1) a via dos receptores de morte celular, ou via extrínseca (receptor de fator de necrose tumoral [TNF]: R-TNF e o receptor FAS: CD-95) e 2) a via da mitocôndria, ou via intrínseca (Figura 3). Na via extrínseca, os linfócitos produzem a proteína Fas ligante que se liga aos receptores Fas de superfície na célula alvo. Esta ligação recruta proteínas do citoplasma, as quais, por sua vez, recrutam a pró-caspase 8 , que é clivada em caspase e, assim ativada, inicia o processo de morte celular (Raff, 1998). Na via mitocondrial, as proteínas anti-apoptóticas B-cell lymphoma-2 (bcl-2) e bcl- $\mathrm{x}_{1}$, localizadas na membrana externa da mitocôndria, atuam inibindo a liberação do citocromo c, ou impedindo que o fator ativador de protease apoptótica (APAF1) ative a pró-caspase 9 (Barcinski, 2004b). A proteína bcl-2 diminui a injúria celular inibindo a translocação do citocromo c (Kluck et al., 1997), prevenindo a liberação deletéria de cálcio do retículo endoplasmático (Foyouzi-Youssefi et al., 2000).

Em concentração clinicamente relevante (2\%), o ISF induziu não apenas apoptose em linhagem celular de neuroglioma humano, como também alterou o processamento da proteína precursora amilóide e aumentou a produção da proteína ß-amilóide, que é encontrada na doença de Alzheimer. Sugere-se que o uso desse anestésico em indivíduos idosos com maior susceptibibilidade para formação das placas ß-amilóide aumenta o risco de disfunção cognitiva pós-operatória (Xie et al, 2006). Relatos de Wei et al. (2008) sugerem que o ISF pode induzir apoptose neuronal pela liberação anormal de cálcio do retículo endoplasmático via ativação dos receptores do inositol 1,4,5-trifosfato $\left(\mathrm{IP}_{3}\right)$.

Foi relatado, também, que o ISF induz apoptose em timócitos e linfócitos T esplênicos murinos (Kurosawa et al., 1999) e em cultura de linfócitos T CD4 ${ }^{+}$(auxiliar ou helper) e $\mathrm{CD}^{+}$(citotóxico) coletados de pacientes $24 \mathrm{~h}$ após a anestesia (Delogu et al., 2000). No entanto, o PF apresentou efeito anti-apoptótico, reduziu a citotoxicidade e preveniu danos no 
DNA em cultura de astrócitos, aspectos estes relevantes para a neuroproteção durante a anestesia (Acquaviva et al., 2004). Foi observado, ainda, que em experimentos in vitro, o PF aumentou a expressão da proteína Fas e diminuiu a de bcl-2, embora não tenha induzido morte celular por apoptose em linfócitos humanos (Delogu et al., 2001a).

Delogu et al. (2001b) observaram que o ato cirúrgico, juntamente com a anestesia geral, pode levar a um acelerado processo de apoptose de neutrófilos. Esses mesmos autores associaram a apoptose às disfunções mitocondriais (aumento de ROS) nos linfócitos em cultura de pacientes submetidos a cirurgia sob anestesia geral (Delogu et al., 2001c). O aumento de apoptose em linfócitos poderia explicar o aumento da susceptibilidade dos pacientes às infecções ou quadros de sepse, que é a causa mais comum de morte decorrente de complicações após grandes procedimentos cirúrgicos (Delogu et al., 2001d).

Em modelos experimentais de isquemia e reperfusão, foi observado que os anestésicos inalatórios produzem pré-condicionamento farmacológico contra o infarto do miocárdio, e que o ISF protege os cardiomiócitos, in vitro, contra a apoptose induzida por hipóxia. Tal efeito, ocorrido pelo aumento da expressão da proteína bcl-2, demonstra que a redução da apoptose contribuiu para os efeitos cardioprotetores do anestésico (Jamnicki-Abegg et al., 2005). Foi também observado, em cultura de neurônios corticais, que o ISF protegeu contra apoptose induzida pela privação de $\mathrm{O}_{2}$ ou de glicose (Wise-Faberowski et al., 2001). Deve ser ressaltado que o ISF é considerado um agente cardio e neuroprotetor. Contudo, esse anestésico volátil pode ter ação tanto protetora quanto tóxica aos neurônios, dependendo da concentração e duração da exposição ao anestésico, além dos fatores genéticos e da vulnerabilidade do paciente (Wei et al., 2008). 


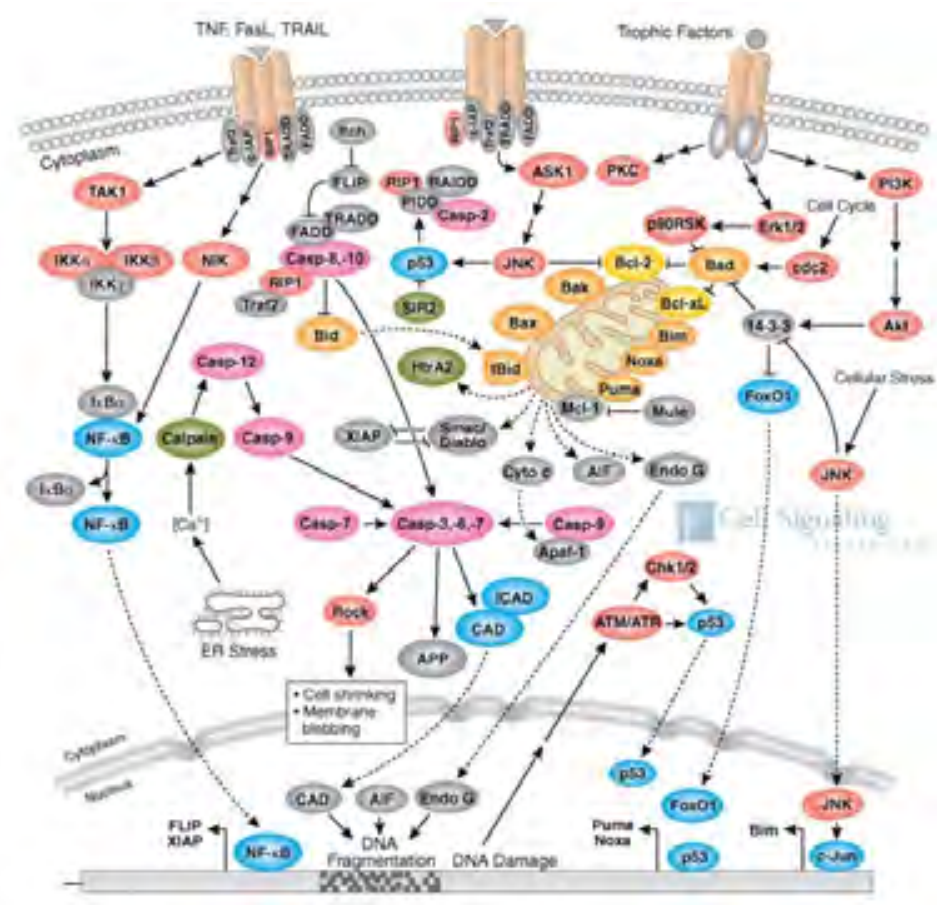

Figura 3 - Visão geral do complexo processo das vias extrínseca e intrínseca da apoptose (http://www.cellsignal.com/reference/pathway/Apoptosis Overview.html)

\subsection{Sistemas de Reparo do DNA}

Os sistemas de reparo do DNA, responsáveis pela manutenção da integridade do genoma, atuam reduzindo erros que podem ocorrer no processo de duplicação ou recombinação anômala e danos induzidos por agentes endógenos ou exógenos. Essas alterações, se não reparadas, podem interferir no metabolismo do DNA e em funções importantes, como a divisão e a regulação do ciclo celular (Benhamou \& Sarasin, 2000). Assim sendo, o reparo de danos no DNA é evento fundamental para a proteção do genoma (Hartwell \& Weinert, 1989).

Existem várias vias de reparo do DNA. Dentre elas, as mais conhecidas e estudadas são as de reparo por excisão e por recombinação. As vias de reparo por excisão podem ser classificadas de acordo com o tipo de alteração que ocorre na molécula de DNA e de como ela será removida. A via por excisão de bases (BER) repara as desaminações espontâneas, oxidações e alquilações do DNA, como também as perdas simples de bases (sítios abásicos); o reparo por excisão de nucleotídeo (NER) remove quase todo tipo de dano que pode produzir distorções importantes na dupla hélice do DNA (Heijmakers, 2001). O emparelhamento incorreto de bases durante a replicação ou recombinação, ou, ainda, de inserções ou deleções, 
são danos corrigidos pelo reparo conhecido como mismatch repair (MMR) (Harfe \& JinksRobertson, 2000).

O gene XRCCl, localizado no braço curto do cromossomo 19 (Mohrenweiser et al., 1989), codifica a proteína XRCC1 (X-ray cross-complementing group 1 protein), que está envolvida no reparo de quebras de fita simples via BER, inclusive de danos no DNA induzidos por ROS e por agentes ionizantes e alquilantes (Lei et al., 2002). O gene hOGG1, por sua vez, codifica a enzima 8-oxoguanina DNA glicosilase 1, que atua na remoção do aducto 7,8-diidro-8-oxoguanina (8oxoG ou 8-oxoGua), também pelo mecanismo de BER (Janssen et al., 2001).

Sabe-se que a expressão gênica varia em cada tecido e que a efetividade do reparo do DNA pode ser influenciada pelos diferentes polimorfismos gênicos. A isoforma Cys326 do gene $h O G G 1$, por exemplo, foi associada à maior susceptibilidade a vários tipos de câncer, dentre os quais o de esôfago e o de pulmão (Peng et al., 2003). Mo et al. (2006), por sua vez, reportaram o aumento da expressão do gene $h O G G 1$ em indivíduos expostos cronicamente ao arsênio, composto que induz danos oxidativos no DNA; aumento da expressão desse gene foi também observado em pacientes com câncer colorretal ou com leucemia aguda (Kondo et al., 2000; Zhou et al., 2007). Da mesma forma, o gene XRCC1, relacionado à instabilidade de microssatélites, também se apresentou hiperexpresso em pacientes com tumor colorretal $(\mathrm{Yu}$ et al., 2006). O aumento de RNA mensageiro (RNAm) de genes de reparo não reflete, necessariamente, aumento da capacidade de reparo de danos. Redução significativa de RNAm dos genes XRCC1 e hOGG1 foi detectada em linfócitos expostos a doses superiores a 20cGy de radiação gama (Sudprasert et al., 2006).

Não há na literatura ao nosso alcance relatos sobre a expressão de genes de reparo do DNA em indivíduos submetidos ao ato anestésico-cirúrgico.

\subsection{Técnicas para Avaliação Genotóxica, Citotóxica e Toxicogenômica}

Com a evolução dos métodos para a avaliação de citotoxicidade e genotoxicidade, tornou-se possível o estudo mais detalhado da toxicidade dos anestésicos. No entanto, apesar de ser um procedimento utilizado há anos, não se conhece, ao certo, os mecanismos moleculares associados aos efeitos da anestesia geral. Assim sendo, atualmente há grande preocupação em se conhecer e entender os reais efeitos e consequências das anestesias. 


\subsubsection{Teste do Cometa}

Rydeberg \& Johanson (1978), utilizando técnicas bioquímicas, foram os primeiros pesquisadores a quantificar diretamente os danos no DNA em células individualizadas. Estas, quando submetidas a condições levemente alcalinas, sofriam o desenrolamento parcial da molécula de DNA, tornando possível a visualização dos danos ao microscópio. Mais tarde, para aumentar a sensibilidade da técnica, Ostling \& Johanson (1984) introduziram o método de microeletroforese em lâminas com células embebidas em agarose, sob condições neutras. Em 1988, o uso de condições alcalinas $(\mathrm{pH}>13)$ de eletroforese, permitiu, também, a detecção de quebras de fita única e sítios álcali-lábeis no DNA, aumentando, ainda mais, a sensibilidade do teste (Singh et al., 1988). Nessas condições, as células com frequência aumentada de quebras de fita de DNA apresentam maior migração da molécula para o ânodo, permitindo a visualização de uma "cauda" após coloração com pigmento fluorescente (Figura 4). Devido a essa aparência, a imagem resultante foi chamada de "cometa", o que levou Olive (1989) a sugerir o nome Comet Assay (teste do cometa) para identificar a metodologia também conhecida por Single Cell Gel Electrophoresis assay (SCGE).

O teste do cometa, além de detectar quebras de fita simples e dupla e sítios álcalilábeis, permite a avaliação de alterações no sistema de reparo do DNA (Tice et al., 2000; Gontijo \& Tice, 2003). Para tornar o ensaio ainda mais sensível, Collins et al. (1993) propuseram a utilização de duas enzimas bacterianas, a endonuclease III (endo III) e a formamidopirimidina DNA glicosilase (FPG), que permitem reconhecer no DNA, respectivamente, pirimidinas e purinas oxidadas. Por se tratar de um ensaio que pode ser utilizado em estudos para a detecção de agentes genotóxicos e monitoramento de populações, o teste do cometa tornou-se ferramenta importante nas avaliações dos mecanismos de mutagênese e carcinogênese. Além disso, o ensaio apresenta várias vantagens que incluem: maior sensibilidade, a possibilidade de avaliação de danos em células individualizadas, a necessidade de amostras celulares extremamente pequenas e a possibilidade de aplicação em qualquer população de células, necessitando, apenas, de células viáveis, mas não necessariamente em proliferação (Tice, 1995). Trata-se de teste simples, de baixo custo, rápido e que pode ser utilizado para avaliação de genotoxicidade tanto in vitro como in vivo. 


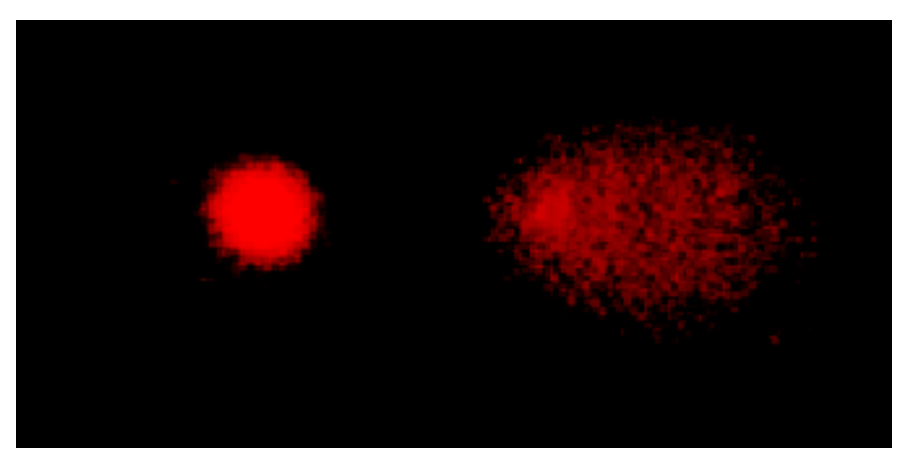

Figura 4 - Fotomicrografia de dois nucleóides (linfócitos de sangue periférico). À esquerda, nucleóide sem dano no DNA; à direita nucleóide com elevado nível de danos (“cometa”). Aumento de 400X

\subsubsection{Citometria de Fluxo}

A citometria de fluxo permite a análise rápida e objetiva de vários parâmetros de células em suspensão. Dessa forma, as células são marcadas com anticorpos monoclonais específicos ligados a fluorocromos que permitem a identificação e delimitação da população alvo da análise e a avaliação percentual dos marcadores de interesse (Faldyna et al., 2001). As vantagens da citometria incluem a alta reprodutibilidade dos dados, a rapidez e eficácia e a sua abrangente aplicabilidade, uma vez que diferencia populações celulares heterogêneas, quantifica proteínas/enzimas e citocinas, detecta proliferação celular e apoptose, entre outras.

O citômetro de fluxo pode ser constituído de vários detectores, mas o mais comum é o de três fluorescências (FL1, 2, 3). Assim, é possível realizar estudos de fenotipagem e quantificação de células por meio da conjugação a anticorpos monoclonais marcados com ficoeritrina - PE (FL2), e a avaliação da inviabilidade celular com anexina V marcada com isotiocianato de fluoresceína - FITC (FL1) e com 7-amino-actinomicina D - 7-AAD (FL3). O percentual de células marcadas com anexina quantifica células em apoptose, enquanto as células marcadas com o 7-AAD são aquelas consideradas não viáveis.

A proteína fosfatidilserina localiza-se na parte interna da membrana plasmática, mas, nos estágios iniciais da apoptose, ela se exterioriza, e como a anexina $\mathrm{V}$ tem alta afinidade pela fosfatidilserina na presença de $\mathrm{Ca}^{2+}$, é considerada importante marcador de apoptose precoce, anteriormente à fragmentação do DNA (van Engeland et al., 1998). Matsuoka et al. (2001), utilizando a citometria de fluxo, mostraram que o ISF induz apoptose em linfócitos humanos in vitro de maneira dose- e tempo-dependentes. 
Considerando que a alteração da imunidade pós-cirúrgica tem grande impacto clínico devido aos riscos de complicações, como as infecções (Delogu et al., 2001c), a quantificação de células em apoptose torna-se de grande relevância em pacientes sob anestesia e cirurgia.

\subsubsection{PCR em Tempo Real}

A Toxicogenômica é um campo da ciência que estuda os efeitos de agentes físicos, químicos e biológicos sobre a estrutura e a atividade do genoma (Aardema \& MacGregor, 2002). Mais precisamente, a Toxicogenômica integra a genômica com a toxicologia, utilizando ferramentas que permitem estudos da expressão de RNAm (transcriptoma), de proteínas (proteoma) e de metabólitos (metaboloma), em resposta a ação de estressores.

Por ser um biofluido de fácil acesso e pelo fato dos leucócitos circulantes possuírem informações sobre transcritos da primeira linha de defesa imunológica e ainda serem sentinelas para inúmeros processos patológicos (Whitney et al., 2003), o sangue periférico tornou-se alvo para os estudos toxicogenômicos. A análise da expressão gênica em leucócitos se mostrou bastante útil, por exemplo, para a identificação de biomarcadores e para a investigação da resposta do sistema imunológico em estudo sobre a inflamação (Feezor et al., 2004).

A reação em cadeia da polimerase (PCR) quantitativa em tempo real associa a metodologia de PCR a um sistema de detecção e quantificação de fluorescência produzida durante os ciclos da amplificação. A metodologia permite a amplificação, detecção e quantificação de DNA ou RNA em uma única etapa. A possibilidade de monitorar ao longo da reação a quantidade de produto formado a cada ciclo, e de quantificar esse produto durante a fase exponencial, confere maior precisão e reprodutibilidade à PCR em tempo real quando comparada à PCR convencional. A PCR em tempo real é, portanto, a metodologia de escolha para análise de expressão gênica (quantificação relativa) quando o estudo requer sensibilidade, especificidade e quantificação reprodutível de RNAm (Bustin, 2000).

Até o momento, são poucos os estudos publicados sobre o efeito toxicogenômico de anestésicos (Sakamoto et al., 2005). Na análise transcriptômica em cérebro de ratos expostos a 0,8 de concentração alveolar mínima (CAM) de ISF, por 90 min, duas vezes ao dia, em um total de 10 exposições, mudanças significativas de expressão gênica não foram observadas. Entretanto, quando os neurônios corticais primários foram expostos a 3,0 CAM de ISF, detectou-se alteração na expressão de genes relacionados ao transporte de neurotransmissores e à sinalização e estrutura celular (Pan et al., 2006). 
Foi também observado, em ratos, que após anestesia geral com o ISF ou com o PF, por período de $120 \mathrm{~min}$, houve alteração da transcrição dos immediate-early genes, induzidos pelo estresse. Esse achado sugere que os anestésicos podem não só reprimir, mas, também, estimular o sistema nervoso central. Essas alterações, no entanto, foram diferentes conforme o intervalo de tempo de exposição aos anestésicos e órgãos analisados (Hamaya et al., 2000).

Como a Toxicogenômica possibilita a predição da toxicidade antes mesmo da ocorrência do dano funcional (Zhou et al., 2009), a avaliação da ação dos anestésicos pode ter grande relevância não somente para a detecção precoce dos possíveis efeitos adversos, mas, também, para o estabelecimento de estratégias preventivas. 


\section{OBJETIVOS}

A carência e a divergência dos dados sobre o potencial toxicogenômico e citotóxico dos anestésicos, e a necessidade de esclarecimento dos mecanismos de genotoxicidade estimularam a realização do presente estudo, que foi delineado visando avaliar, em células de sangue periférico de pacientes submetidos a cirurgia eletiva, a ação genotóxica, citotóxica e toxicogenômica dos anestésicos isoflurano e propofol. Mais especificamente, os objetivos do estudo foram:

- avaliar os danos oxidativos no DNA de linfócitos de pacientes submetidos a cirurgia e anestesiados com o isoflurano ou propofol;

- fenotipar e avaliar a porcentagem de apoptose em linfócitos de pacientes submetidos a cirurgia sob anestesia geral inalatória e venosa;

- avaliar a expressão de genes relacionados ao sistema de reparo do DNA ( $h O G G 1$ e XRCC1) e à apoptose $(B C L-2)$, em sangue periférico dos pacientes submetidos a cirurgia sob anestesia com isoflurano ou propofol. 


\section{Toxicogenomic and cytotoxic effects of the inhalation anaesthetic isoflurane in patients undergoing elective surgery}

(Trabalho a ser enviado para a revista Mutagenesis)

Anaesthetics widely used in human surgery have drawn considerable attention because of their possible secondary effects. There are few studies reporting the effect of inhalation anaesthesia at the molecular level, and nothing is known about the oxidative DNA damage of isoflurane (ISF). On the other hand, surgery is often associated with a temporary perioperative immunological alteration, and some volatile anaesthetics seem to contribute to a transient lymphocytopenia after surgery. Therefore, this study aimed to evaluate the possible genotoxic effect (DNA strand breaks and oxidized bases) and the apoptosis in human lymphocytes. Furthermore, it was also investigated the expression of DNA repair (hOGG1 and XRCCl) and apoptosis (BCL-2)-related genes in blood cells of patients submitted to surgery under inhalation anaesthesia with ISF. The experimental design included 20 adult ASA physical status I patients, of both genders, submitted to elective othorhinolaryngological surgery lasting at least $120 \mathrm{~min}$. Blood samples were collected at three time points: before premedication and anaesthesia $\left(\mathrm{T}_{1}\right.$ - baseline), at $120 \mathrm{~min}$ after induction of anaesthesia $\left(\mathrm{T}_{2}\right)$, and at the first postoperative day $\left(\mathrm{T}_{3}\right)$. DNA damage was depicted by the alkaline comet assay; lymphocytes were phenotyped (helper and cytotoxic T) and apoptosis was evaluated using annexin/7-AAD by flow cytometry; gene expression was assessed by quantitative realtime RT-PCR. Results showed no statistically significant difference in the levels of DNA damage (strand breaks and oxidized purines and pyrimidines) among the three sampling times. Anaesthesia with ISF also did not increase the percentage of early or late apoptosis in both subpopulations of T lymphocytes. Besides, lower $h O G G 1$ and $B C L-2$ expressions were detected at the first postoperative day in comparison to the other previous time points $\left(\mathrm{T}_{1}\right.$ and 
$\mathrm{T}_{2}$ ). Regarding to XRCC1, it was detected a significant lower expression at $\mathrm{T}_{3}$ in relation to $\mathrm{T}_{2}$. In conclusion, ISF did not present genotoxic and cytotoxic effects on lymphocytes from patients submitted to surgery, and also did not show evident interference on the genes expression.

\section{Introduction}

DNA is continuously exposed to a variety of biological, chemical, and physical agents, which may alter its structure, modifying its function (1). Among the exogenous compounds, anaesthetic gases, commonly used in general anaesthesia procedures, have attracted attention because for their potential genotoxic effects (2-4).

Worldwide, approximately 100 million people every year are submitted to surgery, and the majority receives inhalation general anaesthetics (5). Isoflurane (ISF) and sevoflurane are the most used inhaled halogenated anaesthetics. The introduction of ISF (2-chloro-2(difluoromethoxy)-1,1,1-trifluoro-ethane) in clinical practice has represented an advance for inhalation anaesthesia, due to its low metabolism rate and low blood-gas partition coefficient, which decreases its induction and recovery times (6). The ISF is metabolized by CYP2E1 enzyme, generating an intermediate that can decompose into reactive metabolites, or the intermediate trifluoroacetyl ester. Being an ether compound, the ISF has a structure similar to that of some non-anaesthetic carcinogens, including chloromethyl methyl ether (7).

Despite genetic damage has been observed in operating room personnel exposed to trace concentrations of anaesthetic gases (8-10), the genotoxic effect of ISF is still controversial. Negative result was obtained in the Ames test using the Salmonella strain TA 1535, with and without metabolic activation (11). Nevertheless, few studies have pointed out the potential of the volatile anaesthetic inducing DNA lesions in vitro $(12)$ and in vivo $(13,2)$. The mechanisms by which this anaesthetic could induce DNA damage remain unclear. 
Whether or not ISF reacts directly with DNA, the most feasible alkali-labile modification would be alkylation at the N-7 position of purines. It may also be explained by an anaesthetic residual metabolic oxidation or reduction, giving rise to reactive products, and/or by reactive oxygen species (ROS) (12).

It is known that free radical species are capable of directly attacking DNA. ROS induce a variety of DNA lesions, including abasic (AP) sites, DNA strand breaks and oxidized bases (14). Among guanine modifications, 7,8-dihydro-8-oxoguanine (8-oxoGua) is well known, and the lesion has a distinct mutagenic potential, giving rise to GC $\rightarrow$ TA (15). Such modification in important genes, as TP53 tumor suppressor, represents a possible mechanism of tumor initiation by ROS (16). However, oxidative DNA damage is subject to repair, especially by the base excision repair (BER) system, being the genes hOGG1 (human 8oxoguanine DNA glycosylase 1) and $X R C C 1$ (X-ray cross-complementing group 1 protein) involved in this process $(17,18)$.

It has also been described evidences of immune system dysfunctions after surgery, which can lead to profound, but transient, depletion of all types of lymphocytes (19). Although the mechanism underlying the decrease of immunological cells is still not clear, it may result from lymphocyte apoptosis (20). It is known that volatile anaesthetics, in combination with surgical stress, can cause lymphocytopenia due to apoptosis via caspase-3 (21). Elevated rate of apoptosis $24 \mathrm{~h}$ after surgery has been observed in cultured $\mathrm{T}$ lymphocytes. The investigators believe that the depletion of the cells after surgery can be mediated by membrane receptor Fas, or down-regulation of Bcl-2 protein and also of p53, and mitochondrial dysfunction $(22,23)$. Furthermore, it has been reported that ISF protected cardiomyocytes and reduced apoptosis induced by hydrogen peroxide and hypoxia in rodents 
Therefore, in order to evaluate the genotoxic effect of general anaesthesia maintained with ISF, we evaluated the levels of DNA strand breaks and oxidized purine and pyrimidine, and the DNA repair capability in lymphocytes of patients before and after anaesthesia, and also 1 day after surgery. To determine whether ISF could interfere with the immune system, T lymphocytes were phenotyped and apoptosis was assessed. Furthermore, the toxicogenomic effect of the anaesthetic on DNA repair ( $h O G G 1$ and $X R C C l)$ and apoptosis $(B C L-2)$-related genes was also analyzed.

\section{Materials and methods}

\section{Subjects}

The Ethical Committee of Botucatu Medical School - UNESP (Botucatu, SP, Brazil) approved the protocol used in the present study. After signing the informed consent, all the patients answered a detailed questionnaire about their lifestyle, health status, and previous exposure to environmental pollutants. Twelve male and eight female non-smoker adult ASA (American Society of Anaesthesiologists) physical status I patients (healthy patient, with no disease other than surgical abnormality, and with no systemic disturbances), with body mass index considered normal $\left(23.5 \pm 3.5 \mathrm{~kg} / \mathrm{m}^{2}\right)$, aged from 18 to 45 years $(25.1 \pm 6.8$ years $)$, and scheduled for elective minor othorhinolaryngological surgery (15 septoplasty, 2 tympanoplasty, 2 rhinoseptoplasty and 1 amygdalectomy) lasting at least 120 minutes (140.6 $\pm 35.8 \mathrm{~min}$ ), at Botucatu Medical School Hospital, were enrolled in this study. Propofol $(160.0 \pm 46.7 \mathrm{mg})$, fentanyl $(462.0 \pm 151.3 \mu \mathrm{g})$ and rocuronium $(44.4 \pm 7.1 \mathrm{mg})$ were used during anaesthesia. 


\section{General anaesthesia procedure}

Standard clinical monitoring by Primus anaesthesia machine (Dräger Lubeck, Germany) was performed: electrocardiogram, peripheral oxygen saturation $\left(\mathrm{SpO}_{2}\right)$, noninvasive arterial pressure (systolic and diastolic), end-tidal $\mathrm{CO}_{2}\left(\mathrm{P}_{\mathrm{ET}} \mathrm{CO}_{2}\right)$ and isoflurane (ISF). Monitoring of neuromuscular blockade by train-of-four count at the adductor pollicis was also performed (TOF-Guard, Organon Teknika/Biometer, Denmark).

All patients were premedicated in the operating room with intravenous (IV) benzodiazepine midazolam ( $3 \mathrm{mg}$ ). After preoxygenation for $3 \mathrm{~min}$, anaesthesia was induced with opioid fentanyl (5 $\mu \mathrm{g} / \mathrm{kg} \mathrm{IV})$, hypnotic agent propofol (2 $\mathrm{mg} / \mathrm{kg} \mathrm{IV})$, and rocuronium bromide $(0.6 \mathrm{mg} / \mathrm{kg} \mathrm{IV})$, which is a neuromuscular blocker that was given to facilitate orotracheal intubation. The lungs were mechanically ventilated with a tidal volume of $8 \mathrm{ml}$ $\mathrm{kg}^{-1}$ of $40 \%$ oxygen $(0.8 \mathrm{l} / \mathrm{min})$ in air $(1.2 \mathrm{l} / \mathrm{min})$, and a respiratory rate of $10-12 \mathrm{breaths} / \mathrm{min}$ to maintain a $\mathrm{P}_{\mathrm{ET}} \mathrm{CO}_{2}$ concentration of $30-35 \mathrm{~mm} \mathrm{Hg}$. Volatile anaesthetic ISF at 1.0 minimum alveolar concentration (MAC) $(1.2 \%)$ was administered by inhalation. Nitrous oxide $\left(\mathrm{N}_{2} \mathrm{O}\right)$ was never used in order to avoid possible additional DNA damage and because of its immunosuppressive activity (3,25). Adequacy of anaesthesia during maintenance was assessed by haemodynamic responses, and additional doses of fentanyl $(2 \mu \mathrm{g} / \mathrm{kg})$ and rocuronium $(0.2 \mathrm{mg} / \mathrm{kg})$ were used when necessary, if the patients were judged to be inadequately anaesthetized.

Neuromuscular block was reversed with neostigmine (30 $\mu \mathrm{g} / \mathrm{kg} \mathrm{IV})$ and atropine (10 $\mu \mathrm{g} / \mathrm{kg} \mathrm{IV}$ ) at the end of surgery. Tracheal extubation was performed after full reversal of neuromuscular blockade, spontaneous ventilation, and the ability to follow verbal comments or else demonstrate purposeful unilateral movement (attempting self-extubation). Ondansetron (8 mg IV) was utilized for antiemesis. Dipyrone (1 g) and tramadol (100 mg IV) 
were used for postoperative analgesia, at the end of the surgery. If necessary, dipyrone $(1 \mathrm{~g}$ IV) was used at the first postoperative day.

\section{Blood sampling}

Venous blood samples from all patients undergoing inhalation anaesthesia were drawn at three time points: before premedication and anaesthesia ( $\mathrm{T}_{1}$ - baseline), at $120 \mathrm{~min}$ after induction of anaesthesia $\left(\mathrm{T}_{2}\right)$, and at the first postoperative day $\left(\mathrm{T}_{3}\right)$. Blood was collected in sodium heparin tubes $(10 \mathrm{ml})$, for immediately lymphocytes isolation, and in PAXgene Blood RNA Tubes (Qiagen/PreAnalytiX, Switzerland), for RNA stabilization. These tubes were kept at room temperature for $12 \mathrm{~h}$, and then placed into a freezer at $-20^{\circ} \mathrm{C}$.

\section{Chemicals}

Ethidium bromide, HEPES, and bovine serum albumin (BSA) were purchased from Sigma (USA); normal melting point (NMP) and low melting point (LMP) agarose, ethylenediamine tetraacetic acid (EDTA), blue juice, and Tris, from Invitrogen (Brazil); hydrogen peroxide $\left(\mathrm{H}_{2} \mathrm{O}_{2}\right)$ and boric acid $\left(\mathrm{H}_{3} \mathrm{BO}_{3}\right)$ from Merck (Germany); Ficoll-Paque ${ }^{\circledR}$ from GE (Sweden); annexin labeled with fluorescein isothiocyanate (FITC) and annexin V buffer, 7-amino-actinomycin D (7-AAD), phycoerythrin (PE)-labeled monoclonal antibodies anti-hCD4 ${ }^{+}$and anti-hCD8 ${ }^{+}$- from Becton Dickinson - BD (USA); endonuclease III (endo III) and formamidopyrimidine DNA glycosylase (Fpg), from New England (USA).

\section{Lymphocyte isolation}

Lymphocytes were isolated in Ficoll-Paque ${ }^{\circledR}$ gradients. Samples of peripheral blood (2 $\mathrm{ml}$ ) were mixed with $2 \mathrm{ml}$ of phosphate buffered saline (PBS), layered over $3 \mathrm{ml}$ of Ficoll, and centrifuged at $1100 \times \mathrm{g}$ for $30 \mathrm{~min}$, at room temperature. The lymphocyte layer was 
removed, mixed with $4 \mathrm{ml}$ PBS, centrifuged at $400 \times \mathrm{g}$ for $15 \mathrm{~min}$, and the cell pellet was resuspended in PBS (26). Lymphocytes were used for comet assay and flow cytometry.

\section{Alkaline comet assay}

The protocol used followed the general guidelines proposed by Singh et al.,1988 (27) and Tice et al., 1991 (28), with some modifications. Every step was carried out under indirect light. Slides were coded and blindly analyzed. Volumes of $10 \mu \mathrm{l}$ of fresh lymphocytes were added to $120 \mu \mathrm{l}$ of $0.5 \%$ low melting point agarose at $37^{\circ} \mathrm{C}$. The mixtures were layered onto slides precoated with $1.5 \%$ normal agarose, covered with a cover slip, and left for $5 \mathrm{~min}$ at $4^{\circ} \mathrm{C}$ to solidify the agarose. Afterwards, the cover slips were carefully removed and the slides immersed, overnight, into a cold lysis solution $(2.5 \mathrm{M} \mathrm{NaCl}, 100 \mathrm{mM}$ EDTA, $10 \mathrm{mM}$ Tris with $\mathrm{pH} 10,1 \%$ Triton $\mathrm{X}-100$, and $10 \%$ DMSO). To evaluate DNA oxidative damage, an extra step was carried out. Slides were washed in PBS for $5 \mathrm{~min}$, and washed again $(3 \mathrm{x}, 5$ min each) in a buffer $1 \mathrm{x}(40 \mathrm{mM}$ Hepes, $100 \mathrm{mM} \mathrm{KCl}, 0.2 \mathrm{mg} / \mathrm{ml} \mathrm{BSA}$, and $0.5 \mathrm{mM}$ EDTA with $\mathrm{pH} 8$ ). Slides were incubated at $37^{\circ} \mathrm{C}$ for $30 \mathrm{~min}$ in a moist and dry chamber, with $100 \mu 1$ of Fpg and endo III (1:1000) that recognizes oxidized purine and pyrimidine, respectively, and with $100 \mu$ l of enzyme buffer only (control). Subsequently, the slides were left for $15 \mathrm{~min}$ at $4^{\circ} \mathrm{C}$, and the cover slips were removed. Afterwards, the slides were exposed to a freshly prepared alkaline buffer ( $1 \mathrm{mM}$ EDTA, $300 \mathrm{mM} \mathrm{NaOH}$ with $\mathrm{pH}>13)$ in a horizontal electrophoresis tank. After a 40 min DNA unwinding period, electrophoresis was conducted at $25 \mathrm{~V}$ and $300 \mathrm{~mA}$, for $30 \mathrm{~min}$. Following $15 \mathrm{~min}$ neutralization with $0.4 \mathrm{M}$ Tris (pH 7.5), the slides were fixed in absolute ethanol, and stored at $4^{\circ} \mathrm{C}$.

For DNA repair activity, aliquots of lymphocytes obtained at the three time points, were treated with $\mathrm{H}_{2} \mathrm{O}_{2} 100 \mu \mathrm{M}$, for $30 \mathrm{~min}$, at $4^{\circ} \mathrm{C}$. After treatment, cells were washed twice 
with PBS, centrifuged for $4 \mathrm{~min}$ at $600 \mathrm{x} \mathrm{g}$, and incubated at $37^{\circ} \mathrm{C}$ for $30 \mathrm{~min}$. The comet assay was conducted as described above, but without the use of the enzymes.

The slides were stained with $50 \mu$ l ethidium bromide $(20 \mu \mathrm{g} / \mathrm{ml})$ and analyzed in a fluorescent microscope at 400x magnification. Images from 100 nucleoids (two replicates) per each treatment/time point/patient were scored using the Comet Assay II Image System (Perceptive Instruments, Haverhill, Suffolk, UK). Tail intensity (\% DNA in tail - TI) was used to estimate DNA damage.

\section{Phenotyping and apoptosis detection}

$\mathrm{T}$ lymphocytes phenotyping and assessment of apoptosis were performed in a FACSCalibur Flow Cytometer (BD), with three fluorescence detectors. Early apoptosis was quantified using the annexin V-FITC method, which detects the phosphatidylserine externalized in the early phases of apoptosis (annexin- $\left.\mathrm{V}^{+} / 7-\mathrm{AAD}^{-}\right)$; cells in late apoptosis (annexin- $\left.\mathrm{V}^{+} / 7-\mathrm{AAD}^{+}\right)$were also evaluated.

Freshly obtained lymphocytes were distributed into aliquots $\left(\sim 1 \times 10^{6}\right.$ cells $\left./ \mathrm{ml}\right)$, and individually incubated: one tube was mixed with isoton, a saline solution with no antibodies (autofluorescence), vortexed and incubated at room temperature (RT), in the dark, for 15 min; other aliquots, following PE-labeled monoclonal antibodies anti-CD $4^{+}$and anti-CD8 ${ }^{+}$, were phenotyped to differentiate $\mathrm{CD} 4^{+} \mathrm{T}$ cells and $\mathrm{CD} 8^{+} \mathrm{T}$ cells.

Lymphocytes were mixed with $100 \mu \mathrm{l}$ of annexin $\mathrm{V}$ binding buffer (diluted 1:10 with distilled water), $5 \mu 1$ of annexin V-FITC, $5 \mu 1$ of 7-AAD, and $10 \mu 1$ of anti-CD4 or anti-CD8, vortexed, and incubated for $15 \mathrm{~min}$ at RT in the dark. Afterwards, a $400 \mu \mathrm{l}$ aliquot of annexin $\mathrm{V}$ binding buffer $1 \mathrm{x}$ was added to each tube, samples were vortexed, and the flow cytometry analysis was performed. Gating on lymphocytes (10,000 events were acquired for each 
sample) by forward and side scatter FSC/SSC (cell size versus granulosity) for defining the target population. Data were analyzed by the Cell Quest and FACScomp Programs.

Analysis of hOGG1, XRCC1 and BCL-2 mRNA by quantitative real-time RT-PCR ( $q R T-P C R)$ RNA was isolated with the PAXgene Blood RNA Kit according to the manufacturer's protocol (Qiagen/PreAnalytiX, Switzerland), without DNAse treatment. The concentration of total RNA was determined by the spectrophotometer NanoDrop ND-1000, and each sample was assessed for purity by absorbance at 260 and $280 \mathrm{~nm}$ (A 260/280 nm between 1.9 and 2.1). Samples integrity was assessed by $1.5 \%$ agarose gel using Tris/borate/EDTA buffer (TBE). RNA was stored at $-80^{\circ} \mathrm{C}$ until reverse transcription.

RNA was reverse-transcribed (cDNA) with High Capacity cDNA Reverse Transcription kit according to the manufacturer's protocol (Applied Biosystems - ABI, USA). The reactions were firstly incubated at $25^{\circ} \mathrm{C}$ for $10 \mathrm{~min}$ and $37^{\circ} \mathrm{C}$ for $120 \mathrm{~min}$, and then, at $4^{\circ} \mathrm{C}$. Samples were placed into a freezer at $-20^{\circ} \mathrm{C}$ until PCR.

Quantitative real-time RT-PCR was performed using Taqman FAM-MGB probes and primers, ordered as inventoried from ABI for the genes hOGG1 (assay ID Hs00213454_m1), XRCC1 (assay ID Hs 00959834_m1), and BCL-2 (assay ID Hs00608023_m1), with amplicon length $82 \mathrm{bp}, 75 \mathrm{bp}$, and $81 \mathrm{bp}$, respectively, and no genomic DNA was detected. After comparing four candidate genes for the endogenous control, $\beta$-actin $(A C T B)$ was selected for this study. $h O G G 1, X R C C 1$, and $B C L-2$ mRNA concentrations were normalized by the levels of $\beta$-actin (housekeeping gene), using also the ABI primers and probes labeled at the end 5' end with FAM as a reporter dye and at the 3' end with MGB as a quencher dye.

For amplification, TaqMan Universal PCR Master mix (ABI) was used. A final $10 \mu 1$ volume was used for each reaction. Thermal cycling and real-time detection of the fluorescence were carried out in an ABI Prism 7500 FAST, using the following amplification 
parameters: denaturation at $94^{\circ} \mathrm{C}$ for $10 \mathrm{~min}$, followed by 40 cycles of $95^{\circ} \mathrm{C}$ for $15 \mathrm{~s}$, and $60^{\circ} \mathrm{C}$ for $60 \mathrm{~s}$. Negative control (no cDNA) in duplicate was added in each plate to ensure no contamination. For the control, it was used a pool of cDNA sample from healthy subjects. All controls were run simultaneously with the test samples throughout the experiments.

Cycle threshold $(\mathrm{Ct})$ values were determined as the cycle where ROX-normalized fluorescence over background was significantly above background levels. Fold induction was calculated using the formula $2^{-\Delta \Delta \mathrm{Ct}}(29)$, where $\Delta \Delta \mathrm{Ct}=$ average $\Delta \mathrm{Ct}$ (treated) - average $\Delta \mathrm{Ct}$ (control); $\Delta \mathrm{Ct}$ is the difference between $\mathrm{Ct}$ of the interested gene and $\mathrm{Ct}$ of the $\mathrm{B}$-actin. For each sample, it was determined the relative quantification (RQ) in comparison to the control samples. In the pool samples (control), RQ for $h O G G 1$ varied from 0.8 to 1.2 ; for XRCC1 from 0.8 to 1.3; and for $B C L-2$ from 0.7 to 1.1. Based on these data, genes were considered up-regulated when RQ from patients were $\geq 1.5$; down-regulation was considered when $\mathrm{RQ}<0.5$.

\section{Statistical analysis}

The non-parametric Friedman test was used to compare DNA damage, apoptosis and gene expression (data expressed as median and $1^{\text {st }}$ and $3^{\text {rd }}$ quartiles) at the three blood sampling times. When two variables were compared, the Mann-Whitney test was performed; for multiple comparisons, the Tukey test was used. Values with $\mathrm{P}<0.05$ were considered statistically significant.

\section{Results}

Inhalation anaesthesia with isoflurane did not induce DNA damage

General anaesthesia with the volatile agent ISF at 1.0 MAC did not induce DNA strand breaks in lymphocytes (tail intensity - TI), when evaluated 120 min after anaesthesia 
$\left(T_{2}\right)$, or at the first postoperative day $\left(T_{3}\right)$. Similar results were found when Fpg and endo III (TI) were used to recognize oxidized purine and pyrimidine $\left(\mathrm{T}_{2}=\mathrm{T}_{3}=\mathrm{T}_{1}\right)$. Therefore, no statistically significant genotoxic effect of ISF was detected in human lymphocytes as depicted by the alkaline comet assay (Figure 1). Contrarily, a slight (but not significant) decrease of both oxidative and non-oxidative DNA damage was detected at $\mathrm{T}_{3}$.

Hydrogen peroxide-induced DNA damage and repair capability in lymphocytes

Table I summarizes the results of DNA damage induced in vitro by $\mathrm{H}_{2} \mathrm{O}_{2}(100 \mu \mathrm{M})$ in lymphocytes sampling at three time points. Significant genotoxicity $(\mathrm{P}<0.05)$ was observed at $\mathrm{T}_{1}, \mathrm{~T}_{2}$, and $\mathrm{T}_{3}$, with no statistical difference among them. Despite of the reduction observed when lymphocytes where incubated at $37^{\circ} \mathrm{C}$, for 30 min after $\mathrm{H}_{2} \mathrm{O}_{2}$ treatment, no statistically significant difference was detected. Therefore, this data demonstrated no effective DNA repair activity in $30 \mathrm{~min}$.

\section{General anaesthesia did not induce apoptosis in Tlymphocytes}

The percentage of viable, early and late apoptotic helper T cells $\left(\mathrm{CD} 4^{+}\right)$, from all the patients, at the three sampling times, pointed out that inhalation anaesthesia did not induce apoptosis in lymphocytes (Table II). A small, but no statistically significant $(\mathrm{P}>0.05)$ decreased of early apoptosis (annexin $\left.{ }^{+} / 7-\mathrm{AAD}^{-}\right)$was visualized at the day after surgery $\left(\mathrm{T}_{3}\right)$, when compared to $T_{1}$ and $T_{2}$ (before and 120 min after induction of anaesthesia). Similar results were found for $\mathrm{CD}^{+}$(cytotoxic T) cells (Table III).

\section{Quantitative real-time $R T-P C R(q R T-P C R)$}

hOGG1 and XRCCl genes expression in the blood cells of patients undergoing general anaesthesia with isoflurane are showed in Figures 2 and 3, respectively. Significant 
down-regulation of $h O G G 1$ was observed at the first day after surgery $\left(\mathrm{T}_{3}\right)$, when compared to $\mathrm{T}_{1}$ and $\mathrm{T}_{2}$. XRCC1 also showed down-regulation at $\mathrm{T}_{3}(\mathrm{P}<0.05)$, but only in relation to $\mathrm{T}_{2}$. Similarly to $h O G G 1$, the anti-apoptotic gene $B C L-2$ was down-regulated $(\mathrm{P}<0.05)$ at the first postoperative day $\left(T_{3}\right)$ in comparison to $T_{1}$ and $T_{2}$, but no difference was detected between the first two sampling times (Figure 4). 
A

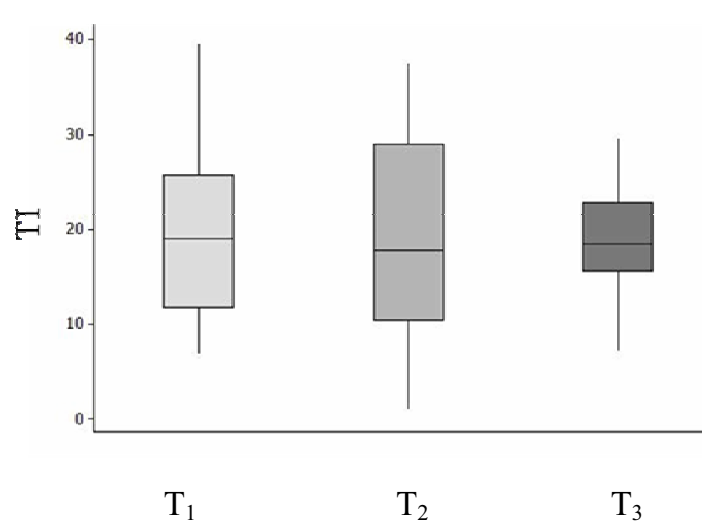

$\mathrm{T}_{1}$

$\mathrm{T}_{2}$

$\mathrm{T}_{3}$

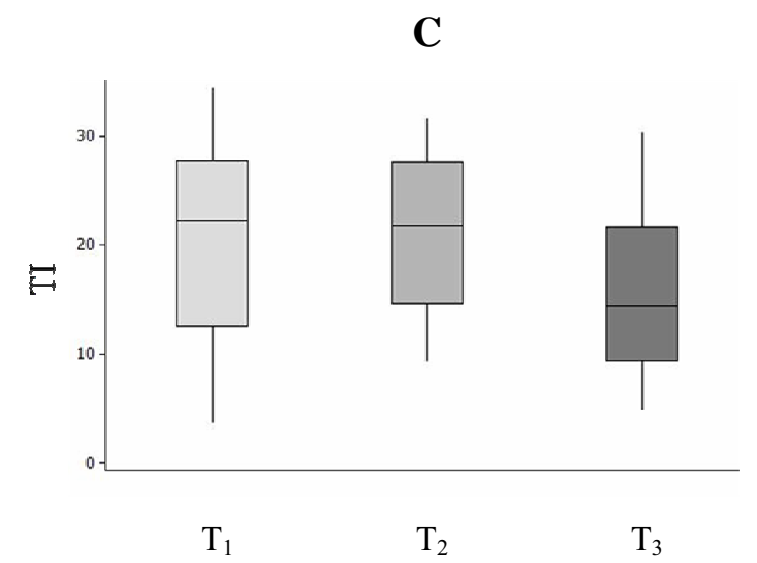

Fig. 1. DNA damage (tail intensity; TI) detected by alkaline comet assay in human lymphocytes collected before $\left(\mathrm{T}_{1}\right), 120 \mathrm{~min}$ after induction of anaesthesia $\left(\mathrm{T}_{2}\right)$, and at the first postoperative day $\left(\mathrm{T}_{3}\right)$. (A) strand breaks (B); oxidized purine; (C) oxidized pyrimidine. Data (box plot) were obtained from 20 subjects and results are expressed as median and quartiles. $\mathrm{P}>0.05$. 
Table I. DNA damage (tail intensity) and DNA repair activity in lymphocytes of patients under anaesthesia with isoflurane collected at three time points and in vitro exposed (or not) to $\mathrm{H}_{2} \mathrm{O}_{2}(100 \mu \mathrm{M})$.

\begin{tabular}{|c|c|c|c|}
\hline & \multicolumn{3}{|c|}{ Tail Intensity } \\
\hline & $\mathbf{T}_{1}$ & $\mathbf{T}_{2}$ & $\mathbf{T}_{\mathbf{3}}$ \\
\hline Lymphocytes ${ }^{1}$ & $2.6[1.3-3.8]$ & $2.6[1.5-6.7]$ & $2.4[1.4-3.5]$ \\
\hline $\mathbf{H}_{2} \mathbf{O}_{2}$ & $10.3[4.6-12.8]^{\#}$ & $6.9[2.7-7.8]^{\#}$ & $5.5[2.9-9.4]^{\#}$ \\
\hline Repair $^{2}$ & $8.2[5.8-11.6]$ & $5.4[3.2-10.9]$ & $3.1[2.0-8.7]$ \\
\hline
\end{tabular}

Table II. Percentage of viable and early and late apoptotic $\mathrm{CD}^{+} \mathrm{T}$ lymphocytes from patients undergoing anaesthesia with isoflurane.

\begin{tabular}{lccc}
\hline & \multicolumn{3}{c}{ CD4 $^{+}$T lymphocytes } \\
\cline { 2 - 4 } & $\mathbf{T}_{\mathbf{1}}$ & $\mathbf{T}_{\mathbf{2}}$ & $\mathbf{T}_{\mathbf{3}}$ \\
\hline Viable cells & $91.9[89.3-93.7]$ & $91.7[88.1-93.2]$ & $93.1[91.2-94.4]$ \\
Early apoptosis & $7.0[4.8-9.8]$ & $7.4[5.5-11.0]$ & $5.5[4.2-7.9]$ \\
Late apoptosis & $1.0[0.7-1.2]$ & $0.9[0.6-1.3]$ & $1.0[0.6-1.5]$
\end{tabular}

$\mathrm{T}_{1}$ : before anaesthesia; $\mathrm{T}_{2}$ : at $120 \mathrm{~min}$ after the induction of anaesthesia; $\mathrm{T}_{3}$ : at the first postoperative day. Data, obtained from 20 subjects, are expressed as median and quartiles. $\mathrm{P}>0.05$. 
Table III. Percentage of viable and early and late apoptotic $\mathrm{CD}^{+} \mathrm{T}$ lymphocytes from patients undergoing anaesthesia with isoflurane.

\begin{tabular}{lccc}
\hline & \multicolumn{3}{c}{ CD8 $^{+}$T lymphocytes } \\
\cline { 2 - 4 } & $\mathbf{T}_{\mathbf{1}}$ & $\mathbf{T}_{\mathbf{2}}$ & $\mathbf{T}_{\mathbf{3}}$ \\
\hline Viable cells & $91.9[87.3-95.6]$ & $92.1[88.5-94.2]$ & $93.4[91.4-95.3]$ \\
Early apoptosis & $7.9[3.9-12.1]$ & $7.0[5.4-9.9]$ & $5.3[4.2-8.1]$ \\
Late apoptosis & $0.2[0.1-0.3]$ & $0.2[0.2-0.4]$ & $0.2[0.2-0.2]$
\end{tabular}

$\mathrm{T}_{1}$ : before anaesthesia; $\mathrm{T}_{2}$ : at $120 \mathrm{~min}$ after the induction of anaesthesia; $\mathrm{T}_{3}$ : at the first postoperative day. Data, obtained from 20 subjects, are expressed as median and quartiles. $\mathrm{P}>0.05$.

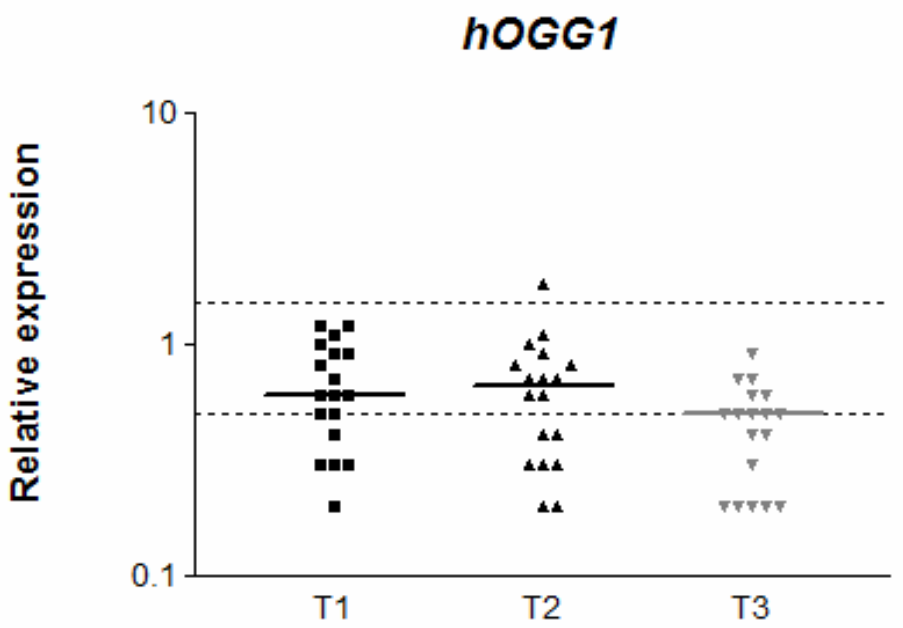

Fig. 2. Relative expression of hOGG1 DNA repair gene in blood cells of patients under general anaesthesia with isoflurane. $\mathrm{T}_{1}$ : before anaesthesia; $\mathrm{T}_{2}$ : at $120 \mathrm{~min}$ after the induction of anaesthesia; $\mathrm{T}_{3}$ : at the first postoperative day. The horizontal bars indicate median relative quantification (RQ) in each sampling time; dotted lines indicate the limits of RQ 0.5 and RQ 1.5. Data were obtained from 18 subjects. $\mathrm{P}<0.05:\left(\mathrm{T}_{1}=\mathrm{T}_{2}\right)>\mathrm{T}_{3}$. 


\section{XRCC1}

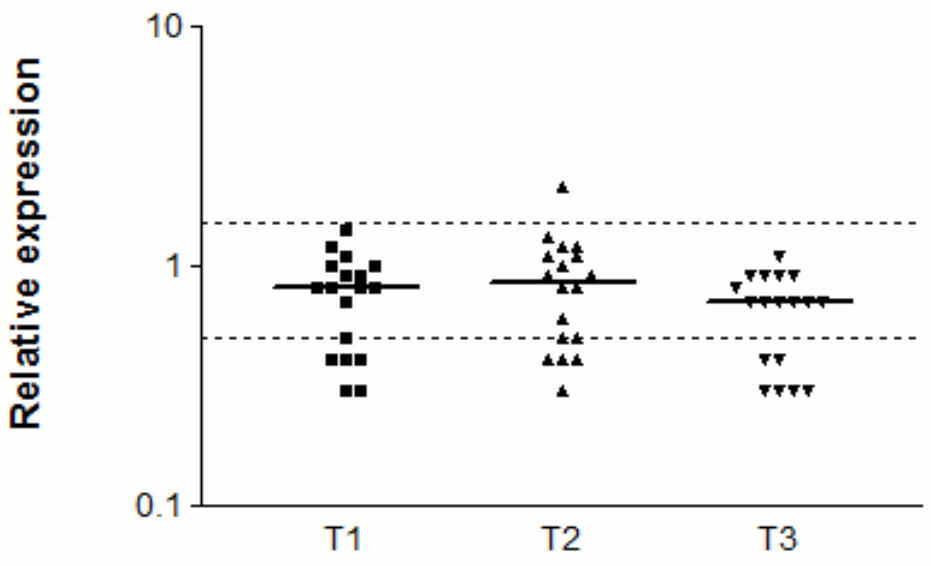

Fig. 3. Relative expression of $X R C C 1$ DNA repair gene in blood cells of patients under general anaesthesia with isoflurane. $\mathrm{T}_{1}$ : before anaesthesia; $\mathrm{T}_{2}$ : at $120 \mathrm{~min}$ after the induction of anaesthesia; $\mathrm{T}_{3}$ : at the first postoperative day. The horizontal bars indicate median relative quantification (RQ) in each sampling time; dotted lines indicate the limits of RQ 0.5 and RQ 1.5. Data were obtained from 18 subjects. $\mathrm{P}<0.05$ : $\mathrm{T}_{3}<\mathrm{T}_{2}$. 


\section{$B C L-2$}

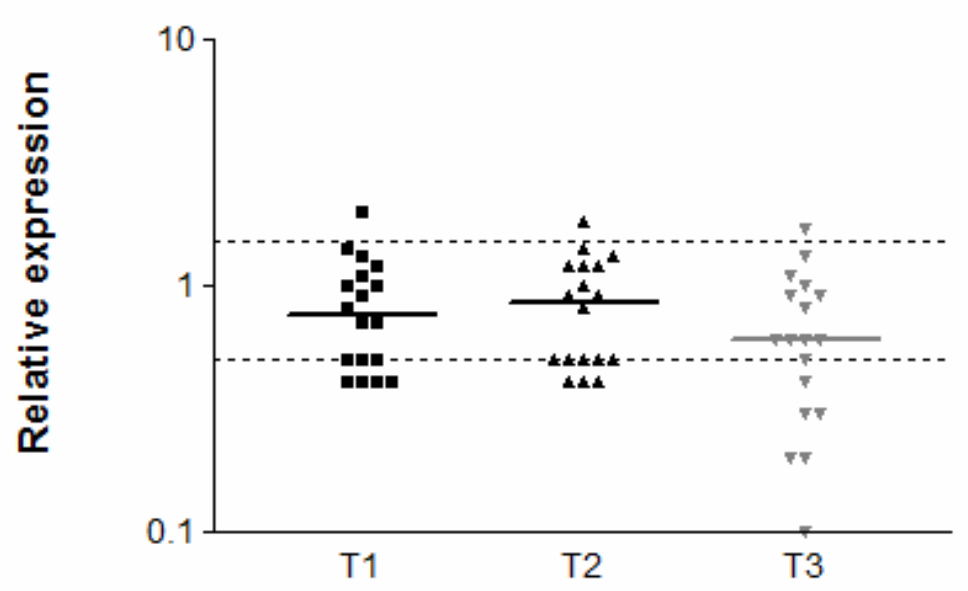

Fig. 4. Relative expression anti-apoptotic $B C L-2$ gene in blood cells of patients under general anaesthesia with isoflurane. $\mathrm{T}_{1}$ : before anaesthesia; $\mathrm{T}_{2}$ : at $120 \mathrm{~min}$ after the induction of anaesthesia; $\mathrm{T}_{3}$ : at the first postoperative day. The horizontal bars indicate median relative quantification (RQ) in each sampling time; dotted lines indicate the limits of RQ 0.5 and RQ 1.5. Data were obtained from 18 subjects. $\mathrm{P}<0.05$ : $\left(\mathrm{T}_{1}=\mathrm{T}_{2}\right)>\mathrm{T}_{3}$.

\section{Discussion}

The lack of genotoxicity observed in this study is in accordance with the negative results found when ISF was tested in Samonella typhimurium (Ames test) and in Drosophila melanogaster by the sex-linked recessive lethal assay (11,30). Similarly, the volatile anaesthetic ISF did not induce sister chromatid exchanges (SCE) in Chinese hamster ovary (CHO) and lung (CHL) cells $(31,32)$. The ability of ISF $(0.1$ to $10 \mathrm{mM})$ to reach DNA and cause strand breaks, as depicted by the comet assay, was detected in lymphocytes after in vitro treatment, but the lesions were completely repaired after 60 min (12). However, increased DNA damage has been observed in lymphocytes, bone marrow, liver, and brain of rats exposed to ISF $1 \%$ for 30 or $60 \mathrm{~min}$, with no evidence of association between the genotoxicity and lipid and protein oxidation (33). Our findings also showed that anaesthesia 
with ISF did not induce oxidative DNA damage as recognized by FPG and endo III in the comet assay. Conversely, a slightly decrease of oxidized bases, especially pyrimidines, was observed at the first postoperative day. Similar result has been reported in lymphocytes from patients submitted to inhalation anaesthesia with sevoflurane $24 \mathrm{~h}$ after surgery (3).

As far as we know, there are few studies in literature evaluating in vivo genotoxicity of ISF on human cells. Increased DNA damage has been detected in lymphocytes collected 60 min, $120 \mathrm{~min}$, and at the day after anaesthesia with ISF $\left(1 \%\right.$ and $1.5 \%$ in $\left.\mathrm{O}_{2}\right)$ in Turkish patients aged until 66 years, and classified as ASA physical status I and II (with mild systemic disease and systemic disturbance due to surgical condition), whose have been submitted to major abdominal surgeries. The data have showed that the level of DNA lesions started returning to the baseline at the third day after anaesthesia $(13,2)$. Similarly to our results, no mutagenic activity (SCE) has also been found in lymphocytes of patients before and after anaesthesia with ISF (34).

When the interference of ISF on DNA repair capability was evaluated, increased genotoxicity was detected after $\mathrm{H}_{2} \mathrm{O}_{2}$ treatment, but no reduction was detected after the 30 min period for repairing damage. This apparent inefficiency of the DNA repair system could be partially explained by the short time for repairing damage. According to Collins et al., 1997 (35) fresh lymphocytes can take several hours to repair $\mathrm{H}_{2} \mathrm{O}_{2}$-induced breaks, differently to most normal cell lines that take only few minutes. However, when we left lymphocytes incubated up to $2 \mathrm{~h}$, no repair was also observed (data not shown). No DNA repair in lymphocytes has also been detected by Visvardis et al., 1997 (36) $2 \mathrm{~h}$ after $\mathrm{H}_{2} \mathrm{O}_{2}$ treatment. It is known that, immediately after isolation, lymphocytes suffer oxidative damage from sudden exposure to high $\mathrm{O}_{2}$ concentration in atmosphere. Therefore, other explanation for the apparent slow repair of $\mathrm{H}_{2} \mathrm{O}_{2}$-induced breaks could be a continuous input of oxidative damage, and additional strand breaks, while base excision repair (BER) is proceeding (37). 
It has to be noted that healthy individuals differ in the intrinsic capability in repairing DNA damage. These variations could be due to gene polymorphisms or to alterations in the gene expression pattern (38). Therefore, in this study we evaluated the effect of ISF on the expression of two DNA repair genes in blood cells. hOGG1 removes the 8-oxoguanine (8oxoG or 8-oxoGua), a key biomarker of oxidative DNA damage that can enhance susceptibility to various diseases.

It has been reported that epigenetic events and post-translational modifications of BER enzymes may alter DNA repair gene expression (39). A possible explanation for the downregulation of hOGGl observed at the first postoperative day could be due to reduced oxidative DNA damage in that time. As our findings demonstrated, oxidative DNA damage tends to decrease at the first postoperative day. Perhaps, the stress to which patients are submitted before surgery may induce more repairable oxidative DNA damage than those possible caused by the anaesthetics. Other mechanisms, such as cell turnover, could reduce the number of DNA breaks one day after surgery (3), diminishing the recruitment of OGG1. Since it has been demonstrated that inflammatory processes can both stimulate transcription and directly inactivate some repair enzymes (39), other possible explanation for the downregulation of hOGGl would be the increase of inflammatory markers after surgery affecting gene expression. We have previously observed that patients submitted to surgery under ISF anaesthesia show high level of pro-inflammatory cytokine IL-6 $120 \mathrm{~min}$ after anaesthesia, with more pronounced increase at the first postoperative day (unpublished data). It has already been reported that inflammatory cytokines seem to inhibit DNA repair in tumor cells by a nitric oxide-dependent mechanism 1 (40).

It is known that $X R C C 1$ gene is involved in the core processes of single-strand breaks and base repairs $(41,42)$. However, an over-regulation of repair genes does not necessarily reflect increased ability for repairing damage. In lymphocytes, mRNA transcripts from 
$X R C C 1$ and $h O G G 1$ were found to be decreased in response to 20 cGy radiation (43). Several DNA repair parameters can be studied, but it should be noted that the molecular mechanisms are only partially elucidated. Repair gene polymorphisms, transcriptional activation/downregulation of specific repair genes by inflammatory processes and by certain nutrients, posttranslational modifications of repair enzymes, and other factors, must be better analyzed (39). As far as we know, there are no data in literature about DNA repair genes expression in patients submitted to anaesthesia and surgery. Herein, we did not find any change in XRCC1 expression 120 min after the anaesthesia, or at the following day, when compared to the data before anaesthesia. However, a significant down-regulation was detected after surgery when compared to the gene expression during anaesthesia.

The inflammatory stress response and the postoperative immunosuppression after inhalation anaesthesia and major surgery are characterized by peripheral $\mathrm{T}$ cell lymphopenia and leukocytosis $(44,45)$. Nevertheless, evidence regarding immunomodulatory effects of volatile anaesthetics due to apoptosis is still conflicting. ISF was able to induce dose- and time-dependent apoptosis in lymphocytes in vitro (21). However, in the same study the investigators have suggested that those results could not be extrapolated to the clinical situation because of the high concentrations (until 2.5\%) and long duration used for the in vitro treatment. It has been demonstrated that sevoflurane, and to a lesser extent ISF, induce apoptosis in human $\mathrm{CD}^{+} \mathrm{T}$ lymphocytes, by increased mitochondrial and caspase activation, but independently of death receptor signaling (46).

In the present study, we evaluated early and late apoptosis using annexin-V/7-AAD by flow cytometry. Annexin binds to phosphatidylserine, which is normally located on the inner leaflet of the plasma membrane, but it is externalized to the outer leaflet during apoptosis. The annexin- $\mathrm{V}^{+}$is an important marker of early apoptosis because it happens before DNA fragmentation (47). Two major apoptotic signaling pathways are known. The first is triggered 
by cell surface death receptors (tumor necrosis factor - TNF and FAS - CD-95 receptors) also known as extrinsic pathway, and the second is mediated through the increased permeability of the outer mitochondrial membrane or the intrinsic pathway. Lymphocytes obtained from patients anaesthetized with ISF and $\mathrm{N}_{2} \mathrm{O}$ were susceptible to Fas-mediated apoptosis, a cell surface protein, which is a member of the TNF receptor family, when cultured $2 \mathrm{~h}$ and $24 \mathrm{~h}$ after the surgery (20), but it is hard to know if this effect was caused by ISF or $\mathrm{N}_{2} \mathrm{O}$. It is also difficult to assess whether inhalation anaesthetics or surgical stress are the main cause of cell apoptosis. A study performed in dogs described that ISF anaesthesia per se or the association surgery and ISF anaesthesia reduced T cells subpopulation, although the surgery concomitant to anaesthesia impaired a greater immunocompetence (48). T cells are a critical component of cellular immunity involved in recruitment and activation of effector cell, as well as amplification of the specific immune response to pathogens (49). Thus, we have phenotyped T cells to evaluate apoptosis, and our data showed that anaesthesia with ISF did not enhance ex vivo early or late apoptosis both in $\mathrm{CD}^{+}$and $\mathrm{CD} 8^{+}$cells. Contrarily to other studies (2022), we detected a slight, but not statistically significant, decrease of apoptosis of both $\mathrm{T}$ lymphocytes at the first postoperative day. However, differently of those studies, we evaluated apoptosis in non-cultured cells from physical status I patients.

The overproduction of ROS and the disruption of the mitochondrial transmembrane potential could be involved in the apoptosis of lymphocytes at postoperative period in individuals submitted to major surgeries. Therefore, patients with a rise in apoptosis of CD $8^{+}$ seem to have increased risk for infections (22). On the other hand, a Th1/Th2 ratio has shown to be decreased after ISF anaesthesia and surgery in patients undergoing craniotomy (50).

T lymphocytes exhibit high rate of apoptosis, as well as of Fas and Fas ligand proteins, $24 \mathrm{~h}$ after ISF and $\mathrm{N}_{2} \mathrm{O}$ anaesthesia in physical status I and II patients submitted to invasive surgeries, but the baseline is reached $96 \mathrm{~h}$ after surgical procedure (22). These same authors 
have also reported a down-regulation of pro-apoptotic p53 and anti-apoptotic protein bcl-2 one day after the anaesthesia/surgery. The proto-oncogene $B C L-2$, localized in chromosome 18 , encodes an integral outer mitochondrial membrane protein that blocks apoptosis of some cells, such as lymphocytes. Depending on the cell type and differentiation stage, various transcription factors and regulatory elements have been demonstrated to regulate the expression of the BCL-2 gene (51). Similarly to Delogu et al., 2000 (22), we also observed low expression of B-cell lymphoma-2 $(B C L-2)$ transcripts at the first postoperative day. However, the meaning of the reduced expression of this gene is not clear, since we did not observe enhanced T lymphocytes apoptosis by flow cytometry. Perhaps, $B C L-2$ is repressed one day after surgery to allow damaged cells to die by apoptosis.

Aravindan et al., 2006 (52) have found reduced expression of death receptors, $B C L-2$, TP53 and ATM genes in renal cells after 2\% ISF, showing an inhibition of apoptosis in rats. These authors have suggested that ISF has anti-apoptotic activity mediated both extrinsic and intrinsic signaling pathways. It is believed that short period under anaesthesia with ISF might provide cytoprotection via preconditioning, whereas prolonged exposures produce direct cytotoxicity (53). It has been demonstrated that exposure to ISF enhance Bcl-2 protein in rodent cardiomyocytes in response to hypoxia, while $\mathrm{H}_{2} \mathrm{O}_{2}$ decreased $\mathrm{Bcl}-2$ production (24). According to the authors reduction of apoptosis, as well as decrease of myocyte necrosis contribute to the cardioprotective effects of ISF.

In conclusion, the current study demonstrated that anaesthesia with ISF did not induce oxidative DNA damage or increased percentage of $\mathrm{CD}^{+}$and $\mathrm{CD}^{+} \mathrm{T}$ apoptosis. Furthermore, no clear evidence was observed regarding the interference of this anaesthetic on expression of the DNA repair and apoptosis-genes, although a lower expression was detected at the first postoperative day in blood cells of ASA I patients submitted to surgery. 


\section{Funding}

This study was supported by Fundação de Amparo à Pesquisa do Estado de São Paulo (FAPESP; Process 06/59625-6). MGB received a PhD fellowship from FAPESP (06/588475), and JG was granted with a scholarship from Conselho Nacional de Desenvolvimento Científico e Tecnológico.

\section{Acknowledgments}

The authors are grateful to Dr Lídia Raquel de Carvalho and to MSc João Paulo de Castro Marcondes for statistical advice, and to MSc Shadia Muhammad Ihlaseh for qRT-PCR analysis advice.

Conflict of interest statement: None declared.

\section{References}

1.Halliwell,B. (1994) Free radicals and antioxidants: a personal view. Nutr. Rev., 52, 253-265.

2.Karabiyik,L., Sardas,S., Polat,U., Kocabas,N.A., Karakaya,A.E. (2001) Comparison of genotoxicity of sevoflurane and isoflurane in human lymphocytes studied in vivo using the comet assay. Mutat. Res., 492, 99-107.

3.Alleva,R., Tomasetti,M., Solenghi,M.D., Stagni,F., Gamberini,F., Bassi,A., Fornasari, P.M., Fanelli,G., Borghi,B. (2003) Lymphocyte DNA damage precedes DNA repair or cell death after orthopaedic surgery under general anaesthesia. Mutagenesis, 18, 423-428.

4.Szyfter,K., Szulc,R., Mikstacki,A., Stachecki,I., Rydzanicz,M., Jaloszynski,P. (2004) Genotoxicity of inhalation anaesthetics: DNA lesions generated by sevoflurane in vitro and in vivo. J. Appl. Genet., 45, 369-374. 
5.Eckenhoff,R.G., Johansson,J.S., Wei,H., Carnini,A., Kang,B., Wei,W., Pidikiti,R., Keller,J.M., Eckenhoff,M.F. (2004) Inhaled anesthetic enhancement of amyloid-beta oligomerization and cytotoxicity. Anesthesiology, 101, 703-709.

6.Eger,E.I.2 ${ }^{\text {nd }}$ (1994) New inhaled anesthetics. Anesthesiology, 80, 906-922.

7.Martin,Jr.J.L. and Njoku,D.B. (2005) Metabolism and toxicity of inhaled anesthetics. In Miller,R.D. (ed), Miller's Anesthesia., 6th ed. Elsevier, Pensilvania, pp. 262.

8.Bilban,M., Jakopin,C.B., Ogrinc,D. (2005) Cytogenetic tests performed on operating room personnel (the use of anaesthetic gases). Int. Arch. Occup. Environ. Health, 78, 60-64.

9.Eroglu,A., Celep,F., Erciyes,N. (2006) A comparison of sister chromatid exchanges in lymphocytes of anesthesiologists to nonanesthesiologists in the same hospital. Anesth. Analg., 102, 1573-1577.

10.Rozgaj,R., Kasuba,V., Brozovic,G., Jazbec,A. (2009) Genotoxic effects of anaesthetics in operating theatre personnel evaluated by the comet assay and micronucleus test. Int. J. Hyg. Environ. Health, 212, 11-17.

11.Baden,J.M., Kelley,M., Wharton,R.S., Hitt,B.A., Simmon,V.F., Mazze,R.I. (1977) Mutagenicity of halogenated ether anesthetics. Anesthesiology, 46, 346-350.

12.Jaloszynski,P., Kujawski,M., Wasowicz,M., Szulc,R., Szyfter,K. (1999) Genotoxicity of inhalation anesthetics halothane and isoflurane in human lymphocytes studied in vitro using the comet assay. Mutat. Res., 439, 199-206.

13.Sardas,S., Karabiyik,L., Aygun,N., Karakaya,A.E. (1998) DNA damage evaluated by the alkaline comet assay in lymphocytes of humans anaesthetized with isoflurane. Mutat. Res., 418, 1-6.

14.Epe,B. (1995) DNA damage profiles induced by oxidizing agents. Rev. Physiol. Biochem. Pharmacol., 127, 223-248. 
15.Moriya,M. (1993) Single-stranded shuttle phagemid for mutagenesis studies in mammalian cells: 8-oxoguanine in DNA induces targeted GC-TA transversions in simian kidney cells. Proc. Natl. Acad. Sci. USA, 90, 1122-1126.

16.Takahashi,T., Nau,M.M., Chiba,I. et al. (1989) p53: a frequent target for genetic abnormalities in lung cancer. Science, 246, 491-494.

17.Janssen,K., Schlink,K., Gotte,W., Hippler,B., Kaina,B., Oesch,F. (2001) DNA repair activity of 8-oxoguanine DNA glycosylase 1 (OGG1) in human lymphocytes is not dependent on genetic polymorphism Ser326/Cys326. Mutat. Res., 486, 207-216.

18.Lei,Y.C., Hwang,S.J., Chang,C.C., Kuo,H.W., Luo,J.C., Chang,M.J., Cheng,T.J. (2002) Effects on sister chromatid exchange frequency of polymorphisms in DNA repair gene XRCC1 in smokers. Mutat. Res., 519, 93-101.

19.Espanol,T., Todd,G.B., Soothill,J.F. (1974) The effect of anaesthesia on the lymphocyte response to phytohaemagglutinin. Clin. Exp. Immunol., 18, 73-79.

20.Oka,M., Hirazawa,K., Yamamoto,K., Iizuka,N., Hazama,S., Suzuki,T. Kobayashi,N. (1996) Induction of Fas-mediated apoptosis on circulating lymphocytes by surgical stress. Ann. Surg., 223, 434-440.

21.Matsuoka,H., Kurosawa,S., Horinouchi,T., Kato,M., Hashimoto,Y. (2001) Inhalation anesthetics induce apoptosis in normal peripheral lymphocytes in vitro. Anesthesiology, 95, 467-472.

22.Delogu,G., Moretti,S., Antonucci,A., Marcellini,S., Masciangelo,R., Famularo,G., Signore,L., De Simone, C. (2000) Apoptosis and surgical trauma: dysregulated expression of death and survival factors on peripheral lymphocytes. Arch. Surg., 135, 1141-1147. 
23.Delogu,G., Moretti,S., Famularo,G., Marcellini,S., Santini,G., Antonucci,A., Marandola,M., Signore,L. (2001) Mitochondrial perturbations and oxidant stress in lymphocytes from patients undergoing surgery and general anesthesia. Arch. Surg., 136, 1190-1196.

24.Jamnicki-Abegg,M., Weihrauch,D., Pagel,P.S., Kersten,J.R., Bosnjak,Z.J., Warltier,D.C., Bienengraeber,M.W. (2005) Isoflurane inhibits cardiac myocyte apoptosis during oxidative and inflammatory stress by activating Akt and enhancing Bcl-2 expression. Anesthesiology, 103, 1006-1014.

25.Schneemilch,C.E., Hachenberg,T., Ansorge,S., Ittenson,A., Bank,U. (2005) Effects of different anaesthetic agents on immune cell function in vitro. Eur. J. Anaesthesiol., 22, 616623.

26.Braz,M.G. and Favero Salvadori,D.M. (2007) Influence of endogenous and synthetic female sex hormones on human blood cells in vitro studied with comet assay. Toxicol. In Vitro, 21, 972-976.

27.Singh,N.P., Mccoy,M.T., Tice,R.R., Schneider,E.L. (1988) A simple technique for quantitation of low levels of DNA damage in individual cells. Exp. Cell Res., 175, 184-191.

28.Tice,R.R., Andrews,P.W., Hirai,O., Singh,N.P. (1991) The single cell gel (SCG) assay: an electrophoretic technique for the detection of DNA damage in individual cells. Adv. Exp. Med. Biol., 283, 157-164.

29.Livak,K.J. and Schmittgen,T.D. (2001) Analysis of relative gene expression data using real-time quantitative PCR and the $2^{-\Delta \Delta \mathrm{Ct}}$ method. Methods, 25, 402-408.

30.Kundomal,Y.R. and Baden,J.M. (1985) Mutagenicity of inhaled anesthetics in Drosophila melanogaster. Anesthesiology, 62, 305-309.

31.White,A.E., Takehisa,S., Eger,E.I. 2nd, Wolff,S., Stevens,W.C. (1979) Sister chromatid exchanges induced by inhaled anesthetics. Anesthesiology, 50, 426-430. 
32.Trudnowski,R.J., Mehta,M.P., Rucinski,M. (1987) Evaluation of the mutagenic potential of enflurane and isoflurane by sister chromatid exchange. J. Med., 18, 55-60.

33.Kim,H., Oh,E., Im,H., Mun,J., Yang,M., Khim,J.Y., Lee, E., Lim,S.H., Kong,M.H., Lee,M., Sul,D. (2006) Oxidative damages in the DNA, lipids, and proteins of rats exposed to isofluranes and alcohols. Toxicology, 220, 169-178.

34.Husum,B., Wulf,H.C., Niebuhr,E., Kyst,A., Valentin,N. (1984) Sister chromatid exchanges in lymphocytes of humans anaesthetized with isoflurane. Br. J. Anaesth., 56, 559564.

35.Collins,A.R., Dobson,V.L., Dusinská,M., Kennedy,G., Stetina,R. (1997) The comet assay: what can it really tell us? Mutat. Res., 375, 183-193.

36.Visvardis,E.E., Tassiou,A.M., Piperakis,S.M. (1997) Study of DNA damage induction and repair capacity of fresh and cryopreserved lymphocytes exposed to $\mathrm{H} 2 \mathrm{O} 2$ and gammairradiation with the alkaline comet assay. Mutat. Res., 383, 71-80.

37.Torbergsen,A.C. and Collins,A.R. (2000) Recovery of human lymphocytes from oxidative DNA damage: the apparent enhancement of DNA repair by carotenoids is probably simply an antioxidant effect. Eur. J. Nutr., 39, 80-85.

38.Cornetta,T., Festa,F., Testa,A., Cozzi,R. (2006) DNA damage repair and genetic polymorphisms: assessment of individual sensitivity and repair capacity. Int. J. Radiation Oncology Biol. Phys., 66, 537-545.

39.Tudek,B. (2007) Base excision repair modulation as a risk factor for human cancers. Mol. Aspects Med., 28, 258-275.

40.Jaiswal,M., LaRusso,N.F., Burgart,L.J., Gores,G.J. (2000) Inflammatory Cytokines Induce DNA damage and inhibit DNA repair in cholangiocarcinoma cells by a nitric oxide-dependent mechanism1. Cancer Res., 60, 184-190. 
41.Thompson,L.H., Brookman,K.W., Jones,N.J., Allen,S.A., Carrono,A.V. (1990) Molecular cloning of the human XRCC1 gene, which corrects defective DNA strand break repair and sister chromatid exchange. Mol. Cell Biol., 10, 6160-6171.

42.Kubota,Y., Nash,R.A., Klungland,A., Schar,P., Barnes,D.E., Lindahl,T. (1996) Reconstitution of DNA base excision-repair with purified human proteins: interaction between DNA polymerase beta and the XRCC1 protein. EMBO J., 15, 6662-6670.

43.Sudprasert,W., Navasumrit,P., Ruchirawat,M. (2006) Effects of low-dose gamma radiation on DNA damage, chromosomal aberration and expression of repair genes in human blood cells. Int. J. Hyg. Environ. Health., 209, 503-511.

44.Slade,M.S., Simmons,R.L., Yunis,E.,Greenberg,L.J. (1975) Immunodepression after major surgery in normal patients. Surgery, 78, 363-372.

45.Rem,J., Brandt,M.R., Kehlet,H. (1980) Prevention of postoperative lymphopenia and granulocytosis by epidural analgesia. Lancet., 1, 283-284.

46.Loop,T., Dovi-Akue,D., Frick,M., Roesslein,M., Egger,L., Humar,M., Hoetzel,A., Schmidt,R., Borner,C., Pahl,H.L., Geiger,K.K., Pannen,B.H. (2005) Volatile anesthetics induce caspase-dependent, mitochondria-mediated apoptosis in human $\mathrm{T}$ lymphocytes in vitro. Anesthesiology, 102, 1147-1157.

47.Van Engeland,M., Nieland,L.J., Ramaekers,F.C., Schutte,B., Reutelingsperger,C.P. (1998) Annexin V-affinity assay: a review on an apoptosis detection system based on phosphatidylserine exposure. Cytometry, 31, 1-9.

48.Yamada,R., Tsuchida,S., Hara,Y., Tagawa,M., Ogawa,R. (2002) Apoptotic lymphocytes induced by surgical trauma in dogs. J. Anesth., 16, 131-137.

49.Sylla,P., Nihalani,A., Whelan,R.L. (2006) Microarray analysis of the differential effects of open and laparoscopic surgery on murine splenic T-cells. Surgery, 139, 92-103. 
50.Inada,T., Yamanouchi,Y., Jomura,S., Sakamoto,S., Takahashi,M., Kambara,T., Shingu,K. (2004) Effect of propofol and isoflurane anaesthesia on the immune response to surgery. Anaesthesia, 49, 954-959.

51.Shen,Y., Iqbal,J., Huang,J.Z., Zhou,G., Chan,W.C. (2004) BCL2 protein expression parallels its mRNA level in normal and malignant B cells. Blood, 104, 2936-2939.

52.Aravindan,N., Cata,J.P., Hoffman,L., Dougherty,P.M., Riedel,K.J., Shaw,A.D. (2006) Effects of isoflurane, pentobarbital, and urethane on apoptosis and apoptotic signal transduction in rat kidney. Acta Anaesthesiol. Scand., 50, 1229-1237.

53.Wei,H., Liang,G., Yang,H., Wang,Q., Hawkins,B., Madesh,M., Wang,S., Eckenhoff,R.G. (2008) The common inhalational anaesthetic isoflurane induces apoptosis via activation of inositol 1,4,5-trisphosphate receptors. Anesthesiology, 108, 251-260. 
Efeito genotóxico, citotóxico e toxicogenômico da anestesia intravenosa total com propofol em pacientes sob cirurgia

(Trabalho a ser enviado para a revista Anesthesiology)

Introdução: Há grande preocupação com os possíveis efeitos colaterais dos anestésicos utilizados na prática anestesiológica. Embora existam evidências da ação sobre o sistema imunológico, pouco se sabe sobre o potencial genotóxico, citotóxico e toxicogenômico desses compostos em linfócitos de pacientes submetidos a cirurgia. Para melhor entender os possíveis efeitos da anestesia intravenosa total com propofol, este estudo teve por objetivo avaliar danos oxidativos no DNA e apoptose em linfócitos, e expressão de genes de reparo do DNA em pacientes submetidos a cirurgia eletiva.

Métodos: O estudo incluiu 20 pacientes com estado físico ASA I, de ambos os sexos, submetidos a cirurgia otorrinolaringológica com duração de pelo menos $120 \mathrm{~min}$, sob anestesia intravenosa total. Na indução anestésica foram utilizados o fentanil e o propofol, este inicialmente em dosagem para atingir concentração plasmática de $4 \mu \mathrm{g}$ $\mathrm{ml}^{-1}$ e, a seguir, 3 a $5 \mu \mathrm{gl}^{-1}$, até o final da cirurgia. As amostras de sangue foram coletadas antes da medicação pré-anestésica $\left(M_{1}-\right.$ controle), 120 min após a indução anestésica com propofol $\left(M_{2}\right)$ e no dia posterior ao ato anestésico-cirúrgico $\left(M_{3}\right)$. Os danos oxidativos no DNA foram avaliados pelo teste do cometa, os linfócitos foram fenotipados em $\mathrm{CD4}^{+}$e $\mathrm{CD8}^{+}$e avaliados quanto à indução de apoptose por citometria de fluxo, e as análises da expressão dos genes hOGG1 e XRCC1 foram realizadas por PCR em tempo real.

Resultados: Não foram observadas alterações nas taxas de apoptose em linfócitos T citotóxicos, e de quebras e pirimidinas oxidadas no DNA de linfócitos totais, quando comparados os três momentos de amostragem. No entanto, foi detectada redução 
significativa de purinas oxidadas no DNA de linfócitos coletados durante a cirurgia $\left(M_{2}\right)$, e diminuição de linfócitos $T$ auxiliares durante $\left(M_{2}\right)$ e um dia após o ato anestésicocirúrgico $\left(M_{3}\right)$. Foi ainda observada menor expressão do gene hOGG1 em $M_{3}(\mathrm{em}$ relação aos outros dois momentos) e do gene $X R C C 1$ em $\mathrm{M}_{3}$, mas apenas em relação a $\mathbf{M}_{2}$.

Conclusões: A anestesia intravenosa com propofol não apresentou efeito genotóxico e citotóxico em linfócitos de pacientes submetidos a cirurgia. Pelo contrário, houve evidência de redução dos níveis de purinas oxidadas no DNA e de apoptose em linfócitos $\mathrm{T} \mathrm{CD4}^{+}$. No dia seguinte ao ato cirúrgico, os genes associados ao reparo por excisão de bases do DNA apresentaram os menores níveis de expressão.

Desde a introdução dos anestésicos inalatórios e venosos na prática clínica houve a preocupação com a toxicidade orgânica desses agentes. Atualmente, vários de seus efeitos adversos são conhecidos, embora os mecanismos de toxicidade não sejam ainda bem entendidos. Os anestésicos inalatórios têm atraído especial atenção devido à sua ampla utilização e seu potencial genotóxico.$^{1-4}$ Entretanto, há poucos dados na literatura em relação aos possíveis efeitos genotóxicos e toxicogenômicos do propofol. ${ }^{5-7}$ Em estudo recente, mostramos que a anestesia venosa com o propofol não induziu danos no DNA em leucócitos de pacientes submetidos a cirurgia eletiva. ${ }^{8}$

O propofol (2,6-diisopropilfenol) foi introduzido na prática clínica há, aproximadamente, 30 anos, e tem como características a rápida ação, a curta duração do efeito e o perfil farmacocinético apropriado para a sedação prolongada e para uso em infusão contínua. ${ }^{9}$ Esse composto foi o primeiro de uma nova classe de agentes anestésicos intravenosos, os alquilfenóis, e é caracterizado pela sua estrutura fenólica semelhante ao $\alpha$-tocoferol (vitamina E). Assim, o propofol é também conhecido por sua propriedade antioxidante e como 
capturador de radicais livres. ${ }^{10-12}$ Recentemente, contudo, observamos que a anestesia venosa total com propofol, em pacientes submetidos a cirurgia eletiva, não alterou os níveis plasmáticos de malonaldeído ou malonildialdeído (MDA), produto de lipoperoxidação, e potencial biomarcador de estresse oxidativo. ${ }^{8}$

O organismo, em resposta ao procedimento cirúrgico, reage por meio de estresse causado por alterações hormonais, metabólicas, hematológicas e imunológicas. ${ }^{13} \mathrm{O}$ ato cirúrgico pode intensificar o quadro de estresse oxidativo pela geração de espécies reativas de oxigênio (ROS), que interagem com macromoléculas como proteínas, lipídios e bases do DNA, e que podem levar a morte celular por apoptose ou necrose, ou enfraquecer o sistema de defesa biológico. ${ }^{14,15}$ Contudo, o estresse oxidativo não ocorre apenas devido ao trauma do ato cirúrgico, mas, também, pode estar relacionado ao agente anestésico. ${ }^{16}$ Há relatos de disfunção do sistema imunológico após cirurgias, principalmente sob anestesia inalatória, levando a profunda, mas transitória, depleção de todos os tipos de linfócitos. No entanto, pouco se sabe a respeito da anestesia venosa. ${ }^{17,18}$ Inada et al. $(2004)^{19}$ relataram a redução da razão dos linfócitos $\mathrm{T}$ helper Th1/Th2 após a anestesia com o isoflurano, mas não com o propofol. Foi observado que o propofol apresentou efeito anti-apoptótico e reduziu a citotoxicidade in vitro. ${ }^{6}$

Diante dos dados ainda pouco conclusivos sobre o potencial genotóxico, citotóxico e toxicogenômico do propofol, o presente estudo teve como objetivos avaliar as lesões oxidativas no DNA, a apoptose em linfócitos e a expressão de genes relacionados ao reparo de DNA em sangue periférico de pacientes submetidos a cirurgia eletiva. 


\section{Pacientes e Método}

\section{Casuística}

A pesquisa foi registrada no Clinical Trials sob número NCT00854178. Após a aprovação do estudo pelo Comitê de Ética em Pesquisa da Faculdade de Medicina de Botucatu, o estudo foi realizado com 20 pacientes de ambos os sexos, com estado físico classificado pela Sociedade Americana de Anestesiologia como ASA I (indivíduos saudáveis, que não apresentam outra doença a não ser a patologia cirúrgica) e com idade de 18 a 50 anos. Os pacientes foram submetidos a cirurgia otorrinolaringológica, com duração de pelo menos 120 min. Foram excluídos os pacientes fumantes, os que receberam radiação ionizante recente e os que faziam uso regular de bebidas alcoólicas, drogas ilícitas, suplementos vitamínicos ou medicamentos (exceto para o procedimento cirúrgico). A cada paciente foi apresentado o Termo de Consentimento Livre e Esclarecido e aplicado questionário detalhado sobre os dados pessoais, informações gerais e história médica.

\section{Procedimento Anestésico}

$\mathrm{Na}$ sala de operação (SO), inseriu-se na veia cefálica de um dos braços um cateter 20G. Déficits de líquidos foram repostos com solução intravenosa (IV) de Ringer lactato 6-8 $\mathrm{ml} \mathrm{kg}{ }^{-}$ ${ }^{1} \mathrm{~h}^{-1}$. Os pacientes foram monitorados com ECG ( $\mathrm{D}_{\text {II }}$ e $\left.\mathrm{V}_{5}\right)$, pressão arterial não invasiva, frequência cardíaca e saturação periférica da oxihemoglobina $\left(\mathrm{SpO}_{2}\right)$ utilizando-se o biomonitor Dixtal (Modelo DX2010, Manaus, Brasil). Foi feita, também, monitorização do bloqueio neuromuscular (aparelho TOF Guard, Organon Tekinika, Bélgica). Para evitar hipotermia no intra-operatório, os pacientes receberam aquecimento ativo dos membros inferiores, com manta específica do aparelho de aquecimento (Warm Touch, modelo 5200, Mallinckrodt Medical, EUA). 
Os pacientes receberam medicação pré-anestésica (midazolam $3 \mathrm{mg}$ IV) na SO. Após préoxigenação por $3 \mathrm{~min}$, induziu-se a anestesia venosa total com fentanil (5 $\left.\mu \mathrm{g} \mathrm{kg}^{-1} \mathrm{IV}\right) \mathrm{e}$ propofol, este inicialmente em dosagem necessária para determinar concentração sanguínea predita de $4 \mu \mathrm{g} \mathrm{ml}^{-1}$, para determinar inconsciência, seguido de infusão contínua do fármaco em dosagem necessária para determinar concentração plasmática predita entre $\sim 3$ a $5 \mu \mathrm{g} \mathrm{ml}^{-1}$, utilizando-se a bomba de infusão Diprifusor (Fresenius Vial, França). O aparelho Diprifusor ${ }^{\circledR}$, exclusivo para uso do propofol, tem funcionamento que se baseia na farmacocinética do agente, fornecendo concentrações plasmáticas chamadas de preditas, pois são semelhantes às que seriam obtidas caso se dispusesse de análises cromatográficas do propofol no plasma. Como bloqueador neuromuscular utilizou-se o brometo de rocurônio $\left(0,6 \mathrm{mg} \mathrm{kg}^{-1} \mathrm{IV}\right)$ para facilitar a intubação orotraqueal. Utilizou-se ventilação artificial no modo controlada por volume (aparelho de anestesia Primus, Dräeger Medical, Alemanha), com volume corrente de $8 \mathrm{ml} \mathrm{kg}{ }^{-1}$ e fluxo de gases frescos constituído de oxigênio $\left(0,81 \mathrm{~min}^{-1}\right)$ e $\operatorname{ar}\left(1,21 \mathrm{~min}^{-1}\right)$ em circuito semifechado com cal sodada para absorção do dióxido de carbono $\left(\mathrm{CO}_{2}\right)$. Utilizou-se frequência respiratória de 10 a 12 movimentos por min para manter a pressão expirada de $\mathrm{CO}_{2}\left(\mathrm{P}_{\mathrm{ET}} \mathrm{CO}_{2}\right)$ de 30 a $35 \mathrm{~mm} \mathrm{Hg}$. A adequação da anestesia foi verificada pelas respostas hemodinâmicas. A concentração plasmática predita de propofol foi aumentada e doses adicionais de fentanil $\left(2 \mu \mathrm{g} \mathrm{kg}^{-1}\right)$ e rocurônio $\left(0,2 \mathrm{mg} \mathrm{kg}^{-1}\right)$ foram usadas, quando necessário.

Valores hemodinâmicos no período controle (antes da medicação pré-anestésica) e em conjunto com os valores da concentração plasmática predita de propofol foram determinados após 30, 60, 90, 120 min da indução anestésica e no final da cirurgia.

Foram registrados a duração da cirurgia, a concentração plasmática predita e o consumo total do propofol, fentanil e rocurônio. Ao final da anestesia, os pacientes receberam, ou não, 
descurarização com neostigmina $\left(30 \mu \mathrm{g} \mathrm{kg}^{-1} \mathrm{IV}\right)$, precedida por atropina $\left(10 \mu \mathrm{g} \mathrm{kg}^{-1} \mathrm{IV}\right)$, de acordo com a resposta da monitorização do bloqueio neuromuscular.

A desintubação traqueal foi realizada após a completa reversão do bloqueio neuromuscular (relação $\mathrm{T}_{4} / \mathrm{T}_{1}=1$ do nervo ulnar), com o paciente em ventilação espontânea e em condições de atender comandos verbais ou demonstrando intenção de realizar auto-extubação traqueal. No final da cirurgia, utilizou-se dipirona 1 g e tramadol $100 \mathrm{mg}$ IV para analgesia pósoperatória e ondansetrona $8 \mathrm{mg}$ IV como anti-emético. Se necessário, dipirona $1 \mathrm{~g}$ IV foi usada no primeiro dia do pós-operatório. $\mathrm{O}$ uso de outros fármacos, como antibiótico e corticosteróide, que foram administrados no pós-operatório de alguns pacientes, foi registrado. Em seguida, os pacientes foram encaminhados à Sala de Recuperação PósAnestésica. Não houve nenhum problema no intra-operatório e os pacientes tiveram boa recuperação após o ato anestésico-cirúrgico e deixaram o hospital de acordo com as normas de rotina conforme o procedimento cirúrgico.

\section{Coletas de Sangue}

As amostras de sangue venoso $(15 \mathrm{ml})$ foram coletadas em tubos contendo heparina sódica e tubos PAXgene (Qiagen/PreAnalytiX, Suíça), anteriormente à medicação pré-anestésica ( $\mathrm{M}_{1}$-controle), 120 min após a indução anestésica $\left(\mathrm{M}_{2}\right)$ e no dia posterior ao ato anestésicocirúrgico $\left(\mathrm{M}_{3}\right)$. As amostras sanguíneas coletadas com anticoagulante foram processadas imediatamente após a coleta, para avaliação dos danos oxidativos no DNA e apoptose. As amostras coletadas em tubos com estabilizador de RNA (PAXgene) permaneceram por $12 \mathrm{~h}$ em temperatura ambiente, sendo, em seguida, armazenadas em freezer $-20^{\circ} \mathrm{C}$ para posterior extração do RNA. 


\section{Isolamento de Linfócitos}

$\mathrm{O}$ isolamento de linfócitos foi feito em Ficoll ${ }^{\circledR} \cdot{ }^{20}$ Para isso, alíquotas de $2 \mathrm{ml}$ de sangue total foram homogeneizadas com $2 \mathrm{ml}$ de solução salina (PBS) e colocadas, cuidadosamente, sobre $3 \mathrm{ml}$ de Ficoll ${ }^{\circledR}$. Após centrifugação por $30 \mathrm{~min}$ a $2.500 \mathrm{rpm}$, os linfócitos (halo branco) foram retirados com auxílio de pipeta e transferidos para outro tubo contendo $4 \mathrm{ml}$ de PBS. Após nova centrifugação por $15 \mathrm{~min}$, a $1.500 \mathrm{rpm}$, os linfócitos foram utilizados para a detecção de danos no DNA e apoptose.

\section{Avaliação dos Danos no DNA pelo Teste do Cometa}

O teste do cometa, para a avaliação de danos no DNA, foi conduzido de acordo com a metodologia descrita por Singh et al. $(1988)^{21}$ e modificada por Tice et al. (1991). ${ }^{22}$ Cada alíquota de $10 \mu 1$ de linfócitos isolados foi misturada a $120 \mu 1$ de agarose de baixo ponto de fusão $(0,5 \%)$ e colocada sobre lâmina previamente coberta com uma camada de agarose de ponto de fusão normal $(1,5 \%)$. Após coberta com lamínula, a lâmina foi colocada a $4^{\circ} \mathrm{C}$, por 5 min, para solidificação da agarose. Posteriormente, a lamínula foi cuidadosamente removida e a lâmina colocada em solução de lise gelada e recém preparada $(2,5 \mathrm{M} \mathrm{NaCl}, 100$ mM EDTA, 10 mM Tris, pH 10; Triton X-100 1\% e DMSO 10\%). Para avaliação dos danos oxidativos no DNA, foi realizada a técnica que utiliza as enzimas endonuclease III (endo III) e formamidopirimidina-DNA glicosilase (FPG) para detecção, respectivamente, de pirimidinas e purinas oxidadas (Collins et al, 1993). ${ }^{23}$ Após a etapa de lise, as lâminas foram lavadas em PBS e colocadas em tampão Flare 1x (Hepes 40 mM, KCl 0,1M, albumina de soro bovino - BSA 0,2 $\mathrm{mg} / \mathrm{ml}$ e EDTA 0,5 mM, pH 8) durante $5 \mathrm{~min}$ (3 vezes). Posteriormente, foi adicionado sobre todas as lâminas, codificadas de acordo com o tratamento, $50 \mu \mathrm{l}$ do tampão de reação das enzimas (Flare 10x, $\mathrm{H}_{2} \mathrm{O}$ autoclavada e BSA; controle), ou $50 \mu$ de endo III (diluição 1:1.000), ou $50 \mu$ de FPG (diluição 1:1.000), a fim 
de detectar os diferentes tipos de bases oxidadas no DNA. Todas as lâminas foram cobertas com lamínula e incubadas por 30 min a $37^{\circ} \mathrm{C}$, em câmara úmida. Na sequência, as lâminas foram colocadas em geladeira por 15 min para solidificação da agarose, as lamínulas cuidadosamente removidas, e as lâminas transferidas para cuba de eletroforese, a qual foi preenchida com tampão alcalino gelado e recém preparado (1 mM EDTA e $300 \mathrm{mM} \mathrm{NaOH}$, pH>13). Após período de 40 min para desespiralização do DNA e expressão dos sítios álcalilábeis, a eletroforese foi conduzida a $25 \mathrm{~V}$ e $300 \mathrm{~mA}$, por $30 \mathrm{~min}$. Finalizada a eletroforese, as lâminas foram colocadas, por 15 min, em solução de neutralização $(0,4 \mathrm{M}$ de Tris, pH 7,5), fixadas com etanol absoluto, secas à temperatura ambiente e armazenadas a $4^{\circ} \mathrm{C}$. No momento da análise, as lâminas foram coradas com $50 \mu 1$ de solução de brometo de etídio (20 $\mu \mathrm{g} / \mathrm{ml}$ ), cobertas com lamínula e 100 nucleóides foram analisados, em microscópio de fluorescência acoplado ao sistema de análise de imagem (Comet Assay II - Perceptive Instruments, UK), em aumento de 400X. Como parâmetro para a mensuração dos danos no DNA considerou-se o tail intensity (\% de DNA na cauda). Todas as lâminas foram codificadas e preparadas em duplicata. Linfócitos coletados nos três momentos do estudo, foram tratados ou não com peróxido de hidrogênio $\left(100 \mu \mathrm{M} \mathrm{H}_{2} \mathrm{O}_{2}\right.$ a $4^{\circ} \mathrm{C}$, por 30 min) e utilizados, respectivamente, como controle positivo e negativo.

\section{Fenotipagem de Linfócitos e Avaliação de Apoptose por Citometria de Fluxo}

A fenotipagem de linfócitos $\mathrm{T} \mathrm{CD}^{+}$( $\mathrm{T}$ auxiliar ou helper) e $\mathrm{CD}^{+}$( $\mathrm{T}$ citotóxico) e a avaliação de apoptose foram realizadas por citometria de fluxo. Antes do início da análise, foi feita a calibração do aparelho FACSCalibur (Becton Dickinson - BD, EUA). O gate (padronizado em 10.000 eventos, isto é, 10.000 células) na população de interesse (linfócitos) foi determinado para todas as análises. 
Para controle negativo, $250 \mu \mathrm{l}$ de células recém isoladas foram misturadas a $250 \mu 1$ de solução isotônica (isoton), e a suspensão incubada, no escuro, por 15 min. Para fenotipagem das células, $250 \mu 1$ de células mononucleares foram misturadas a $100 \mu 1$ de tampão de anexina $\mathrm{V}$ marcada com isotiocianato de fluoresceína - FITC (diluído 1:10), $5 \mu \mathrm{l}$ de anexina, $5 \mu \mathrm{l}$ de 7-amino-actinomicina D (7-AAD) e $10 \mu \mathrm{l}$ de anticorpo anti-CD4. Após o período de incubação por 15 min em local escuro, foram adicionados $400 \mu$ de tampão de anexina. $\mathrm{O}$ mesmo procedimento foi realizado para a fenotipagem das células marcadas com $\mathrm{CD}^{+}$. Após a adição de cada reagente, os tubos foram agitados em vortex e as amostras foram processadas no citômetro, por período $\leq 1 \mathrm{~h}$. Os dados foram analisados pelos programas Cell Quest e FACScomp (BD, EUA). As células viáveis não se coram com anexina nem com 7-AAD, enquanto as em fase inicial de apoptose coram-se com anexina e as em fase tardia com anexina e 7-AAD.

\section{Análise da Expressão dos Genes hOGG1 e XRCC1 por PCR em Tempo Real}

Para extração do RNA de células de sangue total utilizou-se o PAXgene Blood RNA Kit de acordo com o protocolo do fabricante (Qiagen/PreAnalytiX, Suíça). A concentração de RNA total foi determinada por espectrofotômtetro (NanoDrop ND-1000) e cada amostra foi avaliada quanto à pureza pela razão de absorbância A260/280 nm. Para avaliação da qualidade das amostras, foi feito gel de agarose a 1,5\% usando o tampão TBE (tris, ácido bórico e EDTA). As amostras permaneceram em freezer $-80^{\circ} \mathrm{C}$ até a etapa de transcrição reversa, que foi feita com o High Capacity cDNA Reverse Transcription Kit, de acordo com as instruções do fabricante (Applied Biosystems - ABI, EUA) e seguindo ciclagem de $25^{\circ} \mathrm{C}$ por $10 \mathrm{~min}, 37^{\circ} \mathrm{C}$ por $120 \mathrm{~min}$ e posteriormente a $4^{\circ} \mathrm{C}$. 
As amostras foram analisadas por polymerase chain reaction (PCR) quantitativa em tempo real, em termociclador automático (ABI Prism 7500 Fast, EUA). Os valores de cada amostra foram normalizados pela razão entre os valores obtidos para o gene de interesse (hOGG1 ou $X R C C 1)$ e para o gene de referência $A C T B$ (ß-actina). Os ensaios dos primers e da sonda para os genes hOGG1 (Hs00213454_m1), XRCC1 (Hs 00959834_ml) e ACTB (4352935E) foram delineados pela ABI. Para a amplificação foi utilizado o sistema TaqMan Universal PCR Master Mix (ABI), que contém todos os reagentes necessários para a reação. $\mathrm{O}$ experimento foi realizado com volume final de reação de $10 \mu$ l. A condição de ciclagem para os genes foi de $94^{\circ} \mathrm{C}$ por 10 min para desnaturação, seguida de 40 ciclos a $95^{\circ} \mathrm{C}$ por $15 \mathrm{~s} \mathrm{e} 60^{\circ} \mathrm{C}$ por $60 \mathrm{~s}$. Para garantir a ausência de contaminação, utilizou-se, em cada reação de amplificação, um controle negativo no (ausência de cDNA) contendo os iniciadores de cada gene amplificado. Como controle da quantificação relativa $(\mathrm{QR})$ dos genes, utilizou-se pool de amostras de cDNA de indivíduos saudáveis que não foram submetidos ao procedimento cirúrgico. Dessa forma, o controle foi utilizado em toda placa de 96 poços, para todos os genes estudados.

Para a quantificação do RNA, foram utilizados os valores de Ct (Cycle Threshold) pela fórmula $2^{-\Delta \Delta \mathrm{Ct}}$. Para cada amostra, o valor de $\Delta \mathrm{Ct}$ foi determinado subtraindo a média das duplicatas dos valores de $\mathrm{Ct}$ do gene de interesse da média das duplicatas dos valores de $\mathrm{Ct}$ do gene referência $(A C T B)$. Posteriormente, para determinar o $\Delta \Delta \mathrm{Ct}$, o valor de $\Delta \mathrm{Ct}$ de cada amostra foi subtraído do valor da média de $\Delta \mathrm{Ct}$ das amostras controle (pool). Este último valor foi adicionado à fórmula $2^{-\Delta \Delta \mathrm{Ct}} \cdot{ }^{24}$ Para cada amostra foi determinada a quantidade relativa de transcrito $(\mathrm{QR})$ em cada momento do estudo.

Com base nos resultados das amostras controle (pool de indivíduos não submetidos ao ato anestésico-cirúrgico), considerou-se a faixa "normal" de QR, aquela que ficou entre 0,5 e 1,5. Dos 20 pacientes avaliados, dois foram excluídos da análise estatística para os dois genes de interesse, por terem sido considerados outliers. 


\section{Análise Estatística}

A caracterização dos pacientes está apresentada como média e desvio padrão $(\mathrm{X} \pm \mathrm{DP})$. $\mathrm{O}$ teste não paramétrico de Friedman foi utilizado para comparação das concentrações plasmáticas preditas de propofol, dos parâmetros hemodinâmicos, dos danos no DNA, da apoptose e da expressão gênica (dados apresentados como mediana, $1^{\circ}$ e $3^{\circ}$ quartis), e o teste de Tukey foi utilizado para múltiplas comparações. O teste não paramétrico de MannWhitney foi utilizado para comparar duas variáveis, como também para analisar se variáveis como idade, sexo, IMC, tipo e duração da cirurgia e doses dos fármacos utilizadas no intra- e pós-operatório dentro do momento, pudessem influenciar na expressão gênica. Valores com $\mathrm{p}<0,05$ foram considerados estatisticamente significativos.

\section{Resultados}

\section{Caracterização dos Pacientes e Atributos Hemodinâmicos}

A Tabela 1 apresenta as características da população estudada, tipo e duração da cirurgia, e doses dos fármacos utilizadas no intra-operatório. Os dados mostram que os valores da frequência cardíaca não se alteraram ao longo do ato anestésico-cirúrgico ( $p>0,05)$; que os valores das pressões sistólica e diastólica diminuíram significativamente 30 min após a indução anestésica em relação ao controle $(p<0,05)$ (Tabela 2). As concentrações plasmáticas preditas de propofol nos momentos 90 e 120 min após a indução anestésica foram maiores que 30 min após a indução (p<0,05) (Fig. 1).

\section{Efeitos do Propofol sobre o DNA}

A Figura 2 mostra os danos no DNA de linfócitos de pacientes submetidos a cirurgia e anestesia venosa com propofol nos três momentos do estudo. Em relação às quebras de fita e sítios álcali-lábeis, não houve diferença significativa entre os momentos (Fig. 2A). Resultado 
similar foi encontrado quanto aos danos oxidativos em pirimidinas $(\mathrm{p}<0,05)$ (Fig. 2C). Entretanto, foi verificada redução significativa $(p=0,009)$ de purinas oxidadas 120 min após a indução anestésica, quando comparado a $\mathrm{M}_{1}$ e $\mathrm{M}_{3}$ (Fig. 2B).

Na Tabela 3 são apresentados os danos no DNA de linfócitos coletados nos três momentos do estudo, e que foram posteriormente expostos (ou não) ao peróxido de hidrogênio. De maneira geral, o mutágeno induziu aumento significativo de danos, independentemente do momento de coleta das células $(p<0,05)$. Exceção foi detectada para os linfócitos coletados 120 min após a indução da anestesia $\left(\mathrm{M}_{2}\right)$, demonstrando menor sensibilidade das células à ação de espécies reativas sob anestesia com propofol.

\section{Avaliação ex vivo de Apoptose em Linfócitos T}

A Tabela 4 apresenta a porcentagem de linfócitos $\mathrm{T}^{\mathrm{CD}} 4^{+}$( $\mathrm{T}$ auxiliar) viáveis e em apoptose nos três momentos do estudo. Houve aumento significativo de células $\mathrm{CD}^{+}{ }^{+}$viáveis (anexina $\left.{ }^{-} / 7-\mathrm{AAD}^{-}\right)$e diminuição de apoptose precoce (anexina $\left.{ }^{+} / 7-\mathrm{AAD}^{-}\right)$nos momentos $\mathrm{M}_{2}$ e $\mathrm{M}_{3}$, em relação ao momento controle $(\mathrm{p}<0,05)$. Não se observou alteração significativa da porcentagem de apoptose na população de linfócitos citotóxicos $\left(\mathrm{CD}^{+}\right)$ao longo dos três momentos analisados, embora tenha havido pequena redução $(p=0,08)$ no dia posterior ao ato anestésico-cirúrgico (Tabela 5).

\section{Propofol e Expressão dos Genes de Reparo de DNA}

Os resultados da expressão do gene hOGGl nos três momentos do estudo estão apresentados na Figura 3. De maneira geral, a expressão de hOGGl em células do sangue periférico foi significativamente inferior no dia posterior ao ato anestésico-cirúrgico. Mais particularmente, em $\mathrm{M}_{3}$ seis pacientes (33,33\%) apresentaram expressão diminuída em comparação às amostras controle (pool de indivíduos não submetidos ao ato anestésico- 
cirúrgico), em $\mathrm{M}_{1}$ dois pacientes $(<0,5)$ e em $\mathrm{M}_{2}$, três pacientes apresentaram menores valores, enquanto um paciente apresentou maior expressão $(>1,5)$ do gene.

Com relação ao $X R C C 1$, não foi detectada diferença significativa entre os três momentos do estudo, exceto a menor expressão do gene um dia após o ato anestésico-cirúrgico $\left(\mathrm{M}_{3}\right)$, mas apenas em comparação a $\mathrm{M}_{2}(\mathrm{p}<0,05)$ (Fig. 4).

Nenhuma das variáveis analisadas (características individuais, tipo de cirurgia e fármacos utilizados no intra- e pós-operatório) teve efeito significativo sobre o padrão de expressão de hOGG1 e XRCC1 ( $\mathrm{p}>0,05)$. Contudo, quando 18 pacientes foram distribuídos em dois grupos de acordo com o tempo de duração da cirurgia (grupo $\mathrm{A}=$ até $154 \mathrm{mim}$; grupo $\mathrm{B}>154 \mathrm{~min}$ ), a expressão de XRCC1 foi maior no grupo B (Fig. 5). 
Tabela 1. Características da população estudada, tipo e duração da cirurgia, e doses dos fármacos utilizadas no intra-operatório

\begin{tabular}{ll}
\hline Variáveis & Número ou X \pm DP \\
\hline Sexo & 10 \\
$\quad$ Maculino & 10 \\
$\quad$ Feminino & $27,5 \pm 10,5$ \\
Idade (anos) & $62,8 \pm 9,6$ \\
Peso (kg) & $165,7 \pm 6,9$ \\
Altura (cm) & $22,9 \pm 3,1$ \\
IMC (kg m ${ }^{-2}$ ) & $168,0 \pm 44,0$ \\
Duração da cirurgia (min) & \\
Tipo de cirurgia & 10 \\
$\quad$ Septoplastia & 4 \\
$\quad$ Rinosseptoplastia & 1 \\
$\quad$ Sinusotomia & 5 \\
$\quad$ Timpanoplastia & \\
Dose utilizada dos fármacos & \\
no intra-operatório & $1.650,2 \pm 431,4$ \\
$\quad$ Propofol (mg) & $517,5 \pm 117,6$ \\
$\quad$ Fentanil ( $\mu$ g) & \\
$\quad$ Brometo de rocurônio $(\mathrm{mg})$ &
\end{tabular}

$\mathrm{IMC}=$ índice de massa corpórea. 


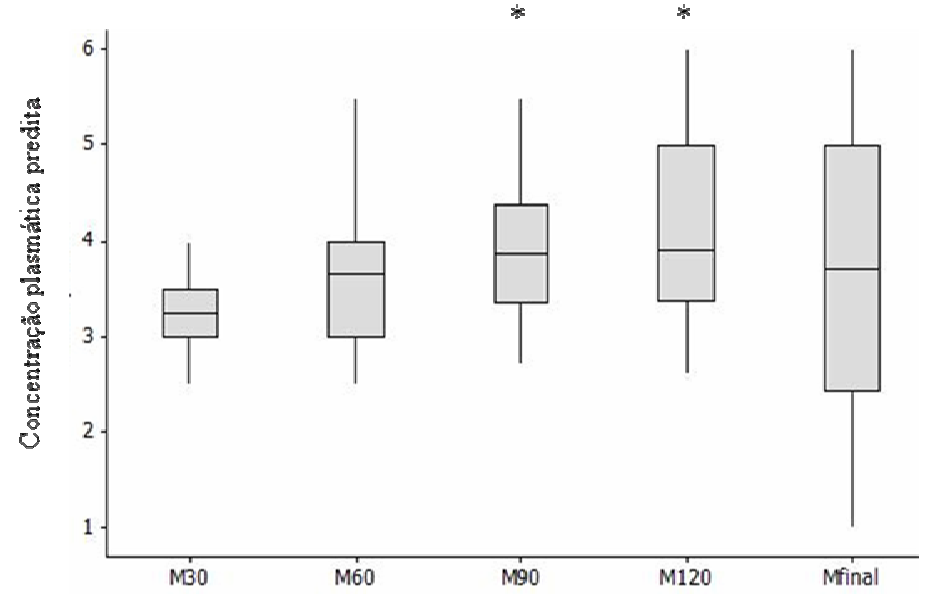

Fig. 1. Concentrações plasmáticas preditas $\left(\mu \mathrm{g} \mathrm{ml}^{-1}\right)$ de propofol nos momentos seguintes à indução anestésica. * p<0,05 em relação ao momento 30 min (M30) após a indução da anestesia.

Tabela 2. Valores dos atributos hemodinâmicos

\begin{tabular}{|c|c|c|c|c|c|c|c|}
\hline \multirow[b]{2}{*}{ Variável } & \multirow[b]{2}{*}{$\begin{array}{l}\text { Antes da } \\
\text { indução } \\
\text { (controle) }\end{array}$} & \multicolumn{2}{|c|}{$\begin{array}{c}\text { Tempo }(\min ) \\
\text { anestésica }\end{array}$} & \multicolumn{2}{|c|}{ após indução } & \multirow[b]{2}{*}{$\begin{array}{l}\text { Final da } \\
\text { cirurgia }\end{array}$} & \multirow[b]{2}{*}{$\begin{array}{c}\text { Valor } \\
\text { de p }\end{array}$} \\
\hline & & 30 & 60 & 90 & 120 & & \\
\hline \multirow[t]{2}{*}{ FC } & 77 & 77 & 76 & 81 & 76 & 78 & 0,89 \\
\hline & {$[71 ; 91]$} & {$[68 ; 84]$} & {$[64 ; 87]$} & {$[64 ; 89]$} & {$[68 ; 84]$} & {$[62 ; 84]$} & \\
\hline \multirow[t]{2}{*}{ PAS } & 116,0 & $101,0^{*}$ & 107,0 & 110,0 & 114,0 & 120,0 & $<0,01$ \\
\hline & {$[110,0 ; 129,0]$} & {$[93,0 ; 112,0]$} & {$[99,0 ; 121,0]$} & {$[108,0 ; 123,0]$} & {$[105,0 ; 126,0]$} & {$[111,0 ; 127,0]$} & \\
\hline \multirow[t]{2}{*}{ PAD } & 70,0 & $58,0^{*}$ & 64,0 & 65,0 & 69,0 & 71,0 & 0,003 \\
\hline & {$[65,0 ; 74,0]$} & {$[46,0 ; 67,0]$} & {$[57,0 ; 73,0]$} & {$[55,0 ; 70,0]$} & {$[62,0 ; 83,0]$} & {$[65,0 ; 79,0]$} & \\
\hline
\end{tabular}

Valores expressos em mediana e primeiro e terceiro quartis. FC = frequência cardíaca, PAS = pressão arterial sistólica, PAD = pressão arterial diastólica. ${ }^{*} \mathrm{p}<0,05$ em relação ao momento controle. 
A

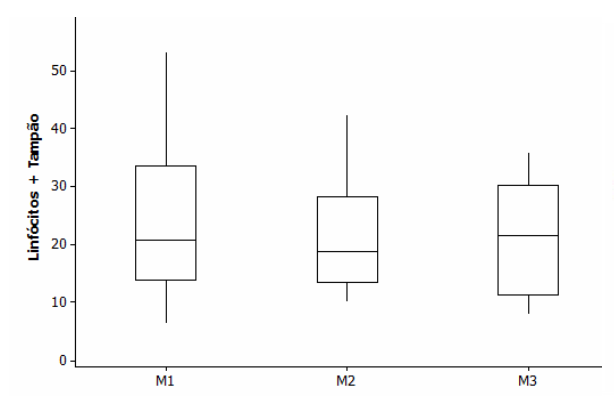

B

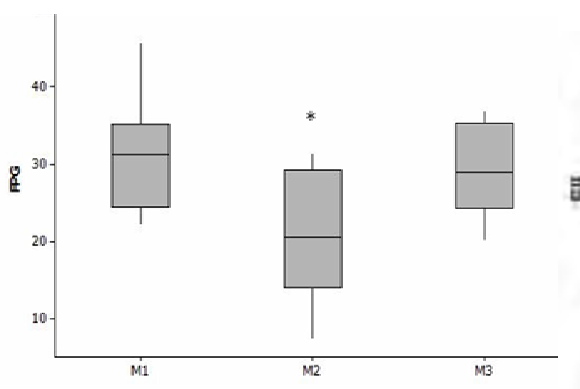

C

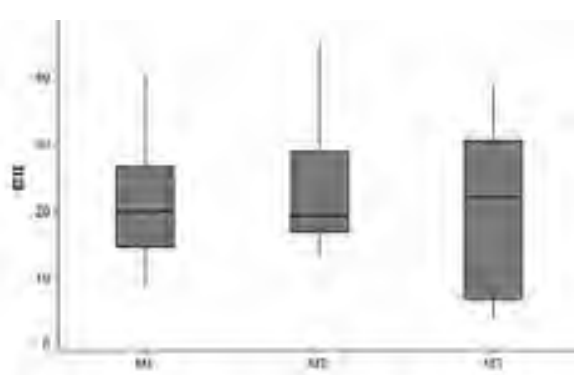

Fig. 2. Danos no DNA (tail intensity) de linfócitos de pacientes submetidos a cirurgia sob anestesia venosa com propofol nos momentos: $M_{1}$ : anteriormente à medicação pré-anestésica (controle), $M_{2}$ : aos $120 \mathrm{~min}$ da indução anestésica, $M_{3}$ : no dia posterior ao ato anestésicocirúrgico. (A) quebras; (B) purinas oxidadas; (C) pirimidinas oxidadas. " $\mathrm{p}<0,05\left(\mathbf{M}_{1}=\mathbf{M}_{3}>\mathbf{M}_{2}\right)$.

Tabela 3. Danos no DNA (tail intensity) de linfócitos obtidos dos pacientes, tratados ou não com $\mathrm{H}_{2} \mathrm{O}_{2}$ in vitro

\begin{tabular}{lccc}
\hline & \multicolumn{3}{c}{ Momentos do estudo } \\
\cline { 2 - 4 } & $\mathbf{M}_{\mathbf{1}}$ & $\mathbf{M}_{\mathbf{2}}$ & $\mathbf{M}_{\mathbf{3}}$ \\
\hline Linfócitos & $2,4[1,5 ; 3,5]$ & $3,6[2,5 ; 6,1]$ & $2,8[1,6 ; 5,9]$ \\
$\mathbf{H}_{\mathbf{2}} \mathbf{O}_{\mathbf{2}}$ & $7,3[5,5 ; 12,5]^{\#}$ & $4,1[2,3 ; 8,2]$ & $7,1[4,4 ; 10,6]^{\#}$
\end{tabular}

Valores expressos em mediana e [primeiro e terceiro quartis]. $\mathrm{M}_{1}$ : anteriormente à medicação pré-anestésica (controle), $\mathrm{M}_{2}$ : aos $120 \mathrm{~min}$ da indução anestésica e $\mathrm{M}_{3}$ : no dia posterior ao ato anestésico-cirúrgico; ${ }^{\#} \mathrm{p}<0,05$ : $\mathrm{H}_{2} \mathrm{O}_{2}\left(100 \mu \mathrm{M}, 30 \mathrm{~min}, 4^{\circ} \mathrm{C}\right) \mathrm{x}$ linfócitos. 
Tabela 4. Porcentagem de células T helper viáveis e em apoptose precoce ou tardia nos três momentos do estudo

\begin{tabular}{lcccc}
\hline Linfócitos T CD4 & \multicolumn{3}{c}{ Momentos } & Valor de p \\
\cline { 2 - 4 } & \multicolumn{1}{c}{$\mathbf{M}_{\mathbf{1}}$} & $\mathbf{M}_{\mathbf{2}}$ & $\mathbf{M}_{3}$ \\
\hline Viáveis & $91,8[87,4 ; 94,2]$ & $92,9[88,6 ; 93,9]^{*}$ & $93,1[90,2 ; 95,2]^{*}$ & 0,01 \\
Apoptose precoce & $7,0[5,3 ; 12,1]$ & $6,0[5,0 ; 10,4]^{*}$ & $5,8[4,3 ; 9,0]^{*}$ & 0,01 \\
Apoptose tardia & $0,5[0,4 ; 0,8]$ & $0,7[0,6 ; 1,1]$ & $0,7[0,4 ; 1,0]$ & 0,23 \\
\hline Valores expressos em mediana e [primeiro e terceiro quartis]. $\mathrm{M}_{1}$ : anteriormente à medicação pré-anestésica (controle), \\
$\mathrm{M}_{2}$ : aos 120 min da indução anestésica e $\mathrm{M}_{3}$ : no dia posterior ao ato anestésico-cirúrgico; ${ }^{\mathrm{p}}<0,05$ versus $\mathrm{M}_{1}$.
\end{tabular}

Tabela 5. Porcentagem de células $\mathbf{T}$ citotóxicas viáveis e em apoptose precoce ou tardia nos três momentos do estudo

\begin{tabular}{lcccc}
\hline Linfócitos T CD8 & \multicolumn{3}{c}{ Momentos } & Valor de p \\
\cline { 2 - 4 } & \multicolumn{1}{c}{$\mathbf{M}_{\mathbf{1}}$} & $\mathbf{M}_{\mathbf{2}}$ & $\mathbf{M}_{\mathbf{3}}$ \\
\hline Viáveis & $91,3[84,8 ; 94,7]$ & $91,8[86,9 ; 95,4]$ & $94,2[90,8 ; 95,4]$ & 0,08 \\
Apoptose precoce & $8,4[4,9 ; 14,6]$ & $7,7[4,5 ; 12,7]$ & $5,5[4,2 ; 9,0]$ & 0,08 \\
Apoptose tardia & $0,2[0,1 ; 0,3]$ & $0,2[0,1 ; 0,3]$ & $0,2[0,1 ; 0,2]$ & 0,95 \\
\hline Valores expressos em mediana e [primeiro e terceiro quartis]. $\mathrm{M}_{1}$ : anteriormente à medicação pré-anestésica \\
(controle), $\mathrm{M}_{2}$ : aos 120 min da indução anestésica e $\mathrm{M}_{3}$ : no dia posterior ao ato anestésico-cirúrgico.
\end{tabular}


hOGG1

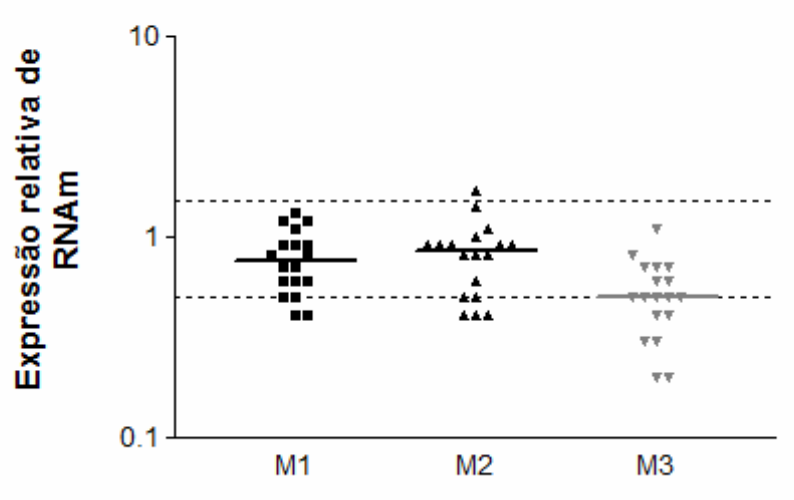

Fig. 3. Quantificação relativa $(\mathrm{QR})$ do gene $h O G G 1$ em 18 pacientes avaliados nos três momentos do estudo: $M_{1}$ : anteriormente à medicação pré-anestésica (controle), $M_{2}:$ aos 120 min da indução anestésica e $M_{3}$ : no dia posterior ao ato anestésico-cirúrgico. As barras horizontais indicam a mediana da QR em cada momento e as linhas pontilhadas indicam os limites de QR de 0,5 e 1,5. $\mathbf{p}<0,05:\left(M_{1}=M_{2}\right)>M_{3}$.

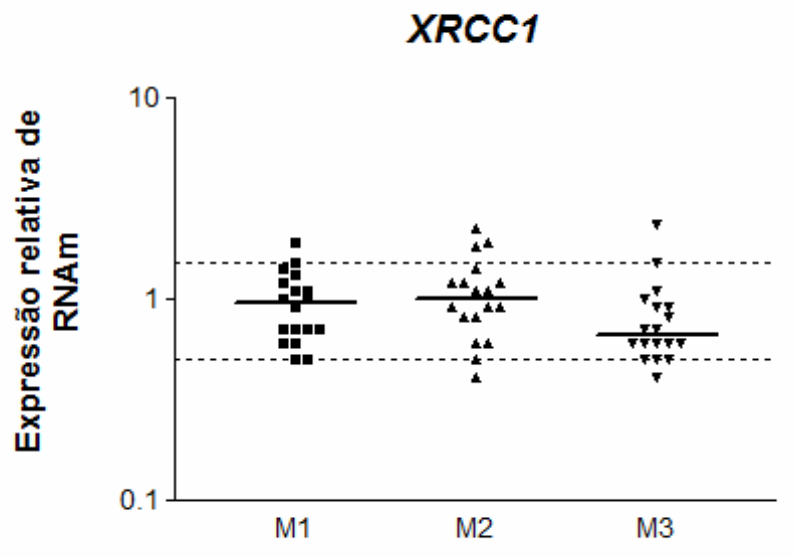

Fig. 4. Quantificação relativa $(\mathrm{QR})$ do gene $X R C C 1$ em 18 pacientes avaliados nos três momentos do estudo: $M_{1}$ : anteriormente à medicação pré-anestésica (controle), $M_{2}$ : aos 120 min da indução anestésica e $M_{3}$ : no dia posterior ao ato anestésico-cirúrgico. As barras horizontais indicam a mediana da $Q R$ em cada momento e as linhas pontilhadas indicam os limites de QR de 0,5 e 1,5. p<0,05: $M_{3}<M_{2}$. 


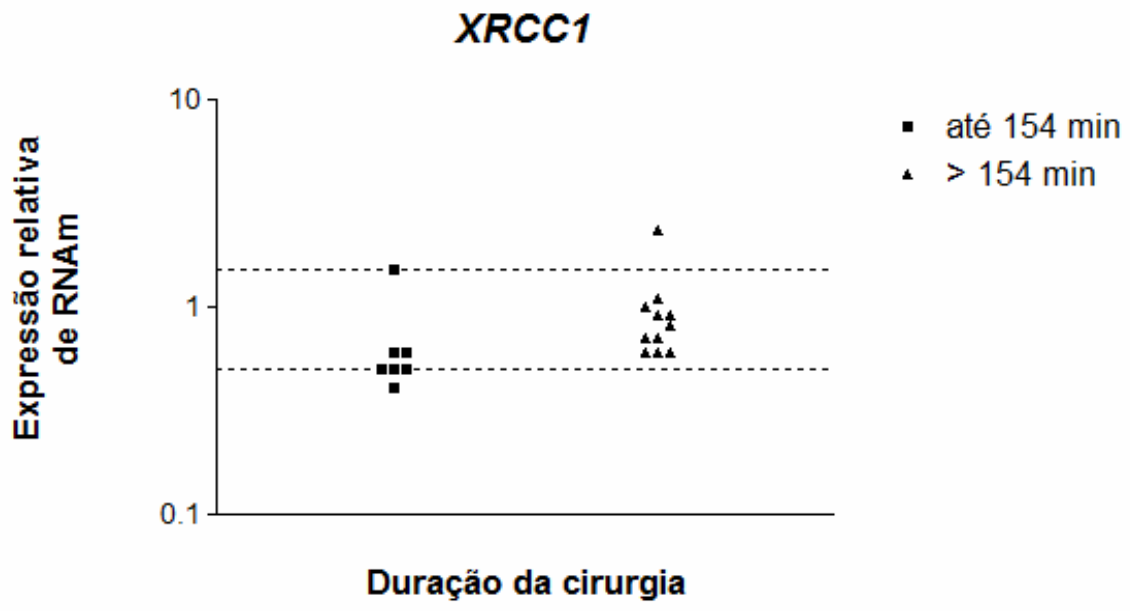

Fig. 5. Quantificação relativa $(\mathrm{QR})$ do gene $X R C C 1$ em 18 pacientes avaliados no dia seguinte ao ato anestésico-cirúrgico $\left(M_{3}\right)$, em relação à duração da cirurgia (expresso em $\log 10)(p=0,02)$.

\section{Discussão}

Desde a introdução dos anestésicos na prática clínica, há questionamentos sobre a toxicidade desses agentes. No entanto, há, ainda, poucos dados sobre o possível efeito desses compostos sobre o material genético. Assim, com a avaliação do potencial genotóxico, citotóxico e toxicogenômico de um dos anestésicos venosos mais utilizados, este estudo objetivou, também, contribuir para a prática diária da anestesiologia fornecendo informações que podem auxiliar na escolha da droga com menor efeito colateral ou deletério para o paciente.

Este estudo incluiu indivíduos adultos ASA I, de ambos os sexos, com índice de massa corpórea considerada normal. Essas características foram consideradas relevantes por conta da farmacocinética e farmacodinâmica do propofol, que podem ser alteradas por fatores como sexo, idade, peso e doença pré-existente. ${ }^{25-28}$

Com relação ao potencial genotóxico do propofol e de seus metabólitos, resultados negativos, semelhantes ao do presente estudo, foram observados em testes de mutagenicidade 
em bactérias (Salmonella typhimurium), fungos (Saccharomyces cerevisae) ${ }^{29}$ e em cultura de células $(\mathrm{CHO})$ de mamífero. ${ }^{30}$ In vivo, ausência de danos genéticos (troca entre cromátides irmãs) foi verificada em linfócitos de crianças submetidas a anestesia com propofol e cirurgia pouco invasiva. ${ }^{5}$ Da mesma forma, pacientes sob anestesia venosa com propofol e submetidos a cirurgia cardíaca não mostraram aumento no número de aberrações cromossômicas. ${ }^{7}$

O teste do cometa, na versão utilizada neste estudo, detecta além de quebras de fita simples e dupla e sítios álcali-lábeis, alterações oxidativas do DNA. ${ }^{31,23} \mathrm{O}$ menor nível de purinas oxidadas observado $2 \mathrm{~h}$ após a indução anestésica poderia ser, talvez, explicado pela propriedade antioxidante do propofol. Este poderia atuar reagindo com radicais livres induzidos pelo estresse cirúrgico, ou pelo próprio metabolismo do indivíduo, impedindo as lesões no DNA. Os resultados observados após o tratamento in vitro dos linfócitos com o peróxido de hidrogênio, em que houve menor indução de danos no DNA em células coletadas durante o ato anestésico-cirúrgico (momento de maior concentração de propofol), corroboram a maior resistência dessas ao ataque de ROS. Assim, a diminuição de purinas oxidadas aos 120 min após indução anestésica poderia estar relacionada à concentração plasmática predita do propofol utilizada durante o procedimento anestésico-cirúrgico (em torno de $4 \mu \mathrm{g} \mathrm{ml}^{-1}$ ). $\mathrm{O}$ propofol é capaz de inibir a peroxidação lipídica plasmática nas concentrações normalmente utilizadas na prática anestésica. ${ }^{10}$ Por outro lado, alguns autores acreditam que o propofol somente apresenta atividade antioxidante quando utilizado em altas concentrações, maiores que as que são normalmente utilizadas na prática clínica. ${ }^{32}$ No entanto, nossa pesquisa demonstrou que linfócitos humanos expostos a concentrações como as utilizadas na prática clínica, apresentaram menor nível de danos oxidativos no DNA. Foi anteriormente demonstrado por outros autores que o propofol (até $1 \mathrm{mM}$ ) é capaz de reduzir a citotoxicidade e prevenir os danos no DNA induzidos por peroxinitritos em cultura de astrócitos, fato que pode ser relevante à neuroproteção durante anestesia venosa. ${ }^{6}$ 
A anestesia geral e o estresse cirúrgico são considerados indutores de imunossupressão, por interferirem no sistema imunológico, ou por ativarem o eixo hipotálamo-hipófise-adrenal do sistema nervoso autônomo simpático. ${ }^{33}$ Durante situações de estresse, como cirurgia ou dor pós-operatória, os fármacos anestésicos podem estar associados à imunossupressão no período perioperatório, em virtude da ação direta sobre a imunidade celular, uma vez que podem alterar funções de células imunocompetentes e a expressão de genes responsáveis pela produção de mediadores inflamatórios. Assim, a imunossupressão pós-cirúrgica pode aumentar a possibilidade de o paciente apresentar infecções no período pós-operatório. ${ }^{33}$ Entretanto, na presente avaliação não foi detectada taxa aumentada de células $\mathrm{CD}^{+}$e $\mathrm{CD} 8^{+}$ em apoptose precoce $2 \mathrm{~h}$ após a indução da anestesia, ou mesmo no dia posterior ao ato anestésico-cirúrgico, fato que pode indicar ausência de efeito imunossupressor do propofol, com relação aos linfócitos T auxiliar e citotóxico. Contudo, deve ser ressaltado que em nosso estudo foram analisados apenas pacientes submetidos as cirurgias eletivas otorrinolaringológicas e que, a lesão tecidual induzida por procedimentos minimamente invasivos têm pequeno efeito sobre o sistema imunológico, diferentemente do que ocorre, por exemplo, com as cirurgias abdominais e ortopédicas. ${ }^{34}$

Outro aspecto que pode ser considerado é a possibilidade do propofol, devido ao seu potencial antioxidante e meia-vida de 4 a $23,5 \mathrm{~h},{ }^{35,36}$ ter prevenido a morte celular por apoptose em linfócitos $\mathrm{T}_{\mathrm{CD}}{ }^{+}$durante o ato anestésico-cirúrgico até o dia posterior à cirurgia, mesmo em baixas concentrações. Estudos anteriores demonstraram que o propofol não induz apoptose em linfócitos $\mathrm{T}$ in vitro e que, em concentrações similares às utilizadas na prática clínica, não induz apoptose em células mononucleares tratadas com lipopolissacarídeo (LPS). ${ }^{37,38}$ Pelo contrário, há estudo que demonstra que o anestésico apresenta efeito antiapoptótico, aumentando a expressão da heme oxigenase (HO)-1 e inibindo a caspase 3 , em astroglias. ${ }^{6}$ Em 2002, contudo, foi reportado que o propofol induz apoptose em cultura de 
células promielocíticas de leucemia (HL-60), via ativação de caspases 3, 6, 8 e 9, e pela via mitocondrial. ${ }^{39}$ Esses autores ressaltaram, no entanto, que diferentes tipos celulares respondem de maneiras diferentes aos mecanismos de apoptose, e que as células HL-60 são sensíveis aos estressores pró-apoptóticos.

Com relação à porcentagem de linfócitos $\mathrm{CD}^{+}$, a maior proporção de células viáveis observada nos períodos intra- e pós-operatórios está de acordo com o descrito por Pirttikangas et al. (1996), ${ }^{40}$ que detectaram, em idosos submetidos a cirurgia oftalmológica e anestesia com propofol ou isoflurano, aumento da subpopulação de T auxiliar no final da cirurgia e na manhã seguinte ao ato anestésico-cirúrgico. Relatos semelhantes mostraram aumento de linfócitos $\mathrm{T}$, principalmente de $\mathrm{CD}^{+}$e redução das células "natural killers" (NK) em pacientes sob anestesia com propofol e fentanil. ${ }^{41}$ Aumento do número absoluto de células $\mathrm{T}$ $\mathrm{CD}^{+}$devido ao aumento exclusivo de linfócitos $\mathrm{CD} 4^{+}$, mas não de $\mathrm{CD} 8^{+}$, foi observado $2 \mathrm{~h}$ após início de cirurgia sob anestesia intravenosa com propofol e sufentanil em pacientes ASA I. ${ }^{42}$ As células $\mathrm{CD} 4^{+}$têm papel crítico na resposta imune, sendo seus efeitos dependentes, principalmente, da produção e liberação de citocinas. ${ }^{43}$ Nesses mesmos pacientes submetidos a cirurgia eletiva e anestesia com propofol, detectamos aumento de citocinas próinflamatórias (IL-6 e IL-8) no dia posterior ao ato anestésico-cirúrgico (dados ainda não publicados).

Os radicais livres são moléculas importantes para o organismo, sendo gerados em processos fisiológicos normais, incluindo o metabolismo aeróbico e a resposta inflamatória. Por outro lado, sabe-se que esses mesmos radicais podem, também, induzir danos celulares. Em consequência, uma série de mecanismos, como reações antioxidantes e sistema reparo do DNA, protege as células dos ataques dessas moléculas. ${ }^{44} \mathrm{O}$ sistema de reparo do DNA, responsável pela manutenção da integridade do genoma, atua por meio de vários mecanismos, dentre os quais a excisão de bases (BER), o reparo de desaminações espontâneas e de 
oxidações e alquilações no DNA. ${ }^{45} \mathrm{O}$ gene $X R C C 1$ codifica a proteína XRCC1, que está envolvida no reparo de quebras de fita simples do DNA via BER, inclusive de danos induzidos por ROS e por agentes ionizantes e alquilantes. ${ }^{46} \mathrm{O}$ gene $h O G G 1$, por sua vez, codifica a enzima 8-oxoguanina DNA glicosilase 1 (OGG1), que atua na remoção do aducto 8-oxoguanina, também pelo mecanismo de BER. ${ }^{47}$ Nossos dados mostraram que o propofol parece não atuar diretamente sobre o padrão de expressão desses dois genes (hOGGl e $X R C C 1$ ), uma vez que os menores valores (de expressão) foram observados no dia posterior à indução anestésica, momento em que os pacientes já não estão sob efeito do anestésico.

No entanto, uma possível explicação para a menor expressão dos dois genes observada após a cirurgia, poderia ser a redução dos níveis de purinas oxidadas em linfócitos, observada após a indução da anestesia com o propofol. Com isso, as células não teriam recebido estímulo para acionar os genes responsáveis pelo reparo de danos no DNA. Contudo, ressaltamos que neste estudo a avaliação da genotoxicidade foi realizada em linfócitos, enquanto a da expressão gênica foi em células de sangue total. Outro fator que poderia ter interferido no padrão de expressão gênica é o aumento plasmático das citocinas inflamatórias IL-6 e IL-8, que foi previamente observado no dia posterior ao ato cirúrgico (dados ainda não publicados). Já foi descrito, por exemplo, que em células tumorais, citocinas inflamatórias parecem inibir o sistema de reparo do DNA. ${ }^{48}$ Por outro lado, a alteração do padrão de expressão de genes de reparo não reflete, necessariamente, a maior habilidade de reparo dos danos genéticos. Níveis diminuídos de RNAm dos genes $h O G G 1$ e XRCCl já foram descritos em linfócitos após a exposição a radiação. ${ }^{49}$

Com relação ao possível efeito dos outros fármacos utilizados para a indução anestésica no presente estudo, diferentemente dos efeitos inibitórios da morfina, os opióides sintéticos como o fentanil, parecem não alterar o sistema imune em resposta ao estresse cirúrgico. ${ }^{34}$ Além disso, já foi relatado que as drogas midazolam, fentanil, neostigmina e atropina, também 
utilizadas neste estudo, não apresentam atividade antioxidante, ação sobre o sistema imune e efeito genotóxico. ${ }^{50-52}$

Concluindo, os resultados ora apresentados mostram que a anestesia intravenosa total com propofol não induz lesões genotóxicas e citotóxicas e não parece ter ação direta sobre o padrão de expressão dos genes $h O G G 1$ e XRCC1 em células do sangue periférico de pacientes submetidos as cirurgias eletivas. Contudo, este estudo gerou questões que devem ser ainda avaliadas. Por exemplo, como seria o padrão de expressão gênica se os mesmos pacientes não estivessem sob estresse anestésico-cirúrgico? Esse tipo de anestesia teria o mesmo efeito em pacientes com estado físico mais grave e submetidos as cirurgias de grande porte e invasivas? Existe relação direta entre os níveis de transcrição dos genes de reparo e o nível de proteínas sintetizadas atuantes? Qual a relação entre os resultados encontrados e os níveis de catecolaminas e de cortisol? O período de coleta das amostras de sangue (manhã, tarde ou noite) poderia interferir nos resultados, já que o metabolismo varia durante o dia? Os efeitos da anestesia com o propofol seriam os mesmos em outro tipo celular?

Apoio Financeiro concedido pela Fundação de Amparo à Pesquisa do Estado de São Paulo (FAPESP - São Paulo, Brasil) proc. números 06/59625-6 e 06/58847-5. Os autores não têm conflitos de interesse a declarar.

\section{Referências}

1. Sardas S, Karabiyik L, Aygun N, Karakaya AE: DNA damage evaluated by the alkaline comet assay in lymphocytes of humans anaesthetized with isoflurane. Mutat Res 1998; 418:16

2. Karabiyik L, Sardas S, Polat U, KocabaS NA, Karakaya AE: Comparison of genotoxicity of sevoflurane and isoflurane in human lymphocytes studied in vivo using the comet assay. Mutat Res 2001; 492:99-107 
3. Alleva R, Tomasetti M, Solenghi MD, Stagni F, Gamberini F, Bassi A, Fornasari PM, Fanelli G, Borghi B: Lymphocyte DNA damage precedes DNA repair or cell death after orthopaedic surgery under general anaesthesia. Mutagenesis 2003; 18:423-8

4. Szyfter K, Szulc R, Mikstacki A, Stachecki I, Rydzanicz M, Jaloszynski P: Genotoxicity of inhalation anaesthetics: DNA lesions generated by sevoflurane in vitro and in vivo. J Appl Genet 2004; 45:369-74

5. Krause TK, Jansen L, Scholz J, Bottcher H, Wappler F, Burmeister MA, am Esch JS: Propofol anesthesia in children does not induce sister chromatid exchanges in lymphocytes. Mutat Res 2003; 542:59-64

6. Acquaviva R, Campisi A, Murabito P, Raciti G, Avola R, Mangiameli S, Musumeci I, Barcellona ML, Vanella A, Li Volti G: Propofol attenuates peroxynitrite- mediated DNA damage and apoptosis in cultured astrocytes: an alternative protective mechanism. Anesthesiology 2004; 101:1363-71

7. Karahalil B, Yagar S, Bahadir G, Durak P, Sardas S: Diazepam and propofol used as anesthetics during open-heart surgery do not cause chromosomal aberrations in peripheral blood lymphocytes. Mutat Res 2005; 581:181-6

8. Braz MG, Magalhães MR, Salvadori DM, Ferreira AL, Braz LG, Sakai E, Braz JR: Evaluation of DNA damage and lipoperoxidation of propofol in patients undergoing elective surgery. Eur J Anaesthesiol 2009; 26:654-60

9. Shafer A, Doze VA, Shafer SL, White PF: Pharmacokinetics and pharmacodynamics of propofol infusions during general anesthesia. Anesthesiology 1988; 69:348-56

10. Aarts L, Van der Hee R, Dekker I, de Jong J, Langemeijer H, Bast A: The widely used anesthetic agent propofol can replace $\alpha$-tocopherol as an antioxidant. FEBS Letters 1995; $357: 83-5$

11. Stratford N, Murphy P: Antioxidant activity of propofol in blood from anaesthetized patients. Eur J Anaesthesiol 1998; 15:158-60

12. De La Cruz JP, Zanca A, Carmona JA, de la Cuesta FS: The effect of propofol on oxidative stress in platelets from surgical patients. Anesth Analg 1999; 89:1050-5

13. Hall G, Ali W: The stress response and its modification by regional anaesthesia. Anaesthesia 1998; 53:10-2

14. Kehrer JP: The Haber-Weiss reaction and mechanisms of toxicity. Toxicology 2000; 149:43-50

15. Vasconcelos SML, Goulart MOF, Moura JBF, Manfredini V, Benfato MS, Kubota LT: Reactive oxygen and nitrogen species, antioxidants and markers of oxidative damage in human blood: main analytical methods for their determination. Quim Nova 2007; 30:1323-38

16. Salo M, Pirttikangas CO, Pulkki K: The effect of propofol emulsion and thiopentone on T helper cell type-1/type-2 balance in vitro. Anaesthesia 1997; 52:341-4

17. Espanol T, Todd GB, Soothill JF: The effect of anaesthesia on the lymphocyte response to phytohaemagglutinin. Clin Exp Immunol 1974; 18:73-9

18. Slade MS, Simmons RL, Yunis E, Greenberg LJ: Immunodepression after major surgery in normal patients. Surgery 1975; 78:363-72

19. Inada T, Yamanouchi Y, Jomura S, Sakamoto S, Takahashi M, Kambara T, Shingu K: Effect of propofol and isoflurane anaesthesia on the immune response to surgery. Anaesthesia 2004; 49:954-9

20. Braz MG, Favero Salvadori DM: Influence of endogenous and synthetic female sex hormones on human blood cells in vitro studied with comet assay. Toxicol In Vitro 2007; 21:972-6

21. Singh NP, Mccoy MT, Tice RR, Schneider EL: A simple technique for quantitation of low levels of DNA damage in individual cells. Exp Cell Res 1988; 175:184-91 
22. Tice RR, Andrews PW, Hirai O, Singh NP: The single cell gel (SCG) assay: an electrophoretic technique for the detection of DNA damage in individual cells. Adv Exp Med Biol 1991; 283:157-64

23. Collins AR, Duthie SJ, Dobson VL. Direct enzymic detection of endogenous oxidative base damage in human lymphocyte DNA. Carcinogenesis 1993; 14,1733-5

24. Livak KJ, Schmittgen TD: Analysis of relative gene expression data using real-time quantitative PCR and the $2^{-\Delta \Delta \mathrm{Ct}}$ method. Methods $2001 ; 25: 402-8$

25. Kay NH, Sear JW, Uppington J, Cockshott ID, Douglas EJ: Disposition of propofol in patients undergoing surgery. A comparison in men and women. $\mathrm{Br} \mathrm{J}$ Anaesthesiol 1986; 58:1075-9

26. Schnider TW, Minto CF, Shafer SL, Gambus PL, Andresen C, Goodale DB, Youngs EJ: The influence of age on propofol pharmacodynamics. Anesthesiology 1999; 90:1502-16

27. Kirkpatrick T, Cockshott ID, Douglas EJ, Nimmo WS: Pharmacokinetics of propofol (diprivan) in elderly patients. Br J Anaesthesiol 1988; 60:146-50

28. Morcos WE, Payne JP: The induction of anaesthesia with propofol ("Diprivan") compared in normal and renal failure patients. Postgrad Med J 1985; 61 Suppl:62-3

29. Trapani G, Altomare C, Liso G, Sanna E, Biggio G: Propofol in anesthesia. Mechanism of action, structure-activity relationships, and drug delivery. Curr Med Chem 2000; 7:249-71

30. Tomioka S, Nakajo N: No genotoxic effect of propofol in chinese hamster ovary cells: analysis by sister chromatid exchanges. Acta Anaesthesiol Scand 2000; 44:1261-5

31. Tice RR, Agurell E, Anderson D, Burlinson B, Hartmann A, Kobayashi H, Miyamae Y, Rojas E, Ryu JC, Sasaki YF: Single cell gel/comet assay: guidelines for in vitro and in vivo genetic toxicology testing. Environ Mol Mutagen 2000; 35:206-21

32. Green TR, Bennett SR, Nelson VM: Specificity and properties of propofol as an antioxidant free radical scavenger. Toxicol Appl Pharmacol 1994; 129:163-9

33. Kurosawa S, Kato M: Anesthetics, immune cells, and immune responses. J Anesth 2008; 22:263-77

34. Levy JH, Tanaka KA: Inflammatory response to cardiopulmonary bypass. Ann Thorac Surg 2003; 75:S715-20

35. Schüttler J, Stoeckel H, Schwilden H: Pharmacokinetic and pharmacodynamic modelling of propofol ("Diprivan") in volunteers and surgical patients. Postgrad Med J 1985; 61 Suppl 3:53-4

36. Gepts E, Camu F, Cockshott ID, Douglas EJ: Disposition of propofol administered as constant rate intravenous infusions in humans. Anesth Analg 1987; 66:1256-63

37. Delogu G, Marandola M, Tellan G, Moretti S, Marcellini S, Iacoella C, Rizzitano D, Signore L: Proapoptotic effect of propofol on T cells. Minerva Anestesiol 2001; 67:705-11

38. Song HK, Jeong DC: The effect of propofol on cytotoxicity and apoptosis of lipopolysaccharide-treated mononuclear cells and lymphocytes. Anesth Analg 2004; 98: 1724-8

39. Tsuchiya M, Asada A, Arita K, Utsumi T, Yoshida T, Sato EF, Utsumi K, Inoue M: Induction and mechanism of apoptotic cell death by propofol in HL-60 cells. Acta Anaesthesiol Scand 2002; 46:1068-74

40. Pirttikangas CO, Salo M, Peltola O: Propofol infusion anaesthesia and the immune response in elderly patients undergoing ophthalmic surgery. Anaesthesia 1996; 51:318-23

41. Brand JM, Frohn C, Luhm J, Kirchner H, Schumucker P: Early alterations in the number of circulating lymphocyte subpopulations and enhanced proinflammatory immune response during opioid-based general anesthesia. Shock 2003; 20:213-7 
42. Schneemilch CE, Ittenson A, Ansorge S, Hachenberg T, Bank U: Effect of 2 anesthetic techniques on the postoperative proinflammatory and anti-inflammatory cytokine response and cellular immune function to minor surgery. J Clin Anesth 2005; 17:517-27

43. Powrie F, Coffman RL: Cytokine regulation of T-cell function: potential for therapeutic intervention. Immunol Today 1993; 14:270-4

44. Hussain SP, Hofseth LJ, Harris CC: Radical causes of cancer. Nature 2003; 3:276-85

45. Heijmakers JHJ: Genome maintenance mechanisms for preventing cancer. Nature $2001 ; 411: 366-74$

46. Lei YC, Hwang SJ, Chang CC, Kuo HW, Luo JC, Chang MJ, Cheng TJ: Effects on sister chromatid exchange frequency of polymorphisms in DNA repair gene XRCC1 in smokers. Mutat Res 2002; 519:93-101

47. Janssen K, Schlink K, Gotte W, Hippler B, Kaina B, Oesch F: DNA repair activity of 8-oxoguanine DNA glycosylase 1 (OGG1) in human lymphocytes is not dependent on genetic polymorphism Ser326/Cys326. Mutat Res 2001; 486:207-16

48. Jaiswal M, LaRusso NF, Burgart LJ, Gores GJ: Inflammatory Cytokines Induce DNA damage and inhibit DNA repair in cholangiocarcinoma cells by a nitric oxide-dependent mechanism1. Cancer Res 2000; 60:184-90

49. Sudprasert W, Navasumrit P, Ruchirawat M: Effects of low-dose gamma radiation on DNA damage, chromosomal aberration and expression of repair genes in human blood cells. Int J Hyg Environ Health 2006; 209:503-11

50. Kang MY, Tsuchiya M, Packer L, Manatabe M: In vitro study on antioxidant potential of various drugs used in the perioperative period. Acta Anaesthesiol Scand 1998; 42:4-12

51. Tsuchiya M, Asada A, Maeda K, Ueda Y, Sato EF, Shindo M, Inoue AM: Propofol versus midazolam regarding their antioxidant activities. Am J Respir Crit Care Med 2001; 163:26-31

52. Chinev S, Bakalova R, Kovacheva S, Ribarov SR: Lipid peroxidation in rat lung induced by neuroleptanalgesia and its components. Eur J Anaesthesiol 1998; 15:686-94 


\section{Evaluation of DNA damage and lipoperoxidation of propofol in patients undergoing elective surgery

\author{
Ana Lúcia Ferreira ${ }^{\mathrm{c}}$, Leandro Gobbo Braz ${ }^{\mathrm{b}}$, Eduardo Sakai ${ }^{\mathrm{b}}$ \\ and José Reinaldo Braz
} \\ Mariana Gobbo Braz ${ }^{a}$, Marcelo Rocha Magalhães ${ }^{b}$, Daisy Maria Salvadori ${ }^{a}$,}

\begin{abstract}
Background and objectives Inhaled anaesthetics have been studied regarding their genotoxic and mutagenic potential in vivo. Propofol differs from volatile anaesthetics because it does not show mutagenic effects and it has been reported to be an antioxidant. However, there are no studies with propofol and genotoxicity in vivo. The study aimed to evaluate the hypothesis that propofol is not genotoxic and it inhibits lipid peroxidation [malondialdehyde (MDA)] in patients undergoing propofol anaesthesia.
\end{abstract}

Methods ASA physical status I patients scheduled for elective surgery, lasting at least $90 \mathrm{~min}$, were enrolled in this study. Initially, the estimated plasma concentration of propofol was targeted at $4 \mu \mathrm{g} \mathrm{ml}^{-1}$ and then maintained at 2-4 $\mathrm{g} \mathrm{ml}^{-1}$ until the end of surgery. Haemodynamic data were determined at baseline (before premedication) and in conjunction with target-controlled infusion of propofol: after tracheal intubation, 30,60 and $90 \mathrm{~min}$ after anaesthesia induction and at the end of the surgery. Venous blood samples were collected at baseline, after tracheal intubation, at the end of the surgery and on the postoperative first day for evaluating DNA

\section{Introduction}

Deoxyribonucleic acid (DNA) is continuously exposed to exogenous and endogenous compounds that can modify its function. Within exogenous agents, inhaled anaesthetics such as halothane, isoflurane and sevoflurane have been studied regarding their genotoxic and mutagenic potential in vivo [1-4]. Propofol (2,6 diisopropylphenol), a rapid-onset, short-acting intravenous anaesthetic, is widely used for the induction and maintenance of anaesthesia as well for long-term sedation in the intensive care unit $[5,6]$.

Genotoxic assays are commonly used in humans to monitor DNA damage. The single-cell gel electrophoresis assay (comet assay) has been widely used in both invitro and in-vivo studies, because it is a simple and sensitive methodology for measuring single-strand and double-strand breaks, alkali labile sites, oxidative lesions and DNA repair [7]. The comet assay belongs to the group of indicator tests, as opposed to mutagenicity tests, because it detects DNA damage that may result in mutations. Due to the assay's methodological advantages and its increasing acceptance within the scientific com- damage in white blood cells (WBCs), by comet assay, and MDA levels.

Results Haemodynamic data did not differ among times. No statistically significant differences were observed for the levels of DNA damage in WBCs, nor in plasma MDA, among the four times.

Conclusion Propofol does not induce DNA damage in WBCs and does not alter MDA in plasma of patients. Eur $J$ Anaesthesiol 26:654-660 (c) 2009 European Society of Anaesthesiology.

\section{European Journal of Anaesthesiology 2009, 26:654-660}

Keywords: alkaline comet assay, free radical scavengers, general anaesthesia, malondialdehyde, propofol

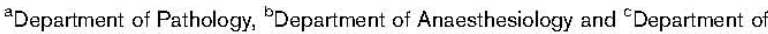
Internal Medicine, Botucatu Medical School, São Paulo State University-UNESP, Botucatu, São Paulo, Brazil

Correspondence to Mariana Gobbo Braz, Faculdade de Medicina de Botucatu, UNESP, Departamento de Patologia, Distrito de Rubião Junior, s/n. CEP 18618000, Botucatu, São Paulo, Brazil

Tel: +55 143882 8255; fax: +55 143815 2348; e-mail: mgbraz@hotmail.com

munity, the comet assay is gaining in importance and already has a significant role in genotoxicity testing strategies [8].

Propofol differs from volatile anaesthetics such as isoflurane and sevoflurane because it does not show mutagenic effects in vitro and in vivo $[6,9,10]$. Some studies had already showed the genotoxicity of the inhaled anaesthetics, evaluated by the comet assay [2-4]. However, there are no studies with propofol and comet assay in vivo.

Propofol was the first of a new class of intravenous anaesthetic agents, the alkylphenols [11], and it contains a phenolic structure similar to $\alpha$-tocopherol and butylated hydroxytoluene, known as free radical scavengers [12,13]. It is well known that reactive species interact with macromolecules, modifying their structure or function and may conduct to abnormalities that affect cell or tissue functions leading to cell transformation or death [14].

Propofol has been reported to be an antioxidant [15] and it can attenuate lipid peroxidation [16,17]. As surgery not 
only intensifies the oxidative stress by generating reactive oxygen species (ROS) but also weakens the biological defence system against ROS attack, the antioxidant activity of drugs used during the perioperative period, which possibly normalizes the impaired redox state in the patient, is of fundamental importance and great clinical interest [18]. By inhibiting lipoperoxidation and blocking formation of malondialdehyde (MDA), propofol can protect blood and other tissues from ROS and other situations as reperfusion injury after ischaemia [12,17]. Therefore, the study aimed to evaluate the hypothesis that propofol is not genotoxic and inhibits lipid peroxidation (MDA) in patients undergoing propofol anaesthesia.

\section{Methods}

This study was approved by the Medical Ethics Committee from the Botucatu Medical School, UNESP. Twelve adult ASA physical status I patients, aged 19-50 years and scheduled for elective minor surgery (ophthalmology, othorinolaringology or plastic surgery) lasting at least $90 \mathrm{~min}$, were enrolled in this study. All of them answered a detailed questionnaire about their lifestyle, health status and previous exposure to environmental pollutants and signed the informed consent. Patients with some disease, smokers, alcoholics and those who were under medication or received radiation were excluded. None of the patients' histories indicated prior use of antioxidant supplement. So, we have limited the confounding factors to avoid possible additional DNA damage. Then, in our study, all the patients were healthy and they were their own controls (before anaesthesia and surgery - baseline).

\section{Anaesthetic procedures}

In the operating room, a 20 -gauge peripheral intravenous line was inserted in the cephalic vein of the arm. Fluids deficits were replaced with lactated Ringer's solution at $6-8 \mathrm{ml} \mathrm{kg}^{-1} \mathrm{~h}^{-1}$. Standard clinical monitoring was performed: electrocardiogram (DII lead), peripheral oxygen saturation $\left(\mathrm{SpO}_{2}\right)$, noninvasive arterial pressure (systolic and diastolic) and monitoring of neuromuscular blockade by train-of-four count at the adductor pollicis (TOFGuard, Organon Teknika/Biometer, Denmark). To avoid intraoperative hypothermia, the patients received active skin-surface warming with a specific blanket from a warming device (Warm Touch, model 5200; Mallinckrodt Medical, Hazelwood, Missouri, USA). All patients were premedicated in the operating room with midazolam $3 \mathrm{mg}$ intravenously (Dormonid, Roche, São Paulo, Brazil). After preoxygenation for $3 \mathrm{~min}$, anaesthesia was induced with fentanyl $5 \mu \mathrm{g} \mathrm{kg}^{-1}$ intravenously (Fentanil, Janssen, São Paulo, Brazil) and a target-controlled infusion of propofol (Diprivan PFC, Astra Zeneca, Milan, Italy) was administered $2 \mathrm{~min}$ later by a computer-controlled infusion pump (Diprifusor, Fresenius Vial, Brezins, France). Initially, the estimated plasma concentration of propofol was targeted at $4 \mu \mathrm{g} \mathrm{ml}^{-1}$ in order to reach loss of consciousness. Rocuronium bromide $0.6 \mathrm{mg} \mathrm{kg}^{-1}$ intravenous (Esmeron, Organon, Holland) was given to facilitate orotracheal intubation. Estimated plasma concentration of propofol was maintained at $2-4 \mu \mathrm{g} \mathrm{ml}^{-1}$ until the end of surgery. The lungs were mechanically ventilated using volume-controlled mode (Primus anaesthesia machine, Drager Medical, Germany) with a tidal volume of $8 \mathrm{ml} \mathrm{kg}^{-1}$ of $40 \%$ oxygen $\left(0.81 \mathrm{~min}^{-1}\right)$ in air $\left(1.21 \mathrm{~min}^{-1}\right)$ and a respiratory rate of $10-12$ breaths $/ \mathrm{min}$ to maintain an end-tidal $\mathrm{CO}_{2}\left(\mathrm{P}_{\mathrm{ET}} \mathrm{CO}_{2}\right)$ concentration of $30-35 \mathrm{mmHg}$. Nitrous oxide was never used in order to avoid possible additional DNA damage. Adequacy of anaesthesia during maintenance was assessed based on haemodynamic responses. Estimated plasma concentration of propofol was increased and additional doses of fentanyl $2 \mu \mathrm{g} \mathrm{kg}^{-1}$ and rocuronium $0.2 \mathrm{mg} \mathrm{kg}^{-1}$ were used when necessary if the patients were judged to be inadequately anaesthetized.

Haemodynamic data at baseline (before premedication) and in conjunction with target-controlled infusion of propofol were measured after tracheal intubation and after 30,60 and $90 \mathrm{~min}$ of anaesthesia induction and at the end of the surgery. Neuromuscular block was reversed with neostigmine $3 \mu \mathrm{g} \mathrm{kg}^{-1}$ (Normastig, União Química, São Paulo, Brazil) and atropine $10 \mu \mathrm{g} \mathrm{kg}^{-1}$ intravenously (Atropion, Ariston, São Paulo, Brazil) at the end of surgery. Tracheal extubation was performed after full reversal of neuromuscular blockade (ulnar nerve $\mathrm{T}_{4} / \mathrm{T}_{1}$ ratio $=1$ ), spontaneous ventilation and the ability to follow verbal comments or else demonstrate purposeful unilateral movement (attempting self-extubation). Ondansetron $8 \mathrm{mg}$ intravenously (Nausedron, Cristália, São Paulo, Brazil) was utilized for antiemesis. Intravenous dipyrone $1 \mathrm{~g}$ (Novalgina, Hoechst, Rio de Janeiro, Brazil) and tramadol $100 \mathrm{mg}$ (Tramal, Pfizer, São Paulo, Brazil) were used for postoperative analgesia at the end of the surgery. If necessary, dipyrone $1 \mathrm{~g}$ intravenously was used the first day postoperatively. The duration of anaesthesia and intraoperative propofol $(\mathrm{mg})$, fentanyl $(\mu \mathrm{g})$ and rocuronium $(\mathrm{mg})$ dosages were recorded.

\section{Assessment of genotoxicity and oxidative stress}

Venous blood samples were collected in EDTA tubes $(5 \mathrm{ml})$ at four times: before patients were premedicated $\left(\mathrm{M}_{1}\right.$, baseline), after tracheal intubation $\left(\mathrm{M}_{2}\right)$, at the end of the surgery $\left(\mathrm{M}_{3}\right)$ and at the postoperative first day $\left(\mathrm{M}_{4}\right)$. All samples were coded. A volume of $10 \mu$ l of whole blood was used for the comet assay and the remaining blood was centrifuged at $1500 \mathrm{rpm}$ for $10 \mathrm{~min}$ and plasma was stored at $-70^{\circ} \mathrm{C}$ until MDA analysis.

The comet assay followed the protocols described by Singh et al. [19] and Tice et al. [20], with some modifications. Every step was carried out under indirect light. A volume of $5 \mu \mathrm{l}$ of fresh collected blood was added to $100 \mu \mathrm{l}$ of $0.5 \%$ low melting point agarose at $37^{\circ} \mathrm{C}$, layered 
into a precoated slide with $1.5 \%$ normal agarose, covered with a cover slip and left for $5 \mathrm{~min}$ at $4^{\circ} \mathrm{C}$ to solidify the agarose. Afterwards, the cover slip was carefully removed and slides immersed into a cold lysis solution $\left(2.5 \mathrm{moll}^{-1}\right.$ $\mathrm{NaCl}, 100 \mathrm{mmol}^{-1}$ EDTA, $10 \mathrm{mmol}^{-1}$ Tris, $\mathrm{pH} 10 ; 1 \%$ Triton X-100 and $10 \%$ dimethyl sulfoxide) for $3 \mathrm{~h}$. Slides were then washed in phosphate buffered saline (PBS) for $5 \mathrm{~min}$ and immersed into a freshly prepared alkaline buffer $\left(1 \mathrm{mmoll}^{-1}\right.$ EDTA, $300 \mathrm{mmoll}^{-1} \mathrm{NaOH}, \mathrm{pH}$ $>13$ ) in a horizontal electrophoresis tank. After $20 \mathrm{~min}$ DNA unwinding period, electrophoresis was conducted at $25 \mathrm{~V}\left(0.8 \mathrm{~V} \mathrm{~cm}^{-1}\right)$ and $300 \mathrm{~mA}$ for $20 \mathrm{~min}$. Following $15 \mathrm{~min}$ neutralization $\left(0.4 \mathrm{moll}^{-1}\right.$ Tris, $\left.\mathrm{pH} 7.5\right)$, slides were fixed with absolute ethanol and stored at $4^{\circ} \mathrm{C}$. Prior to analysis, the slides were stained with $50 \mu \mathrm{l}$ of ethidium bromide $\left(20 \mu \mathrm{g} \mathrm{ml}^{-1}\right)$ and scored in a fluorescent microscope at $400 \times$ magnification. Images from 100 nucleoids (50 from two replicate slides from each sample) were analysed per time per patient, using the Comet Assay II image system (Perceptive Instruments, Haverhill, Suffolk, UK). Lymphocytes treated with $200 \mu \mathrm{moll}^{-1}$ of hydrogen peroxide $\left(\mathrm{H}_{2} \mathrm{O}_{2}\right)$ for $5 \mathrm{~min}$, at $4^{\circ} \mathrm{C}$, were used as positive control, every time an electrophoresis was performed (data not shown).

Tail intensity (percentage of tail DNA) and tail moment (tail DNA $\times$ total DNA by the tail centre of gravity), both in arbitrary units, were calculated to estimate DNA damage. Coded slides were used and a blind analysis was done.

Lipid peroxidation in the plasma was determined according to the protocol adapted by Templar et al. [21], where MDA produced during lipid peroxidation of lipids served as an index of oxidative stress. MDA reacts with 2-thiobarbituric acid (TBA) to generate a pink product, which is measured at $553 \mathrm{~nm}$ by fluorescence detector. MDA in plasma was measured using an automated Waters High Performance Liquid Chromatography (HPLC; Alliance model 2695; Milford, Massachusetts, USA). One hundred microlitres of plasma were mixed with $500 \mu \mathrm{l}$ of trichloroacetic acid (TCA, 10\% w/v) and $10 \mu \mathrm{l}$ of butylated hydroxytoluene (BHT, $5 \%$ in EtOH) to stop further lipid peroxidation, vortexed and placed in a waterbath at $95^{\circ} \mathrm{C}$ for $20 \mathrm{~min}$. At the end of incubation, the samples were cooled at room temperature for $5 \mathrm{~min}$ and centrifuged for $10 \mathrm{~min}$ at $14000 \mathrm{rpm}$. Three hundred microlitres of supernatant were combined with $50 \mu \mathrm{l}$ of $\mathrm{KOH}\left(3.065 \mathrm{moll}^{-1}\right)$ and $650 \mu \mathrm{l}$ of TBA $(0.4 \% \mathrm{w} / \mathrm{v}$ in acetate buffer, $\mathrm{pH} 3.5$ ), vortexed, incubated at $95^{\circ} \mathrm{C}$ for $45 \mathrm{~min}$, cooled at room temperature for $5 \mathrm{~min}$, filtered $(0.45 \mu \mathrm{m})$ and injected onto HPLG system. The mobile phase was isocratic with phosphate buffer and aceto-

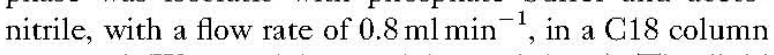
was used (Waters, $4.6 \mathrm{~mm} \times 75 \mathrm{~mm}, 3.5 \mu \mathrm{m}$ ). The lipid peroxidation was monitored from a calibration curve for 1,1,3,3-tetraethoxypropane (TEP). The content of cellular membrane TBA reactive substances (TBARSs) was expressed in nanomol of MDA per millilitre.

\section{Statistical analysis}

The sample size of the group was estimated by literature data [2,3]. The software 'Statistica 6.0' was used for statistical analysis. DNA damage data (tail intensity and tail moment), expressed as median and first and third quartiles, were analysed using the Friedman test, whereas haemodynamic, target-controlled infusion of propofol and MDA data were expressed as mean $(X) \pm \mathrm{SD}$. Analysis of variance was used for repeated measures. The power of the test used was $80 \%$ and the significance was set at $P<0.05$.

\section{Results}

Table 1 shows the general characteristics of the studied population. Our study included healthy adult persons with ASA I, of both sexes, with BMI considered normal. These aspects are important because pharmacokinetics of propofol can be altered with age and weight. All patients were submitted to elective noninvasive surgery.

Haemodynamic data (heart rate, systolic and diastolic pressures) did not differ significantly $(P>0.05)$ among the times (Table 2). Target-controlled infusion of propofol decreased significantly $(P<0.05)$ after tracheal intubation, during the first hour ( 30 and $60 \mathrm{~min})$ of anaesthesia and at the end of the surgery in relation to anaesthesia induction.

Table 3 presents DNA damage (tail intensity and tail moment, respectively) in white blood cells (WBCs) from patients submitted to propofol anaesthesia, detected by the alkaline comet assay. No statistically significant differences among the four times were observed, in both parameters $(P>0.05)$, showing lack of genotoxicity of propofol in vivo. Figure 1 shows undamaged and damaged DNA from nucleoids of WBCs from a patient submitted to propofol anaesthesia.

\begin{tabular}{llc} 
Table 1 General characteristics of the studied population \\
\hline Sex & Male & 5 \\
& Female & 7 \\
Age (year) & & $28.8 \pm 9.8$ \\
Weight (kg) & & $62.3 \pm 10.3$ \\
Height (cm) & & $165.9 \pm 6.2$ \\
BMl (kg m ${ }^{2}$ ) & Mammoplasty & $22.6 \pm 3.1$ \\
Type of surgery & Corneal transplantation & 2 \\
& Tonsilloadenoidectomy & 1 \\
& Septopasty & 1 \\
& Tympanoplasty & 5 \\
Duration of anaesthesia (min) & Propofol (mg) & $152.0 \pm 47.0$ \\
Intraoperative anaesthesia & Fentanyl ( $\mu$ g) & $433.0 \pm 317.0$ \\
& Rocuronium (mg) & $66.0 \pm 16.0$ \\
&
\end{tabular}

Data are mean $\pm S D$ or numbers of patients. 
Table 2 Haemodynamic data

\begin{tabular}{|c|c|c|c|c|c|c|c|}
\hline & \multirow[b]{2}{*}{ Baseline } & \multirow[b]{2}{*}{ After tracheal intubation } & \multicolumn{3}{|c|}{ Time after anaesthesia induction (min) } & \multirow[b]{2}{*}{ End of surgery } & \multirow[b]{2}{*}{$P$} \\
\hline & & & 30 & 60 & 90 & & \\
\hline HR (beats $\min ^{-1}$ ) & $75 \pm 11$ & $74 \pm 18$ & $74 \pm 9$ & $74 \pm 17$ & $72 \pm 20$ & $72 \pm 16$ & 0.99 \\
\hline SAP $(\mathrm{mmHg})$ & $122 \pm 16$ & $108 \pm 14$ & $107 \pm 16$ & $117 \pm 17$ & $116 \pm 16$ & $116 \pm 23$ & 0.13 \\
\hline $\mathrm{DAP}(\mathrm{mmHg})$ & $70 \pm 12$ & $62 \pm 14$ & $65 \pm 11$ & $65 \pm 18$ & $65 \pm 11$ & $70 \pm 17$ & 0.29 \\
\hline
\end{tabular}

Data are mean $\pm S D$. DAP, diastolic arterial pressure; HR, heart rate; SAP, systolic arterial pressure.

Representative chromatogram of plasma MDA from a patient during propofol anaesthesia is shown in Fig. 2. No statistically significant differences $(P>0.05)$ were observed for the MDA $\left(\mathrm{nmol} \mathrm{ml}^{-1}\right)$ measures in plasma from patients among all times studied (Fig. 3). Thus, propofol did not decrease lipoperoxidation.

\section{Discussion}

The most important findings of this study are that the propofol is not genotoxic in WBCs and it does not decrease plasma lipid peroxidation in ASA I patients undergoing elective surgery.

The comet assay is capable of detecting DNA damage with great sensitivity and it has been used for identifying genotoxins in environmental and occupational biomonitoring studies, functioning as a complementary tool for clinical research $[22,23]$. It is particularly useful as a tool for the evaluation of local genotoxicity, especially for organs/cell types which cannot easily be evaluated with other standard tests. A positive result in an appropriately performed in-vivo comet assay indicates genotoxicity of the test compound in the tissue tested and gains particular significance when a mutagenic potential of the test compound has already been demonstrated in vitro. Such findings will have practical consequences in the riskassessment processes and further development of substances. A negative result indicates the absence of genotoxic activity of the test compound detectable by the comet assay in the organ(s) tested [8], as observed in our study with propofol anaesthesia. Human biomonitoring studies using this assay provide an efficient tool for measuring human exposure to genotoxicants, thus helping in risk assessment and hazard identification. DNA lesions leading to effects in the comet assay can not only be strand breaks, which may be relevant for the formation of chromosome aberrations, but also DNA modifications

\begin{tabular}{|c|c|c|}
\hline & Tail intensity & Tail moment \\
\hline Baseline & $0.88[0.47,1.15]$ & $0.22[0.09,1.34]$ \\
\hline After tracheal intubation & $1.19[0.76,1.59]$ & $0.22[0.09,1.01]$ \\
\hline End of the surgery & $0.91[0.61,1.20]$ & $0.29[0.10,0.76]$ \\
\hline Postoperative first day & $0.94[0.72,1.26]$ & $0.13[0.07,0.18]$ \\
\hline
\end{tabular}

Data are median [first, third] quartiles. There are no significant differences among times $(P>0.05)$ such as abasic sites with relevance for the induction of gene mutations. However, it has to be recognized that the primary lesions detected by the comet assay may also be correctly repaired without resulting in permanent genetic alterations. Other drawbacks such as technical variability and interpretation are some of its disadvantages [24].

This assay has been used to demonstrate that propofol attenuates peroxynitrite-mediated DNA damage and apoptosis in cultured astrocytes [11]. It has been reported that propofol and its metabolites did not induce sister chromatid exchanges (SCEs) in Chinese hamster ovary cells [9]. In addition, this anaesthetic did not induce SCEs in children lymphocytes [10] and did not increase chromosomal aberrations in cardiac surgery patients [6]. Such data give support to our findings that showed the absence of propofol genotoxicity by using the alkaline version of the comet assay. Our study is the first one to demonstrate that propofol is not genotoxic in vivo. It is important to conduct in-vitro experiments to understand a substance's mode of action, but it is essential to evaluate genotoxicity in the whole organism. If a drug was shown to induce genotoxic effects in vitro, a negative in-vivo comet assay, generally in combination with other negative tests, provides further evidence that genotoxic effects detected in vitro have no relevance for the in-vivo situation [8].

\section{Fig. 1}

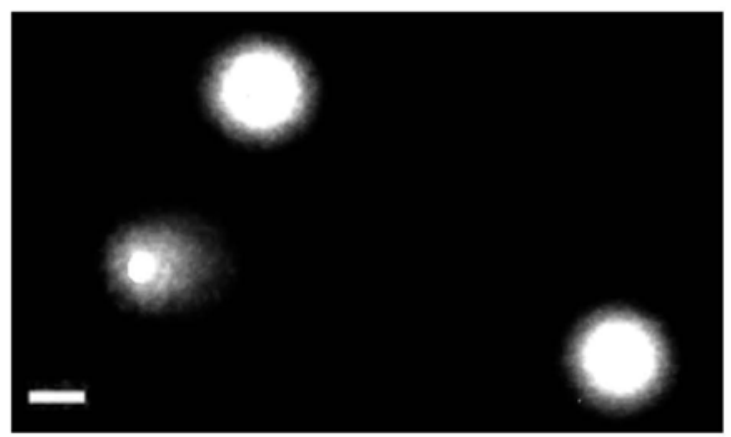

Representative comet images from nucleoids of human white blood cells during propofol anaesthesia without damage ('round') and with DNA damage ('comet'). DNA was stained with ethidium bromide. $B a r=5 \mu \mathrm{m}$. 
Fig. 2

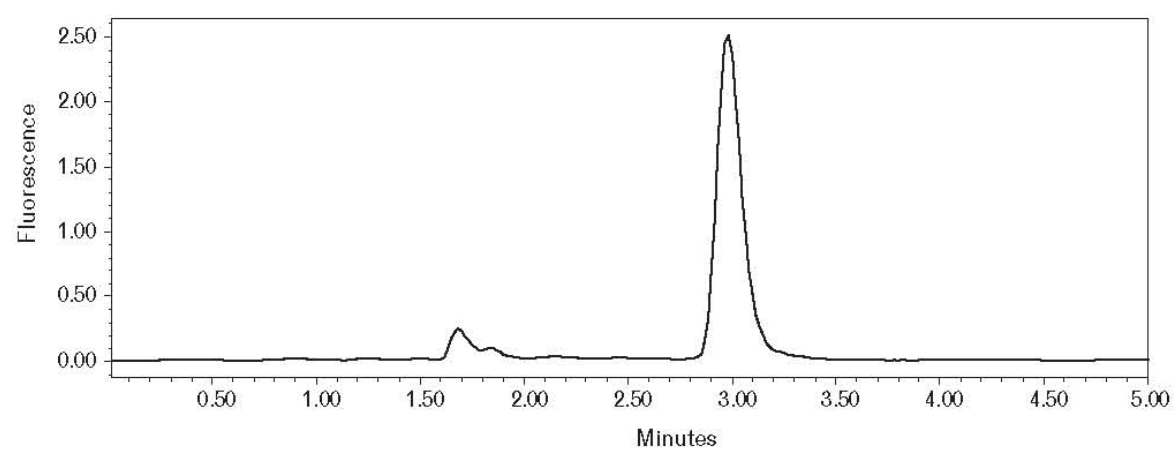

Chromatogram of plasma malondialdehyde (peak) from a patient during propofol anaesthesia.

The time point 'after tracheal intubation' was selected to evaluate whether DNA damage was associated with anaesthesia and not with surgery and also to evaluate a possible effect of the stress induced by tracheal intubation. According to Alleva et al. [4], it is difficult to assess in vivo whether anaesthetics or surgical stress is the main cause of the cell damage. These authors evaluated genotoxicity in patients submitted to sevoflurane anaesthesia and did not find significant alterations in DNA after 15 min anaesthesia induction before surgery. These data are in agreement with those seen in our study. The genotoxicity study at the postoperative first day was chosen for two reasons. First, the duration of $90 \mathrm{~min}$ of surgery could not be sufficient to reveal a genotoxic effect of propofol, so blood samples were collected in the first day of the surgery. Second, if DNA damage was increased at the end of the surgery, it would be important to evaluate the capacity of the repair system in removing

Fig. 3

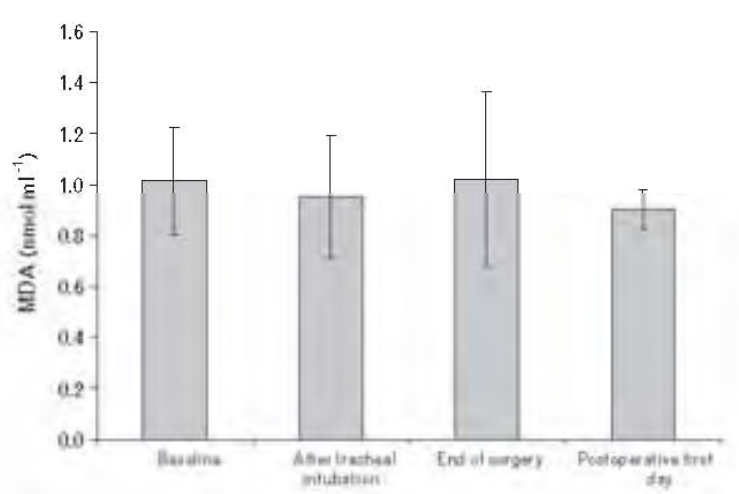

Plasma malond aldahyde levels (nmol ml- $)$ at times of the study. Data are $X \pm \mathrm{SO}$. There are no significant differences among tmes $(P=0.54)$. the lesions until $24 \mathrm{~h}$ after surgery. However, no significant DNA damage was found among the times studied.

Few studies have demonstrated that genetic material can be damaged with the halogenated anaesthetics [2-4]. These authors included patients classified as physical status I and II (a patient with mild systemic disease, systemic disturbance due to surgical condition), aged patients [2,3] submitted to major orthopaedic [4] or abdominal surgeries [2,3]. It is known that DNA can be damaged by many factors such as age and diseases, as diabetes type 1 and 2, atherosclerosis, Alzheimer's disease [25-28], among others. Our study has enrolled no elderly patients and all of them were classified as ASA I (a normal healthy patient, no disease other than surgical abnormality, no systemic disturbances), undergoing minor surgeries. So, we tried to limit the confounding factors to avoid possible additional DNA damage, because the comet assay is essentially a comparative test. Under this condition, the patients were their own controls.

Blood is a very convenient source of cells for genotoxic monitoring in human. The advantages of WBCs are clear: they are easily obtained, are in large numbers and do not require tissue disaggregation. These also include the relative speed and simplicity in performing the assay. On the contrary, there are disadvantages of using WBCs, such as interference and heterogeneity of different cell types. Although WBCs are, like all tissues, highly specialized, they can be seen as reflecting the overall state of the organism, insofar as they circulate through the whole body. However, often it is important to consider the level of damage in a particular organ (with its specific metabolism), in which case WBCs may not be a good guide [29]. Consequently, WBCs or lymphocytes cannot be regarded as typical somatic cells but because they circulate in the body, their cellular, nuclear and metabolic state, including DNA, reflects overall body exposure. 
There are different approaches to score comets and all of them have advantages and disadvantages. According to Tice et al. [7], analysing comets depends on the resources of the investigator and the experimental design. When the image analysis parameters are utilized, derived metric such as tail moment has to be provided also with tail length or with percentage of migrated DNA. Nowadays, there is a tendency to use more percentage DNA in tail, as recommended by Collins et al. [30]. In our study, tail moment and tail intensity have shown similar results, demonstrating lack of genotoxicity of propofol. Then, both parameters gave us support to present our findings.

As it is difficult to measure ROS directly in vivo, it is necessary to rely on the quantification of their reaction products such as protein carbonyls, DNA and lipoperoxidation [31]. Once lipid peroxidation is a chain reaction in cell membranes, the lipid hydroperoxide formed is unstable and can decompose to various species including MDA [14]. Therefore, MDA is one of several lowmolecular-weight end products formed by decomposition of secondary lipid peroxidation products [32,33], and it is a potential biomarker of oxidative stress in plasma [34].

Propofol contains a phenolic hydroxyl group, which has been reported to be an antioxidant [15,35]. Propofol is normally delivered in $10 \%$ intralipid emulsion, which could increase radical-scavenging activity of this anaesthetic [12]. However, it has been shown that intralipid emulsion interacts with ROS to a lesser degree than propofol itself [36]. Some authors [37] have demonstrated that plasma concentrations of propofol able to inhibit lipid peroxidation are in the range of $3-5 \mu \mathrm{g} \mathrm{ml}^{-1}$ [15], which is clinically used in anaesthesia. On the contrary, other authors [12] believe that only higher concentrations of propofol could show scavenging activity. Thus, it seems unlikely that it is capable of acting as an efficient scavenger of free radicals at the therapeutic levels normally used in achieving anaesthesia. Thus, as our study was conducted with plasma levels of propofol around $3 \mu \mathrm{g} \mathrm{ml}^{-1}$, this factor may have contributed in not decreasing MDA levels.

Using TBARS assay, Manataki et al. [16] reported that anaesthesia with continuous propofol infusion $\left(10 \mathrm{mg} \mathrm{kg}^{-1} \mathrm{~h}^{-1}\right)$, in 10 patients undergoing laparoscopic surgery, showed a significant scavenging action on the free radical production $\left(2.2 \mathrm{nmol} \mathrm{ml}^{-1}\right)$. In addition, infusion of propofol $\left(3-6 \mathrm{mg} \mathrm{kg}^{-1} \mathrm{~h}^{-1}\right)$ caused a significant reduction in the atrial tissue lipoperoxidation (TBARS) when compared with the fentanyl $\left(10-30 \mu \mathrm{g} \mathrm{kg}^{-1} \mathrm{~h}^{-1}\right)$, during coronary artery bypass grafting surgery [17]. Differently, the present study demonstrated no decrease in lipoperoxidation during propofol anaesthesia. Probably, those previous findings could be due to ischaemiareperfusion human models that could stimulate the scavenging action of propofol. In the present study, our patients were in good health and they were submitted to elective nonischaemia-nonreperfusion surgery. As recommended, we quantified MDA by HPLC using a fluorescence detector due to its high analytical sensitivity and specificity, especially to study plasma lipid peroxidation in humans [38].

The antioxidant properties of propofol, being an effective inhibitor of lipid peroxidation, could be of clinical importance, maybe when it is used in high concentration, showing scavenging activity effects and/or when it is utilized in anaesthesia for cardiac or vascular surgery, for transplantation surgery or during sedation of the critically ill, artificially ventilated patients in the intensive care unit with sepsis, severe burns [37].

It has been previously described that surgical procedures can cause DNA damage [4], which can be associated with a great burst of oxidative activity of neutrophils during the anti-inflammatory response, leading to further production of ROS [39]. In our study, the use of fentanyl can contribute to a decrease in the surgical stress factor, as this potent opioid is described as minimizer of intraoperative haemodynamic changes. Regarding the drugs utilized in the current study, it is believed that midazolam has lower antioxidant potential as compared with propofol [40], whereas fentanyl [41], neostigmine and atropine [18] have no antioxidant activity.

Since anaesthetics were introduced in clinical practice, there was concern about the toxicity of these agents. With evolution of genetics, it becomes real to study the toxicity in the level of genetic material. All drugs including the anaesthetics have benefits and hazard effects. The key is to choose the best anaesthetic with minimum toxic effect for patients. Thus, our study may contribute to our daily practices and ways of thinking what is the best choice for our patients. However, further genotoxic and oxidative stress studies during propofol anaesthesia are necessary, especially in patients with poor physical status who are submitted to invasive major surgeries.

In conclusion, propofol does not induce DNA damage in WBCs and does not alter MDA in plasma of patients.

\section{Acknowledgements}

This work was supported by CAPES. The authors thank Assistant Professor Lídia Raquel de Carvalho (Department of Bioestatistics, Institute of Biosciences, UNESP, Botucatu, São Paulo State, Brazil) for statistical advice; Camila Renata Corrêa-Camacho (Department of Internal Medicine of Botucatu Medical School, UNESP) and Assistant Professor Kyung-Jin Yeum (Jean Mayer USDA Human Nutrition Research Center on Aging, Tufts University, Washington St, Boston, Massachusetts, USA) for MDA analysis advice. M.R. Magalhães and M.G. Braz were granted a scholarship from FAPESP. 


\section{References}

1 Husum B, Wulf HC, Niebuhr E, et al. Sister chromatid exchanges in lymphocytes of humans anaesthetized with isoflurane. $\mathrm{Br} J$ Anaesth 1984; 56:559-564.

2 Sardas S, Karabiyik L, Aygun N, Karakaya AE. DNA damage evaluated by the alkaline comet assay in lymphocytes of humans anaesthetized with isoflurane. Mutat Res $1998 ; \mathbf{4 1 8 : 1 - 6 .}$

3 Karabiyik L, Sardas S, Polat U, et al. Comparison of genotoxicity of sevoflurane and isoflurane in human lymphocytes studied in vivo using the comet assay. Mutat Res 2001; 492:99-107.

4 Alleva R, Tomasetti M, Solenghi MD, et al. Lymphocyte DNA damage precedes DNA repair or cell death after orthopaedic surgery under general anaesthesia. Mutagenesis 2003; 18:423-428.

5 Shafer A, Doze VA, Shafer SL, White PF. Pharmacokinetics and pharmacodynamics of propofol infusions during general anesthesia. Anesthesiology 1988; 69:348-356.

6 Karahalil B, Yagar S, Bahadir G, et at. Diazepam and propofol used as anesthetics during open-heart surgery do not cause chromosomal aberrations in peripheral blood lymphocytes. Mutat Res 2005; 581:181186.

7 Tice RR, Agurell E, Anderson D, et al. Single cell gel/comet assay: guidelines for in vitro and in vivo genetic toxicology testing. Environ Mol Mutagen 2000; 35:206-221.

8 Brendler-Schwaab S, Hartmann A, Pfuhler S, Speit G. The in vivo comet assay: use and status in genotoxicity testing. Mutagenesis 2005; 20:245254

9 Tomioka S, Nakajo N. No genotoxic effect of propofol in Chinese hamster ovary cells: analysis by sister chromatid exchanges. Acta Anaesthesiol Scand 2000; 44:1261-1265.

10 Krause TK, Jansen L, Scholz J, et al. Propofol anesthesia in children does not induce sister chromatid exchanges in lymphocytes. Mutat Res 2003 . 542:59-64.

11 Acquaviva R, Campisi A, Murabito $P$, et al. Propofol attenuates peroxynitritemediated DNA damage and apoptosis in cultured astrocytes: an alternative protective mechanism. Anesthesiology 2004; 101:1363-1371.

12 Green TR, Bennett SR, Nelson VM. Specificity and properties of propofol as an antioxidant free radical scavenger. Toxicol Appl Pharmacol 1994; 129:163-169.

13 De La Cruz JP, Zanca A, Carmona JA, de la Cuesta FS. The effect of propofol on oxidative stress in platelets from surgical patients. Anesth Analg 1999; 89:1050-1055.

14 Kehrer JP. The Haber-Weiss reaction and mechanisms of toxicity. Toxicology 2000; 149:43-50.

15 Murphy PG, Myers DS, Davies MJ, et al. The antioxidant potential of propofol (2,6-diisopropyl-phenol). Br J Anaesthesiol 1992; 68:613-618.

16 Manataki AD, Tselepis AD, Glantzounis GK, et af. Lipid peroxidation and the use of emulsified propofol in laparoscopic surgery. Surg Endosc 2001; 15:950-953.

17 Sayin MM, Ozatamer O, Tasoz R, et al. Propofol attenuates myocardial lipid peroxidation during coronary artery bypass grafting surgery. $\mathrm{Br} J$ Anaesth 2002; 89:242-246.

18 Kang MY, Tsuchiya M, Packer L, Manabe M. In vitro study on antioxidant potential of various drugs used in the perioperative period. Acta Anaesthesiol Scand 1998; 42:4-12.

19 Singh NP, McCoy MT, Tice RR, Schneider EL. A simple technique for quantitation of low levels of DNA damage in individual cells. Exp Cell Res 1988; 175:184-191.

20 Tice RR, Andrews PW, Hirai O, Singh NP. The single cell gel (SCG) assay: an electrophoretic technique for the detection of DNA damage in individual cells. Adv Exp Med Biol 1991; 283:157-164

21 Templar J, Kon SP, Milligan TP, et af. Increased plasma malondialdehyde levels in glomerular disease as determined by a fully validated HPLC method. Nephrol Dial Transplant 1999; 14:946-951.

22 Gontijo AM, Marcondes JP, Elias FN, et at. DNA damage in cytologically normal urothelial cells of patients with a history of urothelial cell carcinoma. Environ Mol Mutagen 2002; 40:190-199.

23 Braz MG, Favero Salvadori DM. Influence of endogenous and synthetic female sex hormones on human blood cells in vitro studied with comet assay. Toxicol in Vitro 2007; 21:972-976.

24 Dhawan A, Bajpayee M, Parmar D. Comet assay: a reliable tool for the assessment of DNA damage in different models. Cell Bio Toxicol 2009; 25:5-32.

25 Dinçer $\mathrm{Y}, \mathrm{Akçay} \mathrm{T}$, llkova $\mathrm{H}$, et at. DNA damage and antioxidant defense in peripheral leukocytes of patients with type I diabetes mellitus. Mutat Res $2003 ; 19: 49-55$.

26 Pitozzi V, Giovanelli L, Bardini G, et at. Oxidative DNA damage in peripheral blood cells in type 2 diabetes mellitus: higher vulnerability of polymorphonuclear leukocytes. Mutat Res 2003; 28:129-133.

27 Botto N, Masetti S, Petrozzi L, et al. Elevated levels of oxidative DNA damage in patients with coronary artery disease. Coron Artery Dis 2002; 13:269-274.

28 Kadioglu E, Sardas S, Aslan S, et al. Detection of oxidative DNA damage in lymphocytes of patients with Alzheimer's disease. Biomarkers 2004; 9:203-209.

29 Collins AR. The comet assay for DNA damage and repair: principles, applications and limitations. Mol Biotechnol 2004; 26:249-261.

30 Collins AR, Oscoz AA, Brunborg G, et at. The comet assay: topical issues. Mutagenesis 2008; 23:143-151.

31 Drury JA, Nycyk JA, Cooke RW. Comparison of urinary and plasma malondialdehyde in preterm infants. Clin Chim Acta 1997; 263:177-185.

32 Esterbauer $\mathrm{H}$. Estimation of peroxidative damage: a critical review. Pathol Biol (Paris) 1996; 44:25-28.

33 Vasconcelos SML, Goulart MOF, Moura JBF, et at. Reactive oxygen and nitrogen species, antioxidants and markers of oxidative damage in human blood: main analytical methods for their determination. Quim Nova 2007; 30:1323-1338

34 Kadiiska MB, Gladen BC, Baird DD, et at. Biomarkers of oxidative stress study II: are oxidation products of lipids, proteins, and DNA markers of $\mathrm{CCl} 4$ poisoning? Free Radic Biol Med 2005; 38:698-710.

35 Eriksson $O$, Pollesello $P$, Saris NE. Inhibition of lipid peroxidation in isolated rat liver mitochondria by the general anaesthetic propofol. Biochem Pharmacol 1992; 44:391-393.

36 Demiryurek AT, Cinel I, Kahraman S, et al. Propofol and intralipid interact with reactive oxygen species: a chemiluminescence study. $\mathrm{Br} J$ Anaesth $1998 ; \mathbf{8 0}: 649-654$

37 Aarts L, van der Hee R, Dekker l, et af. The widely used anesthetic agent propofol can replace alpha-tocopherol as an antioxidant. FEBS Lett 1995; 357:83-85

38 Knight JA, Pieper RK, McClellan L. Specificity of the thiobarbituric acid reaction: its use in studies of lipid peroxidation. Clin Chem 1988; $34: 2433-2438$.

39 Simms HH, D'Amico R. Posttraumatic auto-oxidative polymorphonuclear neutrophil receptor injury predicts the development of nosocomial infection. Arch Surg 1997; 132:171-177.

40 Tsuchiya M, Asada A, Maeda K, et at. Propofol versus midazolam regarding their antioxidant activities. Am J Respir Crit Care Med 2001; 163:26-31.

41 Chinev S, Bakalova R, Kovacheva S, Ribarov SR. Lipid peroxidation in rat lung induced by neuroleptanalgesia and its components. Eur $J$ Anaesthesiol 1998; 15:686-694. 


\section{CONCLUSÕES}

Frente à avaliação do potencial genotóxico, citotóxico e toxicogenômico dos anestésicos isoflurano e propofol em pacientes com estado físico ASA I submetidos a cirurgia eletiva não-invasiva sob anestesia geral, os dados mostram que:

1) a anestesia inalatória com o isoflurano não induz danos oxidativos no DNA;

2) a anestesia venosa com o propofol está associada a menor nível de purinas oxidadas no DNA de linfócitos;

3) a anestesia com o isoflurano não altera a porcentagem de células T $\mathrm{CD} 4^{+}$e $\mathrm{CD} 8^{+}$;

4) a anestesia com o propofol reduz a porcentagem de apoptose em linfócitos $T$ auxiliar $\left(\mathrm{CD} 4^{+}\right)$

5) os genes de reparo hOGG1 e XRCCl apresentam menor expressão em células de sangue periférico no dia posterior ao ato anestésico-cirúrgico com o isoflurano ou com o propofol;

6) a expressão do gene anti-apoptótico $B C L-2$ apresenta menor expressão no dia posterior à cirurgia sob anestesia inalatória com o isoflurano.

Diante dos resultados encontrados, pode-se concluir que a anestesia inalatória com o isoflurano e a anestesia venosa com o propofol, em pacientes com estado físico ASA I e submetidos a cirurgia eletiva, não apresentam atividades genotóxica e citotóxica, e também não parecem ter ação direta sobre o padrão de expressão gênica. 


\section{REFERÊNCIAS*}

Aardema MJ, MacGregor JT. Toxicology and genetic toxicology in the new era of “toxicogenomics”: impact of "-omics” technologies. Mutat Res. 2002;499:13-25.

Aarts L, Van der Hee R, Dekker I, de Jong J, Langemeijer H, Bast A. The widely used anesthetic agent propofol can replace $\alpha$-tocopherol as an antioxidant. FEBS Lett. $1995 ; 357: 83-5$.

Acquaviva R, Campisi A, Murabito P, Raciti G, Avola R, Mangiameli S, et al. Propofol attenuates peroxynitrite- mediated DNA damage and apoptosis in cultured astrocytes: an alternative protective mechanism. Anesthesiology. 2004;101:1363-71.

Alleva R, Tomasetti M, Solenghi MD, Stagni F, Gamberini F, Bassi A, et al. Lymphocyte DNA damage precedes DNA repair or cell death after orthopaedic surgery under general anaesthesia. Mutagenesis. 2003;18:423-8.

Baden JM, Kelley M, Wharton RS, Hitt BA, Simmon VF, Mazze RI. Mutagenicity of halogenated ether anesthetics. Anesthesiology. 1977;46:346-50.

Barcisnki MA. Morte celular. In: Ferreira CG, Rocha JC, editors. Oncologia molecular. São Paulo: Atheneu; 2004a. p. 57.

Barcisnki MA. Morte celular. In: Ferreira CG, Rocha JC, editors. Oncologia molecular. São Paulo: Atheneu; 2004b. p. 60-1.

Benhamou S, Sarasin A. Variability in nucleotide excision repair and câncer risk: a review. Mutat Res. 2000;462:149-58.

*International Committee of Medical Journal Editors. Uniform Requirements for Manuscripts Submitted to Biomedical Journal: sample references[homepage on the Internet]. Bethesda: U.S. National Library of Medicine; 2003[last updated 2009 May 14].

Available from:http://www.nlm.nih.gov/bsd/uniform_requirements.html 
Braz MG, Magalhães MR, Salvadori DM, Ferreira AL, Braz LG, Sakai E, et al. Evaluation of DNA damage and lipoperoxidation of propofol in patients undergoing elective surgery. Eur J Anaesthesiol. 2009;26:654-60.

Bustin SA. Absolute quantification of mRNA using real time reverse transcription polymerase chain reaction assays. J Mol Endocrinol. 2000;25:169-93.

Cheng CR. Inflammatory response to anesthesia and ways to attenuate it. Adv Anesth. $2005 ; 23: 107-41$.

Collins AR, Duthie, SJ, Dobson VL. Direct enzymic detection of endogenous oxidative base damage in human lymphocyte DNA. Carcinogenesis. 1993;14:1733-5.

Corbett TH. Cancer and congenital anomalies associated with anesthetics. Ann NY Acad Sci. $1976 ; 271: 58-66$.

Delogu G, Moretti S, Antonucci A, Marcellini S, Masciangelo R, Famularo G, et al. Apoptosis and surgical trauma: dysregulated expression of death and survival factors on peripheral lymphocytes. Arch Surg. 2000;135:1141-7.

Delogu G, Marandola M, Tellan G, Moretti S, Marcellini S, Iacoella C, et al. Proapoptotic effect of propofol on T cells. Minerva Anestesiol. 2001a;67:705-11.

Delogu G, Moretti S, Famularo G, Antonucci A, Signore L, Marcellini S, et al. Circulating neutrophils enhibit enhanced apoptosis associated with mitocondrial dysfunctions after surgery under general anesthesia. Acta Anaesthesiol Scand. 2001b;45:87-94.

Delogu G, Moretti S, Famularo G, Marcellini S, Santini G, Antonucci A, et al. Mitochondrial perturbations and oxidant stress in lymphocytes from patients undergoing surgery and general anesthesia. Arch Surg. 2001c;136:1190-6. 
Delogu G, Famularo G, Moretti S, De Luca A, Tellan G, Antonucci A. Interleukin-10 and apoptotic death of circulating lymphocytes in surgical/anesthesia trauma. J Trauma. 2001d;51:92-7.

Eger EI $2^{\text {nd }}$, White AE, Brown CL, Biava CG, Corbett TH, Stevens WC. A test of the carcinogenicity of enflurane, isoflurane, halothane, methoxyflurane and nitrous oxide in mice. Anesth Analg. 1978;57:678-94.

Eger EI $2^{\text {nd }}$. New inhaled anesthetics. Anesthesiology. 1994;80:906-22.

El Azab SR, Rosseel PMJ, De Lange JJ, van Wijk EM, van Strik R, Scheffer GJ. Effect of VIMA with sevoflurane versus TIVA with propofol or midazolam-sufentanil on the cytokine response during CABG surgery. Eur J Anaesthesiol. 2002;19:279-82.

Espanol T, Todd GB, Soothill JF. The effect of anaesthesia on the lymphocyte response to phytohaemagglutinin. Clin Exp Immunol. 1974;18:73-9.

Faldyna M, Levá L, Knotigová P, Toman M. Lymphocyte subsets in peripheral blood of dogs-a flow cytometric study. Vet Immunol Immunopathol. 2001;82:23-37.

Feezor RJ, Baker HV, Mindrinos M, Hayden D, Tannahill CL, Brownstein BH, et al. Whole blood and leukocyte RNA isolation for gene expression analyses. Physiol Genomics. 2004; 19:247-54.

Foyouzi-Youssefi R, Arnaudeau S, Borner C, Kelley WL, Tschopp J, Lew DP, et al. Bcl-2 decreases the free $\mathrm{Ca}^{2+}$ concentration within the endoplasmic reticulum. Proc Natl Acad Sci USA. 2000;97:5723-8.

Gontijo AMMC, Tice R. Teste do cometa para a detecção de dano no DNA e reparo em células individualizadas. In: Ribeiro LR, Salvadori DMF, Marques ED. Editors. Mutagênese Ambiental. Canoas: Editora da Ulbra; 2003. p. 247-79.

Green TR, Bennett SR, Nelson VM. Specificity and properties of propofol as an antioxidant free radical scavenger. Toxicol Appl Pharmacol. 1994;129:163-9. 
Hall G, Ali W. The stress response and its modification by regional anaesthesia. Anaesthesia. 1998;53:10-2.

Hamaya Y, Takeda T, Dohi S, Nakashima S, Nozawa Y. The effects of pentobarbital, isoflurane, and propofol on immediate-early gene expression in the vital organs of the rat. Anesth Analg. 2000;90:1177-83.

Harfe BD, Jinks-Robertson S. DNA mismatch repair and genetic instability. Annu Rev Genet. 2000;34:359-99.

Hartwell LH, Weinert TA. Checkpoints: controls that ensure the order of cell cycle events. Science. 1989;246:629-34.

Heijmakers JHJ. Genome maintenance mechanisms for preventing cancer. Nature. 2001;411: $366-74$.

IARC. International Agency for Research on Cancer [Internet]. Summary \& Evaluation. Lyon: IARC; 1987. Supplement 7: 93 [acesso 11 jan 2010]. Available from: http://www.inchem.org/documents/iarc/suppl7/anaesthetics vol.html.

Inada T, Yamanouchi Y, Jomura S, Sakamoto S, Takahashi M, Kambara T, et al. Effect of propofol and isoflurane anaesthesia on the immune response to surgery. Anaesthesia. 2004;49:954-59.

Jaloszynski P, Kujawski M, Wasowicz M, Szulc R, Szyfter K. Genotoxicity of inhalation anesthetics halothane and isoflurane in human lymphocytes studied in vitro using the comet assay. Mutat Res. 1999;439:199-206.

Jamnicki-Abegg M, Weihrauch D, Pagel PS, Kersten JR, Bosnjak ZJ, Warltier DC, et al. Isoflurane inhibits cardiac myocyte apoptosis during oxidative and inflammatory stress by activating Akt and enhancing Bcl-2 expression. Anesthesiology. 2005;103:1006-14. 
Janssen K, Schlink K, Gotte W, Hippler B, Kaina B, Oesch F. DNA repair activity of 8oxoguanine DNA glycosylase 1 (OGG1) in human lymphocytes is not dependent on genetic polymorphism Ser326/Cys326. Mutat Res. 2001;486:207-16.

Karabiyik L, Sardas S, Polat U, Kocabas NA, Karakaya AE. Comparison of genotoxicity of sevoflurane and isoflurane in human lymphocytes studied in vivo using the comet assay. Mutat Res. 2001;492:99-107.

Karahalil B, Yagar S, Bahadir G, Durak P, Sardas S. Diazepam and propofol used as anesthetics during open-heart surgery do not cause chromosomal aberrations in peripheral blood lymphocytes. Mutat Res. 2005;581:181-6.

Kim H, Oh E, Im H, Mun J, Yang M, Khim JY, et al. Oxidative damages in the DNA, lipids, and proteins of rats exposed to isofluranes and alcohols. Toxicology. 2006;220:169-78.

Kluck RM, Bossy-Wetzel E, Green DR, Newmeyer DD. The release of cytochrome c from mitochondria: a primary site for Bcl-2 regulation of apoptosis. Science. 1997;275:1132-6.

Kondo S, Toyokuni S, Tanaka T, Hiai H, Onodera H, Kasai H, et al. Overexpression of the hOGG1 gene and high 8-hydroxy-2-deoxyguanosine (8-OHdG) lyase activity in human colorectal carcinoma: regulation mechanism of the 8-OHdG level in DNA. Clin Cancer Res. 2000;6:1394-400.

Krause TK, Jansen L, Scholz J, Bottcher H, Wappler F, Burmeister MA, et al. Propofol anesthesia in children does not induce sister chromatid exchanges in lymphocytes. Mutat Res. 2003;542:59-64.

Kundomal YR, Baden JM. Mutagenicity of inhaled anesthetics in Drosophila melanogaster. Anesthesiology. 1985;62:305-9.

Kurosawa S, Kato M, Matsuoka H, Murakami M, Hashimoto Y. Direct induction of apoptosis of murine thymocytes and splenic $\mathrm{T}$ cells by volatile anesthetics in vitro. Anesthesiology. 1999;91 suppl 3A: A461. 
Kurosawa S, Kato M. Anesthetics, immune cells, and immune responses. J Anesth. 2008;22:263-77.

Lei YC, Hwang SJ, Chang CC, Kuo HW, Luo JC, Chang MJ, et al. Effects on sister chromatid exchange frequency of polymorphisms in DNA repair gene XRCC1 in smokers. Mutat Res. 2002;519:93-101.

Martin Jr JL, Njoku DB. Metabolism and toxicity of inhaled anesthetics. In: Miller RD, editor. Miller's Anesthesia. 6th ed. Pensilvânia: Elsevier; 2005a. p. 238.

Martin Jr JL, Njoku DB. Metabolism and toxicity of inhaled anesthetics. In: Miller RD, editor. Miller's Anesthesia. 6th ed. Pensilvânia: Elsevier; 2005b. p. 262.

Matsuoka H, Kurosawa S, Horinouchi T, Kato M, Hashimoto Y. Inhalation anesthetics induce apoptosis in normal peripheral lymphocytes in vitro. Anesthesiology. 2001;95:467-72.

Mo J, Xia Y, Wade TJ, Schmitt M, Le XC, Dang R, et al. Chronic arsenic exposure and oxidative stress: OGGlexpression and arsenic exposure, nail selenium, and skin hyperkeratosis in Inner Mongolia. Environ Health Perspect. 2006;114:835-41.

Mohrenweiser HW, Carrano AV, Fertitta A, Perry B, Thompson LH, Tucker JD, et al. Refined mapping on the three DNA repair genes, ERCC1, ERCC2 and XRCC1, on human chromosome 19. Cytogenet Cell Genet. 1989;52:11-4.

Nicholson DW, Thornberry NA. Caspases: killer proteases. Trends Biochem Sci. 1997;22:299-306.

Oka M, Hirazawa K, Yamamoto K, Iizuka N, Hazama S, Suzuki T, et al. Induction of Fasmediated apoptosis on circulating lymphocytes by surgical stress. Ann Surg. 1996;223:43440. 
Olive PL. Cell proliferation as a requirement for development of contact effect in Chinese hamster V79 steroids. Radiat Res. 1989;117:79-92.

Ostling O, Johanson KJ. Microeletroforetic study of radiation-induced DNA damages in individual mamallian cells. Biochem Biophys Res Commun. 1984;123:291-8.

Pan JZ, Wei H, Hecker JG, Tobias JW, Eckenhoff RG, Eckenhoff MF. Rat brain DNA transcript profile of halothane and isoflurane exposure. Pharmacogenet Genomics. 2006;16:171-82.

Peng T, Shen HM, Liu ZM, Yan LN, Peng MH, Li LQ, et al. Oxidative DNA damage in peripheral leukocytes and its association with expression and polymorphisms of hOGG1:A study of adolescents in a high risk region for hepatocellular carcinoma in China. World $\mathrm{J}$ Gastroenterol. 2003;9:2186-93.

Raff M. Cell suicide for beginners. Nature. 1998;396:119-22.

Ranganath RM, Nagashree NR. Role of programmed cell death in development. Int Rev Cytol. 2001;202:159-242.

Rydberg B, Johanson KJ. Estimation of DNA strand breaks in single mammalian cells. In: Hanwalt PC, Friedberg EC, editors. DNA repair mechanism. New York: Academic Press; 1978. p. $465-8$.

Sakamoto A, Imai JI, Nishikawa A, Honma R, Ito E, Yanagisawa Y, et al. Influence of inhalational anesthesia assessed by comprehensive gene expression profiling. Gene. 2005;356:39-48.

Salo M, Pirttikangas CO, Pulkki K. The effect of propofol emulsion and thiopentone on T helper cell type-1/type-2 balance in vitro. Anaesthesia. 1997;52:341-4. 
Sardas S, Aygun N, Gamli M, Unal Y, Unal N, Berk N, et al. Use of alkaline comet assay (single cell gel electrophoresis technique) to detect DNA damages in lymphocytes ofoperating room personnel occupationally exposed to anaesthetic gases. Mutat Res. 1998a; 418:93-100.

Sardas S, Karabiyik L, Aygun N, Karakaya AE. DNA damage evaluated by the alkaline comet assay in lymphocytes of humans anaesthetized with isoflurane. Mutat Res. $1998 b ; 418: 1-6$.

Sayin MM, Ozatamer O, Tasoz R, Kilinc K, Unal N. Propofol attenuates myocardial lipid peroxidation during coronary artery bypass grafting surgery. Br J Anaesth. 2002;89:242-6.

Shafer A, Doze VA, Shafer SL, White PF. Pharmacokinetics and pharmacodynamics of propofol infusions during general anesthesia. Anesthesiology. 1988;69:348-56.

Simons P, Cockshott I, Douglas E. Blood concentrations, metabolism and elimination after a subanesthetic intra-venous dose of (14) C-propofol (Diprivan) to male volunteers. Postgrad Med J. 1985;61:64.

Singh NP, Mccoy MT, Tice RR, Schneider EL. A simple technique for quantitation of low levels of DNA damage in individual cells. Exp Cell Res. 1988;175:184-91.

Sudprasert W, Navasumrit P, Ruchirawat M. Effects of low-dose gamma radiation on DNA damage, chromosomal aberration and expression of repair genes in human blood cells. Int $\mathbf{J}$ Hyg Environ Health. 2006;209:503-11.

Sylla P, Nihalani A, Whelan RL. Microarray analysis of the differential effects of open and laparoscopic surgery on murine splenic T-cells. Surgery. 2006;139:92-103.

Szyfter K, Szulc R, Mikstacki A, Stachecki I, Rydzanicz M, Jaloszynski P. Genotoxicity of inhalation anaesthetics: DNA lesions generated by sevoflurane in vitro and in vivo. J Appl Genet. 2004;45:369-74. 
Tice RR. The single cell/gel Comet Assay: a microgel electrophoretic technique for detection of DNA damage and repair in individuals cells. In: Phillips $\mathrm{DH}$, Venit S, editors. Environmental and molecular mutagenesis. Oxford: UK Bios Scientific Publishers; 1995. p. $315-33$.

Tice RR, Agurell E, Anderson D, Burlinson B, Hartmann A, Kobayashi H, et al. Single cell gel/comet assay: guidelines for in vitro and in vivo genetic toxicology testing. Environ Mol Mutagen. 2000;35:206-21.

Tsuchiya M, Asada A, Kasahara E, Sato EF, Shindo M, Inoue M. Antioxidant protection of propofol and its recycling in erythrocyte membranes. Am J Respir Crit Care Med. 2002;165:54-60.

Van Engeland M, Nieland LJ, Ramaekers FC, Schutte B, Reutelingsperger CP. Annexin Vaffinity assay: a review on an apoptosis detection system based on phosphatidylserine exposure. Cytometry. 1998;31:1-9.

Wei H, Liang G, Yang H, Wang Q, Hawkins B, Madesh M, et al. The common inhalational anesthetic isoflurane induces apoptosis via activation of inositol 1,4,5-trisphosphate receptors. Anesthesiology. 2008;108:251-60.

Whitney AR, Diehn M, Popper SJ, Alizadeh AA, Boldrick JC, Relman DA, et al. Individuality and variation in gene expression patterns in human blood. Proc Natl Acad Sci USA. 2003;100:1896-901.

Wise-Faberowski L, Raizada MK, Sumners C. Oxygen and glucose deprivation-induced neuronal apoptosis is attenuated by halothane and isoflurane. Anest Analg. 2001; 93:1281-7.

Xie Z, Dong Y, Maeda U, Alfille P, Culley DJ, Crosby G, et al. The common inhalation anesthetic isoflurane induces apoptosis and increases amyloid beta protein levels. Anesthesiology. 2006;104:988-94. 
Yamada R, Tsuchida S, Hara Y, Tagawa M, Ogawa R. Apoptotic lymphocytes induced by surgical trauma in dogs. J Anesth. 2002;16:131-7.

Yu J, Mallon MA, Zhang W, Freimuth RR, Marsh S, Watson MA, et al. DNA repair pathway profiling and microsatellite instability in colorectal cancer. Clin Cancer Res. 2006;12:510411.

Zhou F, Zhang W, Wei Y, Zhou D, Su Z, Meng X, et al. The changes of oxidative stress and human 8-hydroxyguanine glycosylase 1 gene expression in depressive patients with acute leukemia. Leuk Res. 2007; 31:387-93.

Zhou T, Chou J, Watkins PB, Kaufmann WK. Toxicogenomics: transcription profiling for toxicology assessment. EXS. 2009;99:325-66. 


\section{QUESTIONÁRIO}

Potencial toxicogenômico e citotóxico dos anestésicos propofol e isoflurano em indivíduos submetidos a procedimentos cirúrgicos

Registro hospitalar do paciente.

Código do indivíduo no estudo:

Data

\section{I - Identificação}

01-Nome:

02-Sexo: ( ) masculino $\quad$ ( ) feminino

03-Raça: ( ) branca ( ) amarela ( ) parda ( ) negra ( ) outra:

04-Data nascimento

05-Idade:

06-Peso:

07-Altura:

08-IMC (índice de massa corpórea):

09-Origem (cidade):

10-Profissão:

\section{II - Informações gerais}

11-Considera sua alimentação saudável? ( ) sim （ ) não

12-Come frutas? ( ) $\operatorname{sim}$ ( ) não

13-Se sim, com que freqüência?

14-Come verduras? ( ) sim ( ) não

15- Se sim, com que freqüência? 
16-Come carboidratos? ( ) sim ( ) não

17-Se sim, com que freqüência?

18-Come frituras? ( ) sim ( ) não

19-Se sim, com que freqüência?

20-Faz exercícios regularmente? ( ) sim （ ) não

21-Se sim, qual tipo (musculação, caminhada, etc)?

22-Se sim, quantas vezes por semana?

23-Fuma? ( ) sim ( ) não

24-Se sim, há quanto tempo?

25-Quantos cigarros/dia?

26-Qual tipo (cachimbo, charuto, palha, papel com filtro, etc)?:

27-Já fumou? ( ) sim （ ) não

28-Há quanto tempo deixou de fumar?

29-Quantos cigarros/dia fumava?

30-Durante quanto tempo fumou?

31-Tipo:

32-Consome bebida alcoólica? ( ) sim ( ) não

33-Se sim, quanto por semana (copos)?:

34-Tipo de bebida (cachaça, cerveja, uísque, vinho, etc)?

35-Já consumiu bebida alcoólica? ( ) sim （ ) não

36-Há quanto tempo deixou de beber?

37-Consome drogas? ( ) sim （ ) não

38-Se sim, qual?

39-Há quanto tempo?

40-Tem contato com substâncias tóxicas? ( ) sim （ ) não 
41-Se sim, qual (produtos de limpeza, agrotóxicos, gasolina, tinta)?

42-Há quanto tempo?

43-Foi submetido a raio $\mathrm{X}$ recentemente (dentário ou antes da cirurgia)?

( ) $\operatorname{sim}$ ( ) não

44-Quando?

45-Sabe quantas chapas de RX foram feitas?

46- Já fez tratamento com quimioterápico ou radioterapia? ( ) sim （ ) não

47-Se sim, qual?

48-Há quanto tempo?

49-Tem alguma doença (asma, hipertensão, diabetes, hepatite, lúpus, artrite, câncer)?

( ) $\operatorname{sim}$ ( ) não

50-Qual?

51-Já teve alguma doença grave? ( ) sim （ ) não

52-Se sim, qual?

53-Há quanto tempo?

54-Passou por algum estresse ultimamente? ( ) sim ( ) não

55-Se sim, qual?

\section{III - História Médica}

56-É alérgico a algum tipo de medicamento? ( ) sim ( ) não

57-Se sim, qual?

58-Faz uso de algum tipo de medicamento (antibiótico, anti-inflamatório, analgésico, antihipertensivo, corticóide, anti-convulsivante, insulina, hipoglicemiante)?

( ) $\operatorname{sim}$ ( ) não

59-Se sim, qual (is)?

60-Frequência/dia: 
61-Faz uso de vitamina/antioxidante (complexo vitamínico)? ( ) sim ( ) não

62-Se sim, qual (is)?

63-Frequência/dia:

64-Há quanto tempo?

65-Tomou alguma medicação no último mês (remédio para pressão, antibiótico, tranqüilizantes, remédio para tirar a dor, antiácidos, anti-histamínicos, corticóides, antiinflamatórios)? ( ) sim ( ) não

66-Se sim, qual (is)?

67-Frequência/dia:

68-Há quanto tempo parou?

69- Teve alguma infecção ou inflamação no último mês? ( ) sim （ ) não

70- Se sim, qual (is)?

71- Há quanto tempo parou?

72- Está resfriado ou gripado? ( ) sim ( ) não

73-Já fez alguma cirurgia? ( ) sim （ ） não

74-Se sim, quantas?

75-Há quanto tempo foi a última?

76-Já foi submetido à anestesia? ( ) sim （ ) não

77-Se sim, sabe o tipo de anestesia (local, geral, raquídea, regional)?

78-Há quanto tempo?

79-Se sim, você sabe se é mais resistente ou sensível a algum anestésico? 
TERMO DE CONSENTIMENTO LIVRE E ESCLARECIDO

I. Identificação do paciente (RG hospitalar:

)

Nome:

Endereço:

Cidade:

\begin{tabular}{l|l|l} 
CEP: & Estado: & Telefone:
\end{tabular}

\section{Título da Pesquisa}

Potencial toxicogenômico e citotóxico dos anestésicos propofol e isoflurano em indivíduos submetidos a procedimentos cirúrgicos

Pesquisador-Responsável: Daisy Maria Fávero Salvadori, Pesquisadora do Departamento de Patologia - Faculdade de Medicina, UNESP, Botucatu - SP. Telefone (14) 38828255; e-mail: dfavero@,fmb.unesp.br

\section{Explicações do pesquisador ao paciente}

Este estudo, que será realizado em pacientes que serão submetidos às cirurgias de nariz ou ouvido tem como objetivo avaliar se os anestésicos isoflurano (via inalatória) ou propofol (via venosa), que serão utilizados na cirurgia, têm algum efeito tóxico sobre o DNA - material genético (o componente que determina suas características individuais) presente nas células do sangue. Será avaliado se esses anestésicos podem causar danos diretamente na estrutura do DNA e se podem alterar a expressão de genes, isto é, de parte do DNA responsável pela manutenção da célula sanguínea. Para checar esses efeitos, será realizado um teste que avalia a integridade do DNA e outro que permite determinar se há células mortas no sangue. Como os dois anestésicos, o isoflurano e o propofol, têm a mesma eficiência e não têm efeitos colaterais, a escolha do qual será utilizado será feita por sorteio. $\mathrm{O}$ estudo não trará danos ao paciente, pois serão utilizados anestésicos normalmente empregados em anestesias gerais (inalatória e venosa) no Hospital das Clínicas. Desta forma, solicitamos seu consentimento para que sejam coletadas 3 amostras de $15 \mathrm{ml}$ de sangue periférico: a primeira, antes da cirurgia; a segunda no final da cirurgia; e a última, um dia após a cirurgia (pósoperatório). A quantidade de sangue que será coletada não afetará sua recuperação póscirúrgica, e a quantia é muito pequena em relação ao volume total de sangue do organismo. A 
coleta será realizada por profissional experiente, e o procedimento causa apenas o desconforto da picada com risco mínimo ou quase inexistente, já que será utilizado material estéril e descartável. Será realizado, também, um questionário sobre seu estilo de vida e história médica; todas as informações são de caráter confidencial e sua identidade será preservada. $\mathrm{O}$ pesquisador responsável por este estudo, sempre que solicitado, estará à disposição para esclarecer qualquer questão relacionada à pesquisa. Além disso, o paciente, a qualquer momento, terá total liberdade de recusar ou retirar seu consentimento e sair desta pesquisa, sem que isso lhe traga qualquer tipo de prejuízo.

Os resultados do estudo serão divulgados em congressos científicos e publicados em revistas especializadas, mas sempre preservando a identidade do paciente. Ressaltamos, também, que nem os pesquisadores e nem o paciente receberão qualquer remuneração financeira para participar desta pesquisa.

\section{Consentimento Pós-Informado}

$\mathrm{Eu}$, abaixo assinado, declaro que fui esclarecido sobre o objetivo do presente estudo, sobre eventuais desconfortos que poderei sofrer, assim como sobre os benefícios que podem resultar do estudo. Concordo, portanto, em participar, na qualidade de paciente, do referido Projeto de Pesquisa, sob livre e espontânea vontade.

de de

Assinatura 